WSRC-TR-2003-00212, Rev. 0

SRT-RPP-2003-00094, Rev. 0

\title{
Waste Feed Evaporation: Physical Properties and Solubility Determination (U)
}

MAY 13, 2003

\section{SAVANNAH RIVER TECHNOLOGY CENTER}
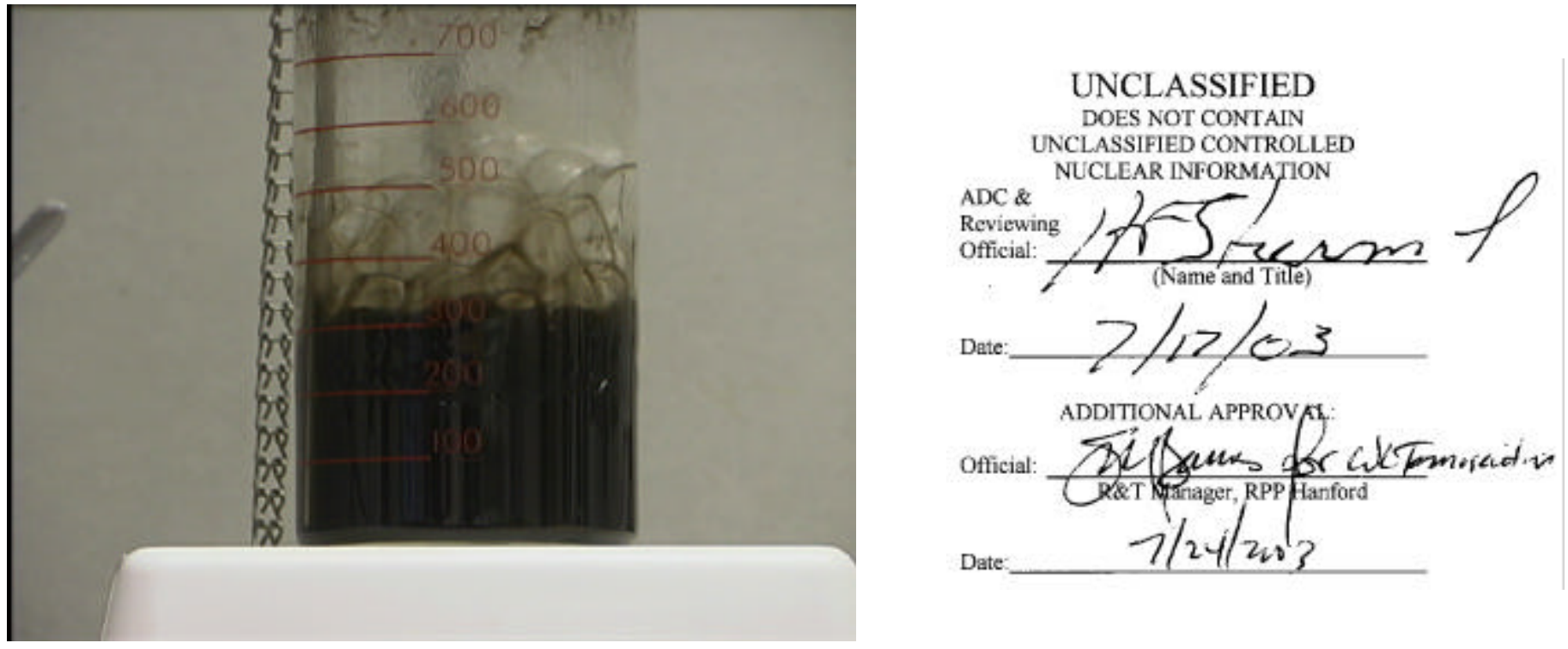

Evaporation of Envelope C UF Recycle

Westinghouse Savannah River Company

Savannah River Site

Aiken, SC 29808

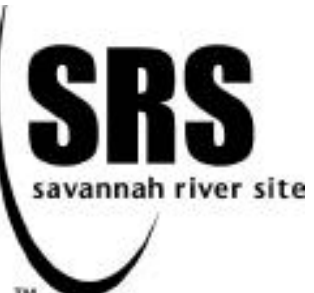


This document was prepared in conjunction with work accomplished under Contract No. DE-AC09-96SR18500 with the U. S. Department of Energy.

\section{DISCLAIMER}

This report was prepared as an account of work sponsored by an agency of the United States Government. Neither the United States Government nor any agency thereof, nor any of their employees, makes any warranty, express or implied, or assumes any legal liability or responsibility for the accuracy, completeness, or usefulness of any information, apparatus, product or process disclosed, or represents that its use would not infringe privately owned rights. Reference herein to any specific commercial product, process or service by trade name, trademark, manufacturer, or otherwise does not necessarily constitute or imply its endorsement, recommendation, or favoring by the United States Government or any agency thereof. The views and opinions of authors expressed herein do not necessarily state or reflect those of the United States Government or any agency thereof.

This report has been reproduced directly from the best available copy.

Available for sale to the public, in paper, from: U.S. Department of Commerce, National Technical Information Service, 5285 Port Royal Road, Springfield, VA 22161, phone: (800) 553-6847, fax: (703) 605-6900

email: orders@ntis.fedworld.gov

online ordering: http://www.ntis.gov/help/index.asp

Available electronically at http://www.osti.gov/bridge

Available for a processing fee to U.S. Department of Energy and its contractors, in paper, from: U.S. Department of Energy, Office of Scientific and Technical Information, P.O. Box 62, Oak Ridge, TN 37831-0062,

phone: (865)576-8401,

fax: (865)576-5728

email: $\underline{\text { reports@ adonis.osti.gov }}$ 
Key Words:

Evaporation

Submerged Bed Scrubber Recycle

Ultrafiltration Recycle

\title{
Retention:
}

Permanent

Key WTP R\&T References:

Test Specification: 24590-PTF-TSP-RT-01005, Rev 0

Test Plan: WSRC-TR-2002-00039

R\&T Focus Area: Waste Feed Evaporation

Test Scoping Statement: S90

\section{Waste Feed Evaporation: Physical Properties and Solubility Determination}

\author{
Michael E. Stone, 999-W \\ T. B. Calloway, 999-W \\ E. K. Hansen, 999-W \\ F. F. Fondeur, 773-A
}

\section{Issue Date: April 30, 2003}


This page intentionally left blank 


\section{TABLE OF CONTENTS}

LIST OF FIGURES ....................................................................................................................... VI

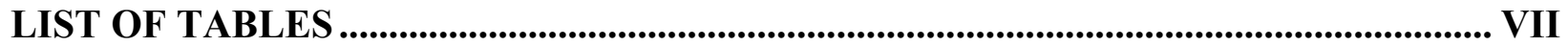

LIST OF ACRONYMS .............................................................................................................. VII

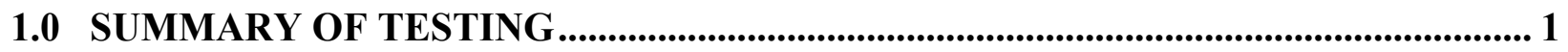

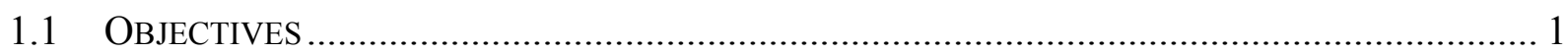

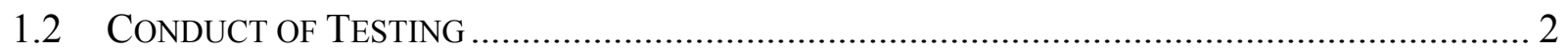

1.3 Results AND Performance Against OBJectives ………........................................... 2

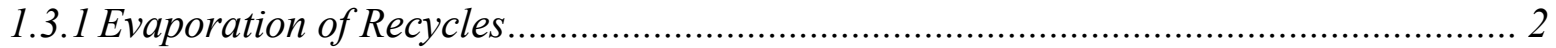

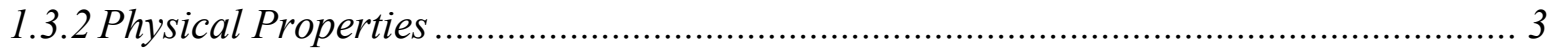

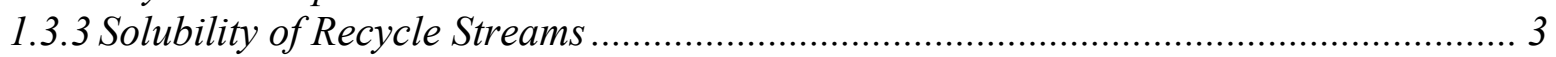

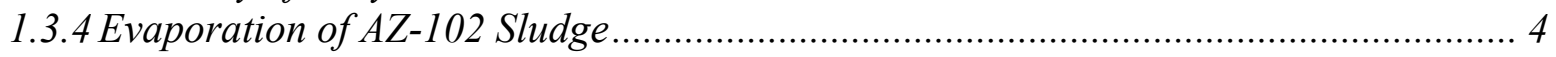

1.3.5 Fate of Mercury during Waste Feed Evaporation ................................................... 4

1.3.6 Solubility of Strontium in Waste Feed Evaporator Streams ........................................ 4

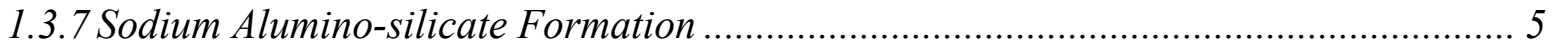

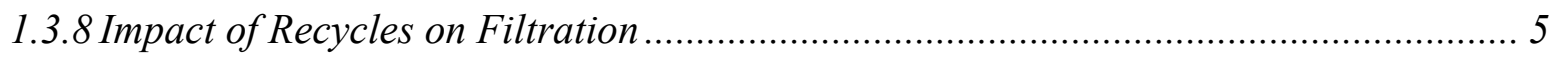

1.4 QUALITY REQUIREMENTS................................................................................ 5

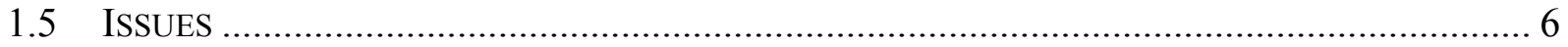

1.5.1 Gel Formation in the Blended UF Recycle Stream................................................... 6

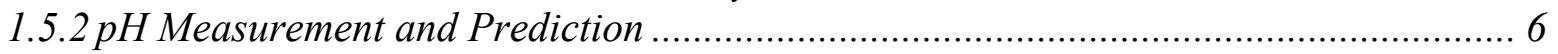

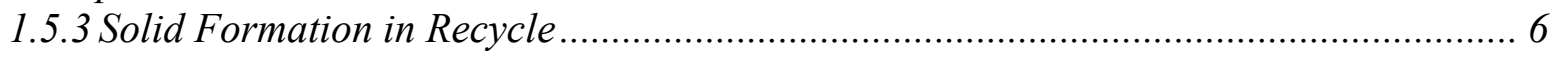

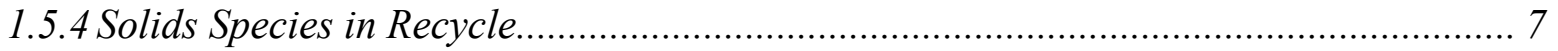

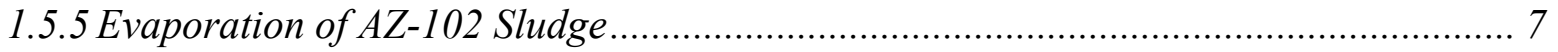

1.5.6 Impact of Recycle on Filtration.......................................................................... 7

2.0 CD/ROM ENCLOSURES......................................................................................... 7

3.0 DISCUSSION ....................................................................................................................... 7

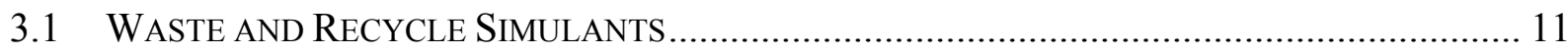

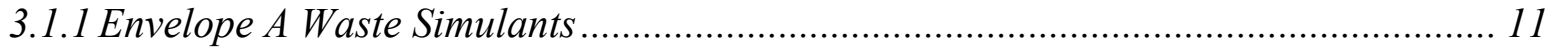

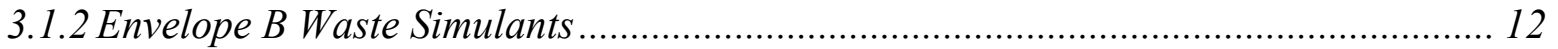

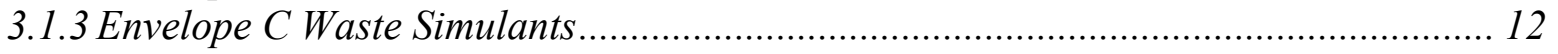

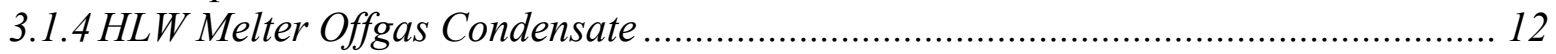

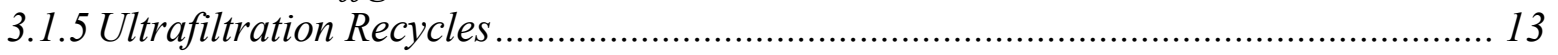

3.1.6 Other Recycles................................................................................................. 17

3.2 EVAPORATION OF HLW MELTER OfFGas CONDENSATE ……….................................... 17

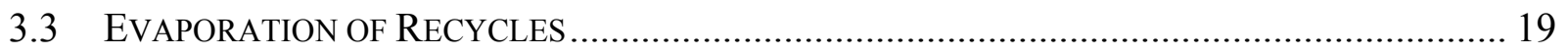

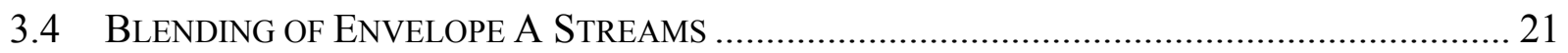

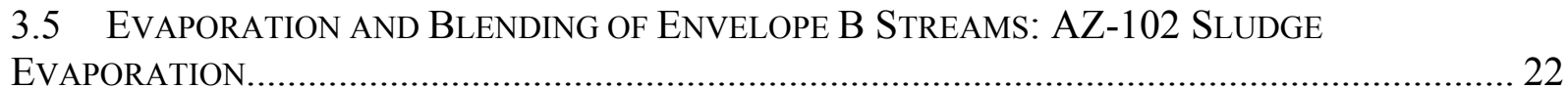

3.6 BLENDING AND PRECIPITATION OF ENVELOPE C STREAMS ........................................... 24

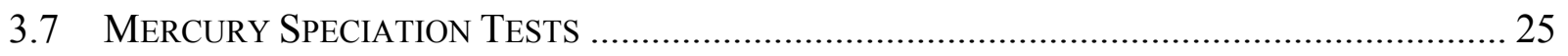


3.8 Filtration Of ENVELOPE A WaSte BLENDS............................................................... 27

3.9 BulK Solubility OF RECYCLE AND BLENDEd StREAMS ............................................... 29

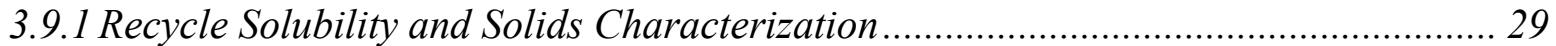

3.9.2 Waste Feed / Recycle Blend Solids Characterization ................................................ 31

3.10 SR SOLUBILITY DURING WASTE FEED EVAPORATION .................................................... 34

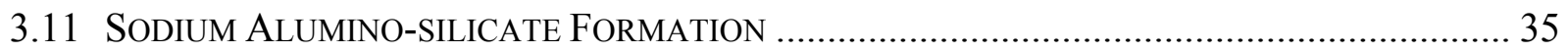

3.12 Physical Property TeSting AND InStRUmentation ................................................... 38

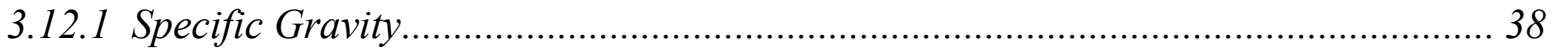

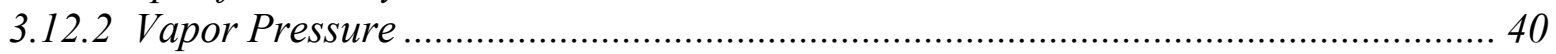

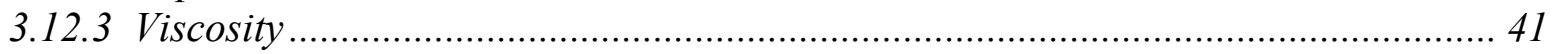

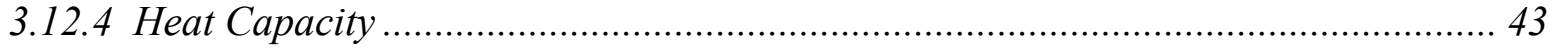

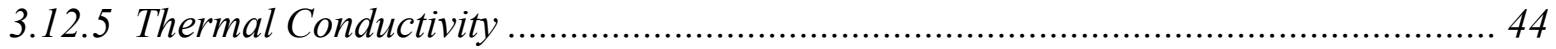

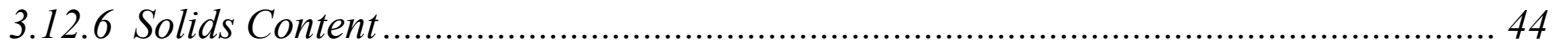

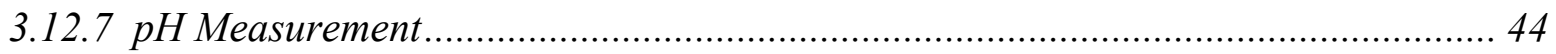

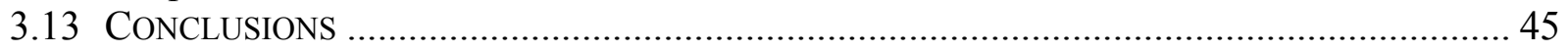

4.0 FUTURE WORK ..................................................................................................................... 45

APPENDIX A. COMPOSITION DATA …......................................................................................... 47

APPENDIX B. APPARATUS DIAGRAMS........................................................................5

APPENDIX C. PHYSICAL PROPERTY CHARTS...............................................................60

APPENDIX D. MODELING OF UF BLEND PROCESS ............................................................. 76

APPENDIX E. EVAPORATION PHOTOGRAPHS ................................................................ 80

\section{LIST OF FIGURES}

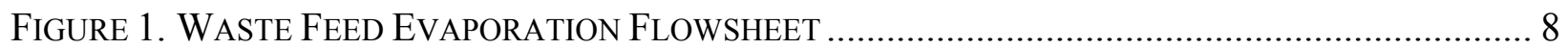

FIGURE 2. HYPOTHETICAL EVAPORATION ENDPOINT DETERMINATION........................................... 9

FiguRE 3. HYPOTHETICAL EVAPORATION ENDPOINT DETERMINATIONS WITH 3M AND 4M FEEDS

FigURE 4. FoRMATION OF GELS IN ENVELOPE A UF RECYCLES ................................................. 16

FiguRE 5. UF RECYCLES WITHOUT ACID ClEANING Solution AdDITION..................................... 16

FIGURE 6. EVAPORATION ENDPOINT DETERMINATION FOR MOGC …...................................... 18

FiguRE 7. EVAPORATION OF MELTER OfFGas Condensate .................................................... 19

Figure 8. SPlatTER DURING EVAPORATION OF AZ-102 w/ 33\% UF ReCYClE ............................ 23

Figure 9. Viscosity AND Yield StResS OF AZ-102-RECYCLE BLENDS AT 5M NA AT $25^{\circ} \mathrm{C} . . . .23$

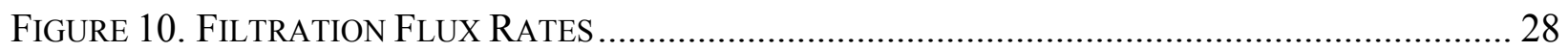

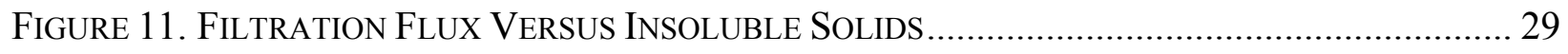

FigURE 12. NAS FoRMATION IN ENVELOPE A WASTE / RECYCLE BLENDS ................................... 37

FigURE 13. ANTON PAAR DMA-4500 AND GRABNER MiNIVAP VOC INSTRUMENTS .................... 38

FigURE 14. EXPECTED OPERATING TEMPERATURE OF WASTE FEED EVAPORATOR ........................ 41

FiguRE 15. VAPOR PRESSURE OF AZ-102 EVAPORATOR CONCENTRATES ................................... 41 


\section{LIST OF TABLES}

TABle 1. EnVelope A Simulant Matrix. 11

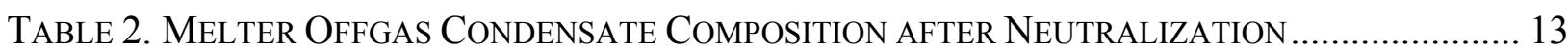

Table 3. Caustic Additions to Mitigate Gel Formation in UF Recycle .............................. 17

TABLE 4. EVAPORATION PARAMETERS FOR MOGC ………………………............................... 19

TABLE 5. RUN PARAMETERS FOR RECYCLE EVAPORATIONS ........................................................ 20

TABle 6. Parameters For Blending OF 7M ENVElope A WASTE FeEd AND RECYCleS. ........ 21

TABLE 7. PARAMETERS FOR BLENDING OF 5.2M ENVELOPE A WASTE FEED AND RECYCLES. ..... 21

TABLE 8. EVAPORATION PARAMETERS FOR ENVELOPE B BLENDS .............................................. 22

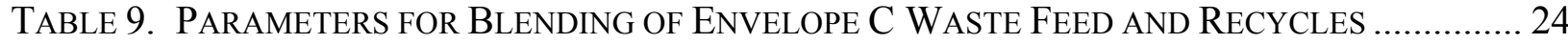

TABLE 10. AMOUNT OF WATER AdDED TO ENVELOPE C BLENDS .............................................. 25

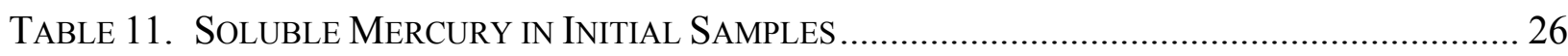

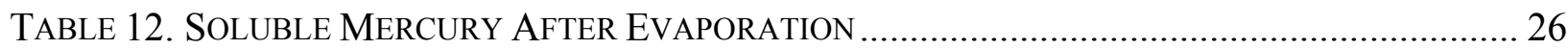

TABLE 13. MERCURY IN EVAPORATOR OFFGAS SYSTEM............................................................. 26

TABLE 14. PARAMETERS AND RESULTS FOR FILTRATION TESTS .................................................... 28

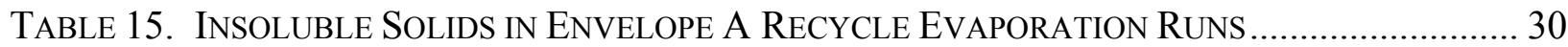

TABLE 16. INSOLUBLE SOLIDS IN ENVELOPE B RECYCLE EVAPORATION RUNS ................................ 31

TABLE 17. INSOLUBLE SOLIDS IN ENVELOPE C RECYCLE EVAPORATION RunS ............................... 31

TABLE 18. SOLIDS IN WASTE FEED - RECYCLE BLENDS: ENVELOPE A............................................ 32

TABLE 19. SolidS IN WASTE FEED - RECYCLE BLENDS: ENVELOPE B ............................................ 33

TABLE 20. SOLIDS IN WASTE FEED - RECYCLE BLENDS: ENVELOPE C.......................................... 33

TABle 21. Soluble Strontium IN ENVELOPE C UF ReCYCLE ................................................... 34

Table 22. Soluble Strontium UF Recycle with 50\% Melter OfFGas Condensate ......... 34

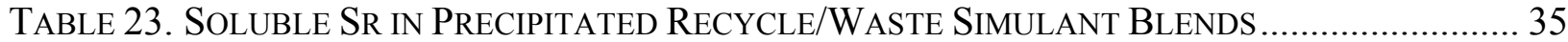

TABle 24. Parameters for ENVELoPe A ANd B SPeCific Gravity Correlations .................. 39

TABLE 25. PARAMETERS FOR ENVELOPE C SPECIFIC GRAVITY CORRELATIONS ............................. 39

TABLE 26. PARAMETERS FOR VISCOSITY CORRELATIONS AS A FUNCTION OF SODIUM

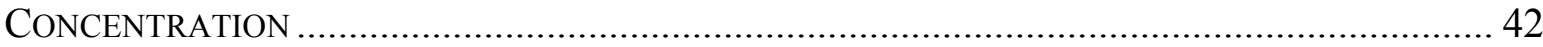

TABLE 27. PARAMETERS FOR VISCOSITY CORRELATIONS AS A FUNCTION OF TEMPERATURE ........ 43

TABLE 28. PARAMETERS FOR HEAT CAPACITY CORRELATIONS .......................................................... 43

\section{LIST OF ACRONYMS}

ADS
DOE
HEME
HLW
ICP-ES
LAW
MOGC
NAS
PNNL
RPP-WTP
SBS

Analytical Development Section

Department of Energy

High Efficiency Moisture Eliminator

High Level Waste

Inductively Coupled Plasma-Emission Spectroscopy

Low Activity Waste

Melter Offgas Condensate

Sodium Aluminosilicate

Pacific Northwest National Laboratory

River Protection Project-Waste Treatment Plant

Submerged Bed Scrubber 
SRTC Savannah River Technology Center

Sr/TRU Strontium/Transuranic

UF

Ultrafiltration

VSL

Vitrious State Laboratory

WESP

Wet ElectroStatic Plate

WSRC

Westinghouse Savannah River Company

XRD

X-Ray Diffraction

\section{LIST OF TABLES IN APPENDIX A}

TABle A- 1. TARget Compositions of EnVELoPe A AND B UF ReCyCle StREAMS.................. 47

TABLE A- 2. TARGET CoMPOSITIONS OF ENVELOPE A RECYCLES …………………………........ 48

TABLE A- 3. TARGET COMPOSITIONS OF ENVELOPE B RECYCLE .................................................... 49

TABLE A- 4. CoMPosition of ENVELOPE C RECYCLE.............................................................. 50

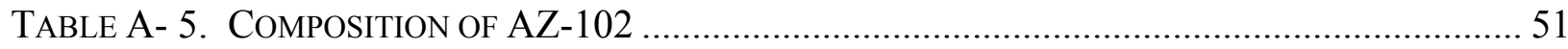

TABle A- 6. Composition of EnVElope C WaSte SimulantS.................................................. 52

TABLE A- 7. Compositions of OLI VALIDATION PoINTS For ENVELOPE A.................................. 53

\section{LIST OF FIGURES IN APPENDIX B}

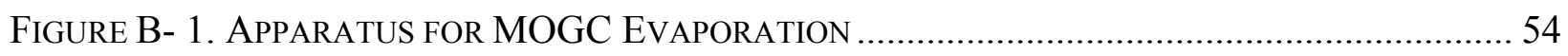

Figure B- 2. APPARATUS For ENVELOPE A AND C RECYCLE EVAPORATION ……………….........55

FIGURE B- 3. APPARATUS FOR ENVELOPE B EVAPORATIONS ....................................................... 56

Figure B- 4. APPARATUS For EVAPORATION RUNS WITH MERCURY SPIKES ................................5 57

Figure B- 5. ApPARATUS For CROSS-Flow FILTRATION TESTS .................................................5 58

Figure B- 6. APPARATUS For ENVELOPE C PRECIPITATIONS ……………................................... 59

\section{LIST OF FIGURES IN APPENDIX C}

Figure C- 1. EnVELOPE A ReCYCle SPeCIFIC GRAVITY @ $25^{\circ} \mathrm{C}$................................................. 60

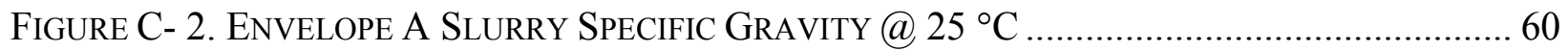

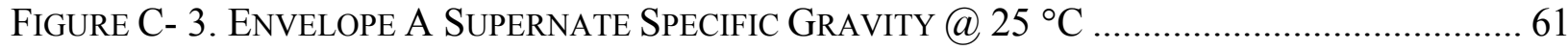

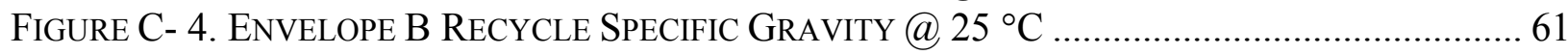

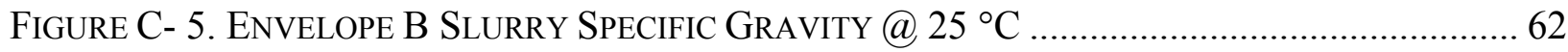

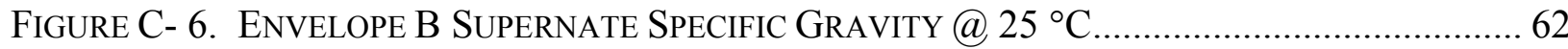

Figure C- 7. ENVELOPE C ReCYCLE SPECIFIC GRAVITY @ $25^{\circ} \mathrm{C}$.................................................. 63

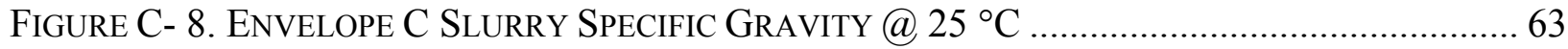

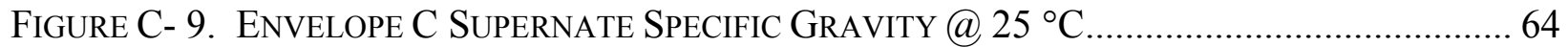

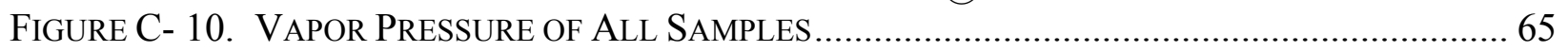

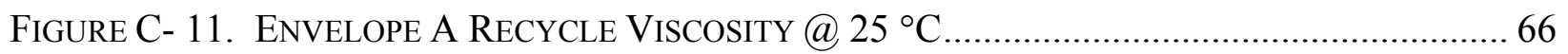

FigURE C- 12. ENVELOPE A Viscosity @ $25^{\circ} \mathrm{C}$....................................................................... 66 


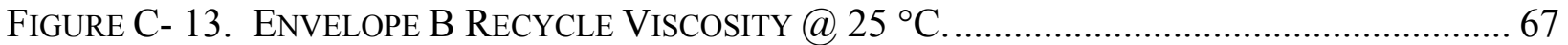

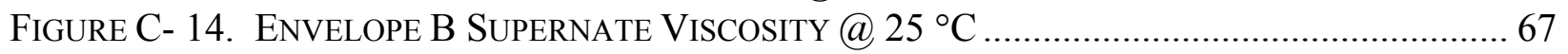

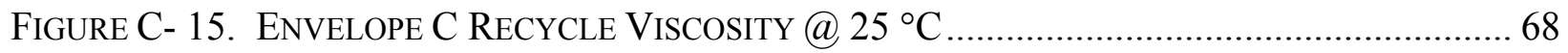

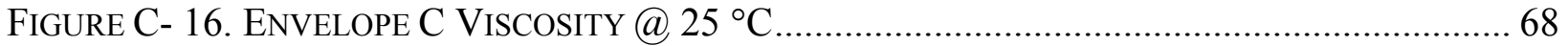

FiguRE C- 17. ENVELOPE A VisCOSITY AS A FUNCTION OF TEMPERATURE ..................................69

FigurE C- 18. ENVELOPE B VisCOSITY AS A FunCTION OF TEMPERATURE ................................. 69

Figure C- 19. ENVELOPE C Viscosity AS A FunCTION OF TEMPERATURE ............................... 70

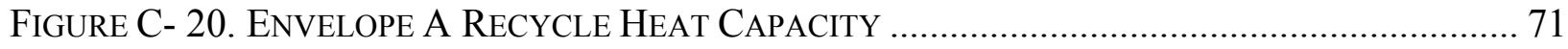

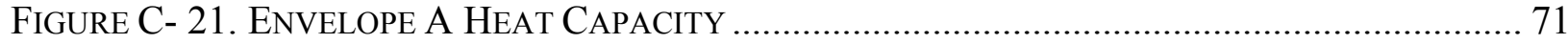

Figure C- 22. ENVELOPE B RECYCLE HEAT CAPACITY......................................................... 72

Figure C- 23. ENVELOPE B HeAt CAPACITY ….................................................................... 72

FIGURE C- 24. ENVELOPE C RECYCLE HEAT CAPACITY ........................................................... 73

Figure C- 25. ENVELOPE C HEAT CAPACITY ..................................................................... 73

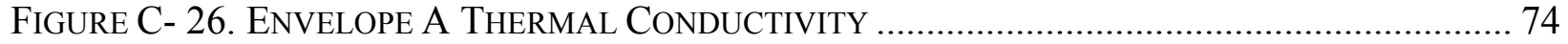

FIGURE C- 27. ENVELOPE B THERMAL CONDUCTIVITY ......................................................... 74

Figure C- 28. ENVELOPE C ThERMAL CONDUCTIVITY …....................................................... 75

\section{LIST OF FIGURES IN APPENDIX D}

Figure D- 1. Block Diagram of UF Blend Model ............................................................... 77

FIGURE D- 2. RESULTS FOR OLI PH PREDICTIONS VERSUS EXPERIMENTAL RESULTS.................... 79

\section{LIST OF TABLES IN APPENDIX D}

Table D- 1. Charge Balanced InPUt Streams .............................................................. 76

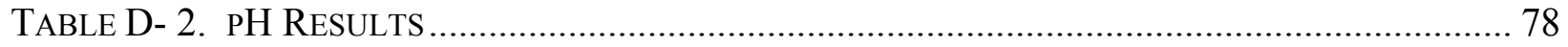

TABLE D- 3. Soluble/InSOLUbLe Ratio ReSults ................................................................... 79

\section{LIST OF FIGURES IN APPENDIX E}

Figure E- 1. EVAPORATION OF ENVELOPE A UF RECYCLE...................................................... 80

FIGURE E- 2. EVAPORATION OF AZ-102 w/ 3.5\% INITIAL INSOLUBLE SOLIDS .......................... 80

FIGURE E- 3. EVAPORATION OF ENVELOPE C UF RECYCLE ...................................................... 81 


\subsection{Summary of Testing}

\subsection{Objectives}

The overall objective of this task was to characterize the evaporation of recycles and waste feed (when required) in the waste feed evaporator and to determine the impact of blending concentrated recycle with the waste feed when the waste feed bypasses the evaporator for Envelopes A, B, and C.

The specific objectives for this task as outlined in the Task Technical and Quality Assurance Plan ${ }^{1}$ were:

1. Characterize the evaporation of recycles and blends of waste feed with recycles when the waste feed is less than 5 molar sodium. The evaporator feeds will be concentrated to target a specific gravity of 1.22 in the aqueous portion of the Ultrafiltration feed (approximately $5 \mathrm{M}$ $\mathrm{Na}$ ). Chemical and physical analysis of the recycles and waste feed blends will be conducted before and after evaporation.

2. Determine the impact of mixing concentrated recycles with the waste feed when the waste feed is greater than 5 molar sodium. The evaporation process and blending will be conducted to target a specific gravity of 1.22 in the aqueous portion (approximately $5 \mathrm{M} \mathrm{Na}$ ) after blending. Chemical and physical analysis of the recycles and blends will be conducted before and after blending.

3. Develop solubility data for the various waste feed evaporator concentrate solutions and/or Ultrafiltration feed solutions. In these tests, SRTC will determine the solubilities of simulated waste feed and concentrated recycle blends as a function of temperature and concentration of major analytes.

4. Develop physical property data for various Ultrafiltration feed solutions as a function of sodium concentration and temperature. In these tests, SRTC will measure a variety of physical properties using standard analytical techniques.

5. Evaluation of the foaming tendencies of waste feed and recycle simulants under WTP evaporator conditions.

6. Evaluation of the ratio of insoluble to soluble strontium concentrations during evaporation.

7. Evaluation of the filterability of blended LAW/concentrated recycles.

8. Evaluation of the speciation of mercury during the waste feed evaporation process by determining the amount of soluble and insoluble mercury before and after evaporation as well as the amount of mercury that is evaporated into the offgas system.

9. Determine the potential for sodium alumino-silicate formation during waste feed evaporation.

10. Provide data for task S89: Waste Feed Evaporation Modeling.

${ }^{1}$ Stone, M. E., etc. Task Technical and Quality Assurance Plan for Waste Feed: Simulant Evaporation and Physical Properties Determination. WSRC-TR-2002-00039, January 14, 2002. 


\subsection{Conduct of Testing}

The waste feed to the Waste Treatment Plant (WTP) will be blended with recycles prior to the Ultrafiltration process. If the waste feed is dilute, it will be evaporated in the waste feed evaporator after blending with the recycles to target of supernate specific gravity of 1.22 after evaporation. If the waste feed is concentrated so that its supernate $\mathrm{SpG}$ is above 1.22 when received by the WTP, it will be blended with recycles after the recycles are evaporated in the waste feed evaporator. The recycles would be concentrated as required to target a supernate specific gravity of 1.22 after blending with the waste feed.

Testing was conducted on non-radioactive simulants of the waste feed evaporator feed and postevaporation blends. Testing was conducted on recycle without waste feed and on blends of recycle with the waste feed. When the waste feed was greater than 5M sodium, the blending of feed and recycle was performed post-evaporation and the recycle was concentrated as required to target a blended stream with a supernate specific gravity of 1.22 . When the waste feed was dilute ( $<5 \mathrm{M}$ sodium), the blending was performed prior to evaporation and the combined stream was concentrated by evaporation to $5 \mathrm{M}$ sodium. Testing was conducted for Envelopes A,B, and C waste feeds.

The physical properties (density, vapor pressure, heat capacity, thermal conductivity, and viscosity) of the feed to the evaporator and the evaporator bottoms was measured as a function of temperature and sodium concentration. In addition, the weight $\%$ solids of the streams was measured to determine if additional solids were precipitated during the evaporation or blending processes and the solids were characterized by X-ray diffraction (XRD). In particular, the XRD spectrum was analyzed to determine if any sodium alumino-silicates were present.

During testing of Envelope $\mathrm{C}$ samples, the amount of soluble strontium was tracked to determine the impact of evaporation on the solubility of strontium. Mercury was added to selected runs and the amount of soluble mercury was measured before and after evaporation. The evaporator condensate was measured for mercury and whether or not mercury passed through the condensor system was determined.

The impact of the recycles on the subsequent filtration was measured by a lab-scale cross-flow filter system. The initial permeate rate for two Envelope A simulants was measured with and without the addition of recycle.

\subsection{Results and Performance Against Objectives}

\subsubsection{Evaporation of Recycles}

Recycle streams and waste feeds blended with recycle were evaporated under vacuum conditions at approximately $1 / 10^{\text {th }}$ of the design basis flux rate with very little foaming noted during the runs. All runs with the bench scale evaporator had problems with "bumping", defined as the solution superheating slightly and then releasing large amounts of vapor which throws the solution in the vessel upwards. The bumping is believed to be a system of the scale of the 
WSRC-TR-2003-00212, Rev. 0

SRT-RPP-2003-00094, Rev. 0

laboratory tests and should not occur in larger vessels. These results accomplish Objectives 1 and 5.

\subsubsection{Physical Properties}

Data was collected for density, vapor pressure, heat capacity, viscosity, and thermal conductivity as a function of sodium concentration and temperature.

The temperature impact on density was found to be similar to water and regressions for each envelope were performed that are independent of temperature by converting the data to specific gravity. Correlations of specific gravity as a function of sodium concentration were developed for recycle and for the combined data sets of waste feeds, recycles, and waste/recycle blended streams. Separate correlations were developed for each envelope.

Vapor pressure was regressed as a function of sodium concentration and temperature for the combined data sets of waste feeds, recycles, and blended streams. Separate correlations for each waste envelope were not developed; one correlation was developed for all envelopes since the correlation fit was acceptable with all envelopes combined.

Heat capacity was found to be independent of temperature over the range tested. Correlations were developed for recycle only and for the combined data sets of waste feeds, recycles, and blended streams for each envelope.

Viscosity was found to be a function of temperature and sodium concentration. Correlations were developed as a function of sodium concentration for recycle only and for the combined data sets of waste feeds, recycles, and blended streams for each envelope at 25 Celsius. Correlations were developed at the expected blend composition as a function of temperature for each envelope.

Thermal conductivity data indicated a significant amount of scatter and regressions were not attempted. The data indicated that the deviation of the thermal conductivity from water was not significant as the scatter was nominally centered around the thermal conductivity of water.

These results accomplish Objectives 2 and 4.

\subsubsection{Solubility of Recycle Streams}

Both the melter offgas condensate and the UF recycle contained solids prior to evaporation. The solids precipitated during addition of the acid cleaning solution to the UF recycle and from the undissolved solids in the melter offgas condensate. The precipitated solids formed gels when the $\mathrm{pH}$ of the UF recycle stream was reduced below a $\mathrm{pH}$ of 12 during the acid addition, therefore sodium hydroxide was used to adjust the $\mathrm{pH}$ of the blended UF recycle above 13 .

For Envelopes B and C, evaporation did not impact the amount of solids precipitated from the solutions up to the targeted sodium concentrations for evaporation. Evaporation of Envelope A recycle resulted in some precipitation of solids with the concentrated stream $(\sim 5 \mathrm{M} \mathrm{Na})$ 
containing up to $4 \mathrm{wt} \%$ solids. The precipitated solids were analyzed by XRD and contained thermonatrite $\left(\mathrm{Na}_{2} \mathrm{CO}_{3} \cdot \mathrm{H}_{2} \mathrm{O}\right)$, natrophosphate $\left(\mathrm{Na}_{7} \mathrm{~F}\left(\mathrm{PO}_{4}\right)_{2} \cdot 19 \mathrm{H}_{2} \mathrm{O}\right)$, natroxalate $\left(\mathrm{Na}_{2} \mathrm{C}_{2} \mathrm{O}_{4}\right)$, sodium nitrate $\left(\mathrm{NaNO}_{3}\right)$, sodium nitrite $\left(\mathrm{NaNO}_{2}\right)$ and lithium aluminum carbonate hydroxide hydrate $\left(\left(\mathrm{Al}_{2} \mathrm{Li}(\mathrm{OH})_{6}\right)_{2} \mathrm{CO}_{3} \cdot \mathrm{xH}_{2} \mathrm{O}\right.$ in addition to the gibbsite and bayerite $\left(\mathrm{Al}(\mathrm{OH})_{3}\right)$ present prior to evaporation. These results accomplish Objective 3 .

\subsubsection{Evaporation of AZ-102 Sludge}

Evaporation tests were conducted to determine the behavior of AZ-102 sludge in the waste feed evaporator. AZ-102 was evaporated to $5 \mathrm{M} \mathrm{Na}$ with and without recycles added. Very little foaming was noted during the runs, which were conducted at approximately $1 / 10^{\text {th }}$ of the design basis flux rate. Severe bumping occurred during the latter portion of several runs when the insoluble solids concentration exceeded $7 \mathrm{wt} \%$ solids. Consistency and yield stress were shown to increase significantly past $7 \mathrm{wt} \%$ solids. Consistency was $4-6 \mathrm{cP}$ below $7 \%$ solids and $12 \mathrm{cP}$

at $9 \%$ solids while yield stress went from 3 dynes $/ \mathrm{cm}^{2}$ at $7 \%$ solids to 27 dynes $/ \mathrm{cm}^{2}$ at $9 \%$ solids. These results accomplish Objective 1.

\subsubsection{Fate of Mercury during Waste Feed Evaporation}

Tests were conducted to determine the fate of mercury during waste feed evaporation. Mercuric nitrate was spiked into Envelope A waste simulants diluted to $2.7 \mathrm{M}$ sodium to target $200 \mathrm{ppm}$ $\mathrm{Hg}$. The simulants were then evaporated to $5 \mathrm{M}$ sodium. No mercury was noted in the offgas condensate or the non-condensable gases and no elemental mercury hold up was noted on the glassware utilized for the offgas system. The tests indicate that mercury will remain in the evaporator bottoms during the evaporation process. Approximately one-third of the mercury was soluble prior to evaporation while one-half to two-thirds was soluble after evaporation. Mercury was also added to a sample of AZ-102, with less than $10 \%$ soluble mercury. These results accomplish Objective 8 .

\subsubsection{Solubility of Strontium in Waste Feed Evaporator Streams}

The amount of soluble strontium was measured in each of the Envelope $\mathrm{C}$ recycle streams, after blending of the recycles, and after concentration in the waste feed evaporator. The primary source of strontium was the acid cleaning solution which contained $0.25 \mathrm{M}$ soluble strontium. The blending of the acid cleaning solution with the wash solution led to precipitation of the strontium and left soluble strontium levels similar to the amounts in the first wash solution (8.4E-5M soluble $\mathrm{Sr}$ in wash solution). Evaporation of the recycle led to some amount of strontium dissolution, but the levels of soluble strontium after evaporation remained at or below the levels in the first wash solution.

Levels of soluble strontium after precipitation were measured for AN-102, AN-107 and blends of the waste feeds with concentrated recycles. The values of soluble strontium for the waste only compared well with previous studies and the runs with recycle indicated similar levels of soluble strontium after precipitation. Addition of concentrated recycle to the precipitation process did not impact the levels of soluble strontium that would be fed to the filtration process. These results accomplish Objective 6 . 


\subsubsection{Sodium Alumino-silicate Formation}

NAS formation was not noted in the recycle feed to the waste feed evaporator or in the concentrated recycle after evaporation. Although NAS solids were not noted, other solids such as gibbsite and bayerite were present before and after evaporation which could lead to scaling and fouling of the evaporator.

Sodium alumino-silicate (NAS) solids were noted in blends of waste feed and concentrated recycle downstream of the evaporator for Envelope A waste feeds with concentrated recycles and in one blend of Envelope C waste feed with concentrated recycle. The Envelope A blends that contained NAS solids all contained the minimum amounts of aluminum and hydroxide in the waste matrix. NAS formation was also noted in several Envelope A waste feed concentrated recycle blends tested for validation of the OLI model. The results were compared to tests for the Savannah River Site evaporators and the same trends with hydroxide and aluminum concentration affecting NAS formation were noted. These results accomplish Objective 9.

\subsubsection{Impact of Recycles on Filtration}

Filtration tests were conducted with Envelope A waste/recycle blends to determine the impact of adding recycle to the waste feed. The tests indicated that the primary impact of adding the recycle was to increase the initial solids content of the filtration feed. The increased solids loading led to lower initial permeate rates. These results accomplish Objective 7.

\subsection{Quality Requirements}

This work was conducted in accordance with the RPP-WTP Quality Assurance requirements specified for work conducted by SRTC as identified in DOE IWO MOSRLE60.

Researchers followed the WSRC QA program, which has been approved by WTP, and the WSRC QA Management Plan (WSRC-RP-92-225). The program applied the appropriate QA requirements for this task, as indicated by the QA Plan Checklist in section IX of the Task Technical and Quality Assurance Plan ${ }^{1}$.

Analytical sample labeling and tracking complied with established procedures (WSRC Manual L1, Procedure 7.15). The SRTC Analytical Development Section (ADS) conducted all analyses using the routine level QA program.

The Task Technical \& QA Plan provided the quality requirements for this work. NQA-1 1989, part 1, Basic and Supplementary Requirements and NQA-2a 1990, Part 2.7 were applied as appropriate. 


\subsection{Issues}

Several issues found during testing will need to be addressed by future WTP R\&T programs. None of these issues will impact the startup but these issues could impact the long term operation of the WTP.

\subsubsection{Gel Formation in the Blended UF Recycle Stream}

The formation of aluminum hydroxide gels was noted in the UF recycle when the acid cleaning solution was added per the flowsheet provided by WTP. The gel was caused by the shift in $\mathrm{pH}$ to a region where gel formation is favored for aluminate species and was mitigated by the addition of sodium hydroxide prior to the acid cleaning solution addition to avoid lowering the $\mathrm{pH}$. The formation of gels in the WTP could impact processing and should be mitigated. Given the possible variations in compositions of the UF recycle streams and amounts of acid cleaning solution, accurate measurement or prediction of the $\mathrm{pH}$ of the blended UF recycle streams will be necessary to adjust the $\mathrm{pH}$ as required to mitigate the gel formation or excess $\mathrm{NaOH}$ added to ensure that the required $\mathrm{pH}$ of the blended UF recycle is maintained.

\subsection{2 pH Measurement and Prediction}

Measurement of the $\mathrm{pH}$ of the blended stream could not be conducted with a standard $\mathrm{pH}$ probe as the amount of dissolved salts caused considerable errors. An ISFET $\mathrm{pH}$ probe was utilized in the lab to accurately measure the $\mathrm{pH}$ but the probes were difficult to keep clean and may not be feasible in the WTP.

The prediction of $\mathrm{pH}$ is complicated by the precipitation of dissolved species as the acid cleaning solution is neutralized. During the investigation of the gel formation, OLI modeling was attempted to predict the $\mathrm{pH}$ of the UF recycle and determine the amount of sodium hydroxide required to adjust the $\mathrm{pH}$ to mitigate the gel formation. The $\mathrm{pH}$ prediction in OLI was significantly higher than the experimental results and validation of the UF recycle blending model was not possible. OLI has stated that the $\mathrm{pH}$ prediction has not been previously validated and the accuracy of the prediction was uncertain. The inadequacy of the OLI prediction of $\mathrm{pH}$ affects the modeling of the waste feed evaporation process as the OLI model may not accurately predict the amount of sodium hydroxide required.

\subsubsection{Solid Formation in Recycle}

While NAS solids were not noted in the evaporator feed or concentrate samples, other solids did form and scaling of the evaporator walls and heat exchangers could still be an issue. Since recycles will be used in the WTP pilot evaporator testing program, scaling will be investigated as a part of that program. If significant scaling occurs, then bench scale scaling and evaporator cleaning studies should be pursued. 


\subsubsection{Solids Species in Recycle}

Lithium aluminum carbonate hydroxide hydrate, $\left(\mathrm{Al}_{2} \mathrm{Li}(\mathrm{OH})_{6}\right)_{2} \mathrm{CO}_{3} \cdot \mathrm{xH}_{2} \mathrm{O}$ and sodium strontium phosphate hydrate $\left(\mathrm{NaSr}\left(\mathrm{PO}_{4}\right)_{2} \cdot 5 \mathrm{H}_{2} \mathrm{O}\right)$ were found to precipitate in the UF recycle. These compounds are not found in the OLI Public database. If the formation of these solids causes undesirable effects such as fouling or foaming in the evaporator system, then modeling and further experimentation to determine the solubility of these compounds should be conducted.

\subsubsection{Evaporation of AZ-102 Sludge}

Severe bumping was noted as the AZ-102 sludge was evaporated. Although the bumping may be mitigated by increasing the vessel diameter, the amount of solids buildup on the vessel walls due to splatter in the evaporator could cause operational difficulties even if the amount of bumping is reduced. Pilot scale tests should be conducted to determine if significant operational difficulties persist at larger scales if AZ-102 or other feed containing large amounts of undissolved solids is to be evaporated in the WTP.

\subsubsection{Impact of Recycle on Filtration}

Tests conducted on Envelope A waste feed / recycle blends indicated that the addition of recycle to the waste stream will lower the permeate flux rate. The primary cause of the rate reduction was determined to be the increased amount of insoluble solids in the waste feed / recycle blends versus the waste feed only. The scope of the filtration tests conducted during this task was limited and indicates that further investigation of the impact of recycle on the filtration process should be conducted. Integrated pilot scale tests will be conducted and the impact of recycle on the filtration process will be examined during those tests.

Formation of NAS was noted in selected blends of waste feed and concentrated recycle downstream of the waste feed evaporation. The impact of NAS on the ultrafiltration process is not completely understood and should be investigated.

\subsection{CD/ROM Enclosures}

A CD/ROM titled S90: Waste Feed Evaporation Rheology Data containing the rheograms and raw rheological data from this testing is attached. The data files are listed by sample number. A cross-reference is supplied that provides a description of each sample by sample number.

The recommended minimum computer system is as follows:

- Pentium II running at $233 \mathrm{MHz}$

- $32 \mathrm{MB}$ ram

- Windows 95 or later.

\subsection{Discussion}

The overall objective of this study is to characterize operation of the waste evaporation evaporator. The evaporator will primarily concentrate recycle streams prior to blending the 
WSRC-TR-2003-00212, Rev. 0

SRT-RPP-2003-00094, Rev. 0

recycle with the waste feed to target a blended supernate specific gravity of 1.22 , as shown in Figure 1 for Envelope A. Envelope $\mathrm{C}$ waste is higher in Na molarity than Envelope A and will use the flowsheet as shown with the exception of the leach and $2^{\text {nd }}$ wash solutions in the UF recycle. The waste feed for Envelope $\mathrm{B}$ is below 5 molar $\mathrm{Na}$ and was blended with recycle prior to evaporation.

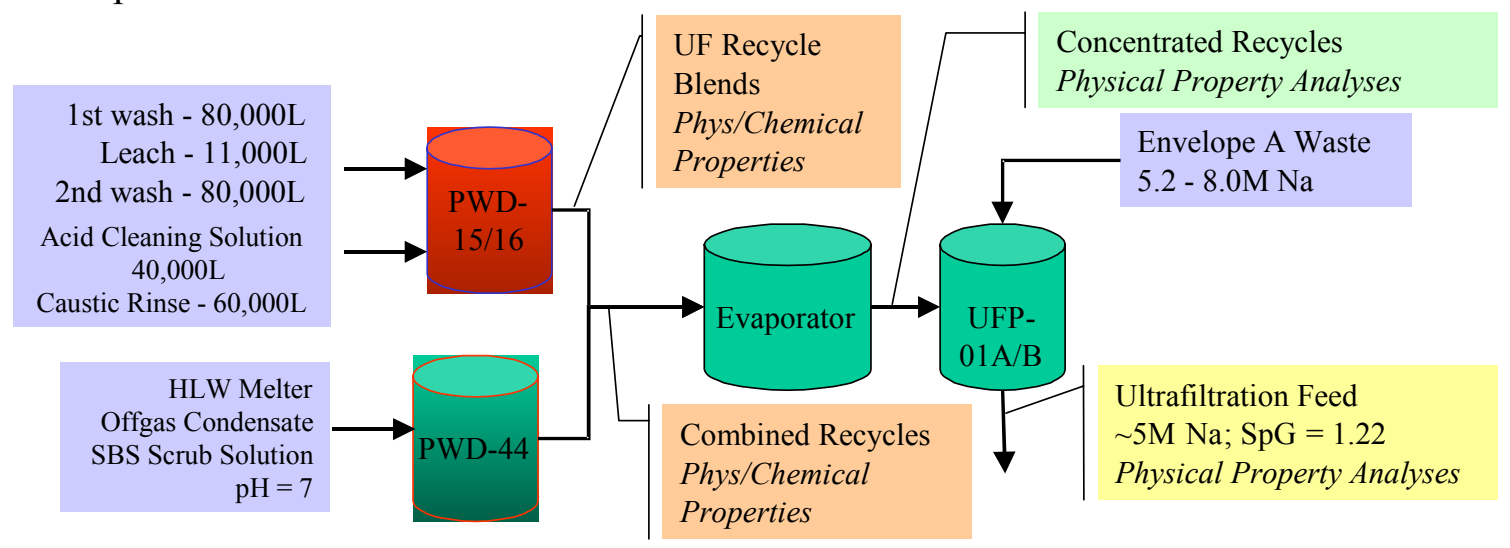

Figure 1. Waste Feed Evaporation Flowsheet

The operating region for the waste feed evaporator was determined by calculation of "operating curves" and "recycle concentration curves". The "operating curve" was determined by calculation of the required concentration of recycle required to dilute a waste feed to $5 \mathrm{M}$ sodium versus amount of recycle. Calculating the change in volume percent of the recycle as it is evaporated generated the "recycle concentration curves". When the "operating curve" and the "recycle concentration curve" are plotted together, the intersection represents the operating point. If the two curves do not intersect, then either the recycle cannot be concentrated to meet the required molarity target or water must be added to further dilute the waste feed. For example, if the recycle stream is $1 / 2$ the volume of the waste feed, then it represents $33 \%$ of the combined stream prior to evaporation. If the recycle is $0.3 \mathrm{M}$ and the waste feed is $7 \mathrm{M}$, then the intersection of the $33 \%, 0.3 \mathrm{M}$ recycle concentration curve with the $7 \mathrm{M}$ operating curve represents the operating point, as shown by point A in Figure 2. The recycle would be evaporated to approximately $0.4 \mathrm{M} \mathrm{Na}$ to create a blended stream with a target specific gravity of 1.22 .

Operating and recycle concentration curves were generated for the expected range of waste feed and recycle concentrations and amounts. The operating region for the evaporator is the area between the intersections of the curves and bounds the expected operating region of the evaporator, as shown in Figure 2. 
WSRC-TR-2003-00212, Rev. 0

SRT-RPP-2003-00094, Rev. 0

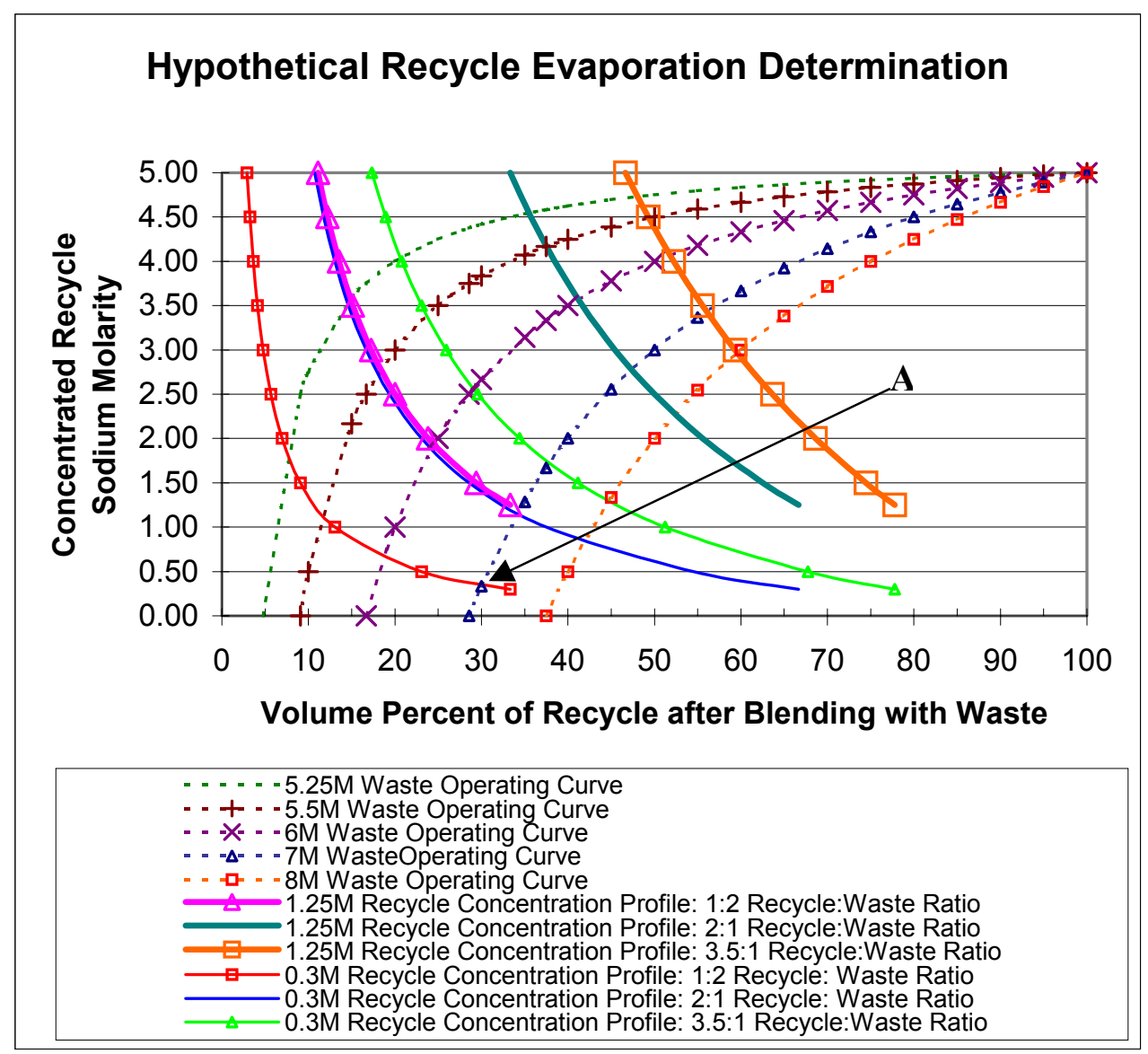

Figure 2. Hypothetical Evaporation Endpoint Determination

Several observations from the chart above should be noted. First, when waste feed is $7 \mathrm{M}$ or greater, very little or no evaporation is required for recycle streams that are up to $1 / 2$ the volume of the waste feed. Second, concentration of dilute streams results in rapid loss of volume such that evaporation to high sodium concentrations is not required. Last, the evaporation endpoint is very dependent on the initial recycle sodium concentration such that switching from recycle with and without UF recycle will significantly change the evaporation endpoint.

The operating region can be determined in the same manner for dilute waste feeds $(<5 \mathrm{M} \mathrm{Na})$ such as AY-102/C-106, as shown in Figure 3 to determine if the waste feed can be adjusted to $5 \mathrm{M}$ sodium by concentration of the recycle to higher molarities. As shown by the charts, excessive volume reductions would be required to shift the molarity of dilute waste feeds upward. For example, to adjust waste feed that is $3 \mathrm{M}$ to $5 \mathrm{M}$ sodium would require that the recycle be adjusted past $10 \mathrm{M}$ sodium content as shown by the intersection of the $5 \mathrm{M}$ operating line with the recycle concentration lines in the left chart of Figure 3. 
WSRC-TR-2003-00212, Rev. 0

SRT-RPP-2003-00094, Rev. 0

\section{Hypothetical Recycle Evaporation Determination \\ With 3.0M Feed}
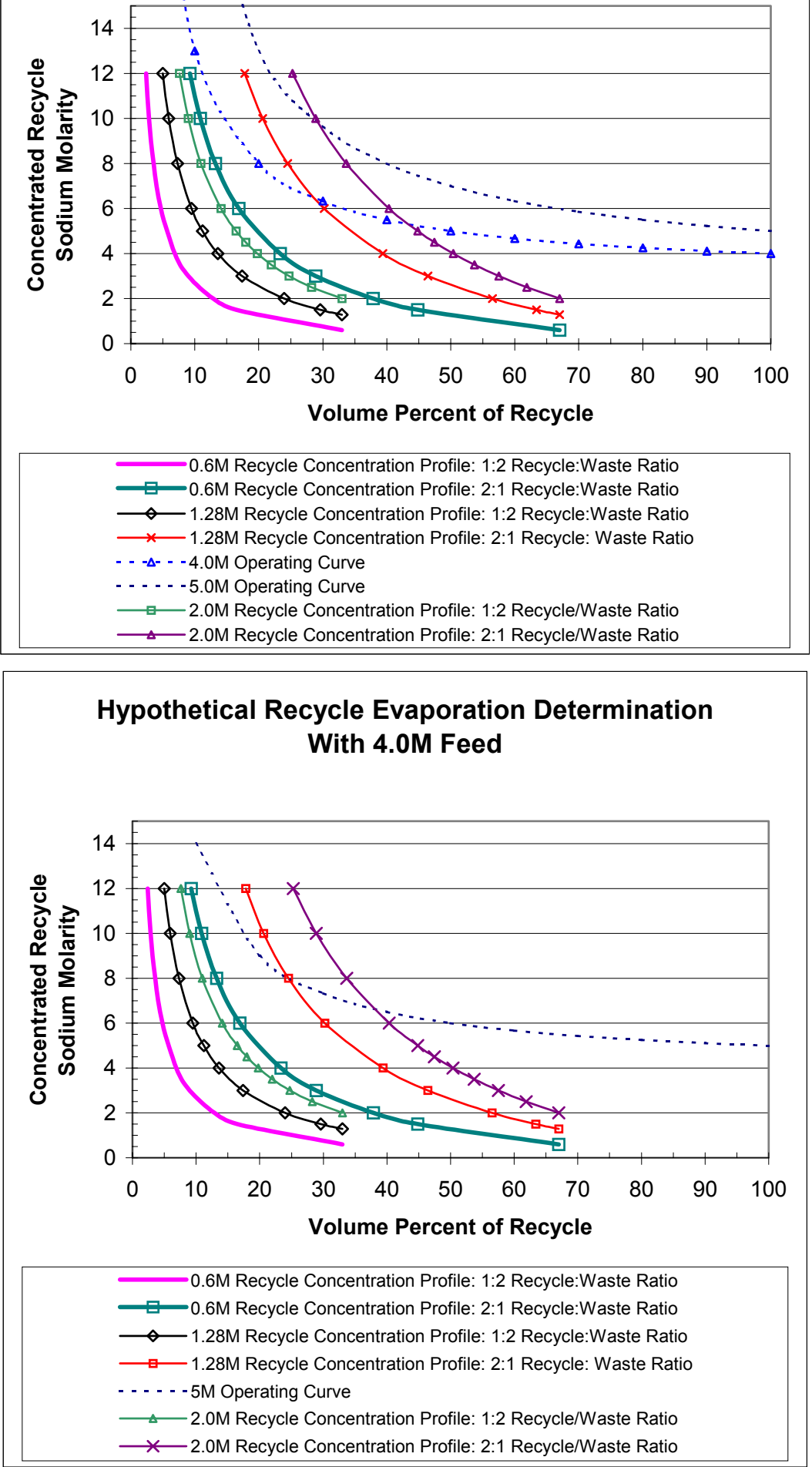

Figure 3. Hypothetical Evaporation Endpoint Determinations with 3M and 4M Feeds 


\subsection{Waste and Recycle Simulants}

The test program required simulants for each of the recycles and waste feeds. Simulants developed or generated during previous testing on the WTP process were utilized where available. Simulants were developed for Envelope A waste feeds, Envelopes A and B UF recycles, and Envelope $\mathrm{C}$ acid cleaning solution.

\subsubsection{Envelope A Waste Simulants}

The test matrix shown in Table 1 for Envelope A LAW was developed by Eibling/Edwards based upon a review of TFCOUP 3A using statistical routines available in a commercial software package. ${ }^{2}$ The matrix is designed to bound the composition of Envelope A wastes expected to be processed by the WTP. ${ }^{3}$ The concentrations of $\mathrm{Na}, \mathrm{Cl}$, and $\mathrm{Si}$ for each matrix point were fixed at $5,0.102$, and $0.00636 \mathrm{~mol} / \mathrm{L}$, respectively. ${ }^{4}$ The following constraints were utilized to ensure that the statistical matrix points represented viable points for testing:

* The solutions must be charge balanced.

* The molar ratio of aluminum to hydroxide must be less than 0.7

* The phosphate and fluoride concentrations must satisfy the following equation:

$$
\mathrm{PO}_{4}(\mathrm{~mol} / \mathrm{L})+0.07 \cdot \mathrm{F}(\mathrm{mol} / \mathrm{L}) \leq 0.05
$$

Table 1. Envelope A Simulant Matrix

\begin{tabular}{|c|c|c|c|c|c|c|c|c|c|c|c|c|}
\hline Test & $\mathrm{Al}$ & $\mathrm{Cl}$ & $\mathrm{CO}_{3}^{-2}$ & $\mathrm{~F}$ & $\mathrm{NO}_{2}$ & $\mathrm{NO}_{3}$ & $\mathrm{Na}$ & $\mathrm{OH}^{-}$ & $\mathrm{PO}_{4}$ & $\mathrm{SO}_{4}$ & $3_{3}^{-2}$ & Oxala \\
\hline ID & $\mathrm{mol} / \mathrm{L}$ & $\mathrm{mol} / \mathrm{L}$ & $\mathrm{mol} / \mathrm{L}$ & $\mathrm{mol} / \mathrm{L}$ & $\mathrm{mol} / \mathrm{L}$ & $\mathrm{mol} / \mathrm{L}$ & $\mathrm{mol} / \mathrm{L}$ & $\mathrm{hol} / \mathrm{L}$ & $\mathrm{mol} / \mathrm{L}$ & $\mathrm{mol} / \mathrm{L}$ & $\mathrm{mol} / \mathrm{L}$ & \\
\hline SM01 & 0.71791 & 0.10200 & 0.68599 & 0.00928 & 0.73098 & 0.99098 & 5.00000 & 1.02559 & 0.00632 & 0.00586 & 0.00636 & 393 \\
\hline M02 & 0.20699 & 0.10200 & \begin{tabular}{|l|}
0.68599 \\
\end{tabular} & 23601 & \begin{tabular}{|l|}
0.73098 \\
\end{tabular} & 18854 & 5.00000 & & & 0.05440 & 00636 & \\
\hline SM03 & 0.20699 & 0.10200 & 0.42878 & 00928 & 1.59001 & 0.99098 & 5.00000 & & & & 0.00636 & \\
\hline SM04 & 0.20699 & 0.1 & 61 & 23601 & 0.73098 & 0.99098 & 5.0 & & 48 & 0.00586 & 36 & \\
\hline SM0 & 0.20699 & & & 8 & 98 & 88 & & & & & & \\
\hline SM06 & 699 & 0.1 & & 28 & \begin{tabular}{|l|}
0.73098 \\
\end{tabular} & 01 & 5.0 & & & & & \\
\hline SM07 & 1.12000 & 0.10200 & 0.03261 & 00928 & \begin{tabular}{|l|}
0.73098 \\
\end{tabular} & 0.99098 & 5.0 & & 0.0 & & 36 & \\
\hline SM08 & 0.20699 & & 61 & 00928 & 1.59001 & 1.96007 & 5.0 & & & & 636 & \\
\hline SM09 & 0.65443 & 0.10200 & 0.03261 & 0.23601 & 0.73098 & 2.08001 & 5.00000 & 0.98 & 0.00 & 0.05440 & 0.00636 & 393 \\
\hline SM10 & 0.80892 & 0.10200 & 0.03261 & 0.23601 & 1.59001 & 0.99098 & 5.00000 & 1.15560 & 0.00632 & 0.00586 & 0.00636 & 0.00393 \\
\hline SM11 & 737 & & 0.22 & 0.11357 & 1.00689 & 1.35628 & 5.000 & 1.2 & & 0.02946 & 0.00636 & 0.01189 \\
\hline M12 & 0.54737 & 0.10200 & 0.22536 & 0.11357 & 1.00689 & 1.35628 & 5.00000 & 1.24893 & 0.02627 & 0.02946 & 0.00636 & 0.01189 \\
\hline
\end{tabular}

${ }^{2}$ T. B. Edwards, A Statistical Design to support RPP LAW Feed Simulant Testing (U), SRTSCS-2002-00027, Westinghouse Savannah River Company, Aiken SC, May $20^{\text {th }} 2002$.

${ }^{3}$ The tanks (AP-101, AN104, AN105, SY-101, AN103, AW-101, \& AW-104) used to complete this matrix represent the Envelope A waste that will be processed by the WTP to meet the triparty milestone M-62-00A, "Complete Pretreatment, Processing and Vitrification of Hanford Phase 1 HLW and Low Activity Waste (LAW)," due February 28, 2018.

${ }^{4}$ The chloride was fixed to match the average Envelope A concentration and the Si was set to match the maximum Envelope A concentration. 
WSRC-TR-2003-00212, Rev. 0

SRT-RPP-2003-00094, Rev. 0

The twelve Envelope A matrix simulants were made up at 5M sodium concentration, filtered, and sampled for physical properties during the Treated Feed Evaporator testing. ${ }^{5}$ For the waste feed evaporator, the matrix points were adjusted to $7 \mathrm{M}$ sodium to better represent the nominal concentration of the Envelope A tanks listed in the TFCOUP report. The midpoint of the matrix (SM-11) was also made up at 5.2M sodium to determine the impact of lowering the sodium molarity on the waste feed blending with recycle.

\subsubsection{Envelope B Waste Simulants}

Envelope B consists of two tanks, AZ-101 and AZ-102. The testing for the waste feed evaporator focused on AZ-102 since the waste in this tank is low in sodium and requires evaporation to adjust the sodium content to $5 \mathrm{M}$. This tank is the only tank other than C-106/AY102 that requires evaporation in the waste feed evaporator.

Washed solids from sludge simulants utilized in previous testing was adjusted by adding concentrated supernate to target $2.7 \mathrm{M}$ sodium in the supernate. The composition of the final sludge simulant for AZ-102 used during the waste feed evaporator testing is shown in Appendix A.

\subsubsection{Envelope C Waste Simulants}

Simulants of the two Envelope C tanks (AN-102 and AN-107) were utilized during the testing. Simulants previously developed for pilot plant studies were adjusted for sodium content and utilized for this testing. The compositions of these simulants are shown in Appendix A.

\subsubsection{HLW Melter Offgas Condensate}

The condensate and scrub solutions generated during vitrification of the HLW is recycled back to the waste feed evaporator. VSL pilot plant studies of the vitrification process had generated large amounts of this condensate. A sample of this condensate was obtained from VSL and utilized during this study after neutralization to a $\mathrm{pH}$ of 7.0 with $19 \mathrm{M} \mathrm{NaOH}$. Sample analysis of this condensate is shown in Table 2. XRD analysis indicated that the solids present in the sample were primarily quartz. This sample was utilized for all envelopes.

${ }^{5}$ J. E. Josephs, Treated Feed Evaporation: Physical Properties and Solubility Determination (U), WSRC-TR-2003-000119, March 2003. 
Table 2. Melter Offgas Condensate Composition after Neutralization

\begin{tabular}{|l|c|}
\hline Element / Anion & Molarity \\
\hline & \\
\hline Aluminum & $2.77 \mathrm{E}-03$ \\
\hline Boron & $4.75 \mathrm{E}-02$ \\
\hline Cadmium & $6.60 \mathrm{E}-05$ \\
\hline Calcium & $2.47 \mathrm{E}-04$ \\
\hline Chloride & $1.49 \mathrm{E}-02$ \\
\hline Fluoride & $4.53 \mathrm{E}-03$ \\
\hline Iron & $1.60 \mathrm{E}-03$ \\
\hline Lithium & $2.99 \mathrm{E}-04$ \\
\hline Manganese & $2.20 \mathrm{E}-04$ \\
\hline Nickel & $8.70 \mathrm{E}-05$ \\
\hline Nitrate & $5.00 \mathrm{E}-03$ \\
\hline Oxalate & $3.10 \mathrm{E}-04$ \\
\hline Phosphate & $3.27 \mathrm{E}-03$ \\
\hline Potassium & $2.00 \mathrm{E}-04$ \\
\hline Silicon & $2.87 \mathrm{E}-03$ \\
\hline Sodium & $1.00 \mathrm{E}-02$ \\
\hline Strontium & $4.12 \mathrm{E}-04$ \\
\hline Sulfate & $3.96 \mathrm{E}-03$ \\
\hline Zinc & $5.18 \mathrm{E}-03$ \\
\hline Zirconium & $8.80 \mathrm{E}-05$ \\
\hline
\end{tabular}

\subsubsection{Ultrafiltration Recycles}

The ultrafiltration recycle consists of five different solutions: $1^{\text {st }}$ wash, Leach, $2^{\text {nd }}$ wash, Acid cleaning, and caustic rinse solutions. The recycles are blended together prior to transfer to the evaporator feed tank and subsequent blending with the melter offgas condensate. Simulants were generated for each individual stream in the recycle and blended together based upon the volume calculations conducted by WTP ${ }^{6}$. Formation of gels in the blended streams led to the addition of a caustic adjustment step to $\mathrm{pH}=13$ in the recycle process, as discussed below and Appendix D. The basis and composition for each stream and the volume ratios of the blended recycle are shown below for each of the different waste envelopes.

\subsubsection{Envelope A UF Recycles}

The first wash for Envelope A was based upon dilution of the Envelope A matrix midpoint (SM11 in Table 1) according to the dilution calculation provided by WTP. ${ }^{5}$ The amount of oxalate was set to the same level as the waste feed on the assumption that the oxalate would be soluble to the same extent in the wash as it was in the waste feed. The leach solution and second wash

${ }^{6}$ M. E. Stone, Waste Feed Evaporator Preliminary Test Matrix Revision 2, SRT-GDP-2002-00095, Westinghouse Savannah River Company, Aiken, SC, October 8, 2002. 
WSRC-TR-2003-00212, Rev. 0

SRT-RPP-2003-00094, Rev. 0

were based on the assumption that the solids in the Envelope A waste were Envelope D solids. The compositions of leach and $2^{\text {nd }}$ wash solutions from a PNNL study ${ }^{7}$ on actual waste were used to generate the leach and $2^{\text {nd }}$ wash simulants.

The acid cleaning solution was based on a WTP estimate ${ }^{5}$ of the solids holdup in the filter system and the amount of acid cleaning solution to be utilized in cleaning the filter. The concentration of solids in the acid cleaning solution was determined and that amount of Envelope D simulated solids was dissolved in $2 \mathrm{M}$ nitric acid to produce the simulant. The caustic wash was simulated with $0.1 \mathrm{M}$ sodium hydroxide since all the solids held up in the filter were added to the acid cleaning solution. Compositions of the streams and blended recycle for Envelope A are shown in Appendix A.

\subsubsection{Envelope B UF Recycles}

The recycle compositions for Envelope B were identical to the Envelope A streams since Envelope D solids were utilized to generate the expected compositions for the Envelope A recycle, with the exception of the first wash. The $1^{\text {st }}$ wash was determined in the same manner as the $1^{\text {st }}$ wash for Envelope A with the substitution of the AZ-102 supernate composition in place of the Envelope A matrix midpoint. Compositions of the streams and blended recycle for Envelope B are shown in Appendix A.

\subsubsection{Envelope C UF Recycles}

The recycle for Envelope C differs from Envelopes A and B in that a leach step is not conducted. The recycle consists only of a $1^{\text {st }}$ wash, acid cleaning solution, and caustic rinse. The $1^{\text {st }}$ wash solution for Envelope $\mathrm{C}$ was obtained from pilot plant studies at the Engineering Development Laboratory of SRTC conducted with AN-102 simulants. The acid cleaning conducted in the pilot plant testing was not prototypical and was not utilized. A simulant for the acid cleaning solution was developed in the same manner as the acid cleaning solutions for Envelopes $\mathrm{A}$ and B. Compositions of the streams and blended recycle for Envelope $\mathrm{C}$ are shown in Appendix A.

\subsubsection{Volume Ratios for Blending}

The volume ratios of the individual recycle streams were provided by $\mathrm{WTP}^{5}$ and are shown below. The leach option and no-leach option during UF processing were both evaluated for Envelopes A, the leach option was evaluated for Envelope B, and the no-leach option was tested for Envelope C. In addition, the leach option was tested without acid cleaning solution during Envelope A testing.

${ }^{7}$ K. P. Brooks, et al. Characterization, Washing, Leaching, and Filtration of AZ-102 Sludge, BNFL-RPT-038, Rev 0. August 2000. 


\section{Leach Option (UF1) ${ }^{8}$}

- $1^{\text {st }}$ Wash solution:

80,000 liters

- Leach solution:

11,000 liters

- $2^{\text {nd }}$ Wash solution:

80,000 liters

- Acid Cleaning solution:

60,000 liters

- Caustic Rinse from cleaning:

40,000 liters

$>$ Leach Option w/o Acid Cleaning (UF2)

- $1^{\text {st }}$ Wash solution:

80,000 liters

- Leach solution:

11,000 liters

- $2^{\text {nd }}$ Wash solution:

80,000 liters

$>$ No-Leach Option (UF3)

- Wash Solution:

80,000 liters

- Acid Cleaning solution:

40,000 liters

- Caustic Rinse from cleaning:

60,000 liters

\subsubsection{Gel Formation during UF Recycle Blending}

During initial makeup of the blended UF recycle, formation of gels was noted. The gels were formed nearly instantly when the acid cleaning solution was added to the other solutions in the UF recycle. A study was initiated to determine the amount of acid cleaning solution that could be added to the rest of the recycles without formation of gels. As shown in Figure 4, the formation of gels was minimized by a reduction of the acid cleaning solution. The amount of acid cleaning solution added to the recycle increases from sample UF1-1 to UF1-8. Figure 5 shows the appearance of the UF recycles prior to addition of the acid cleaning solution.

${ }^{8}$ The leach option (UF1) acid cleaning solution was tested at three acid cleaning volumes instead of two due to a batching error. The results were reviewed to verify that the actual batching amounts were used in calculations of the results and the calculations matched the as batched compositions. Three volumes of acid cleaning solution reflects the current flowsheet, therefore the results remain valid. 


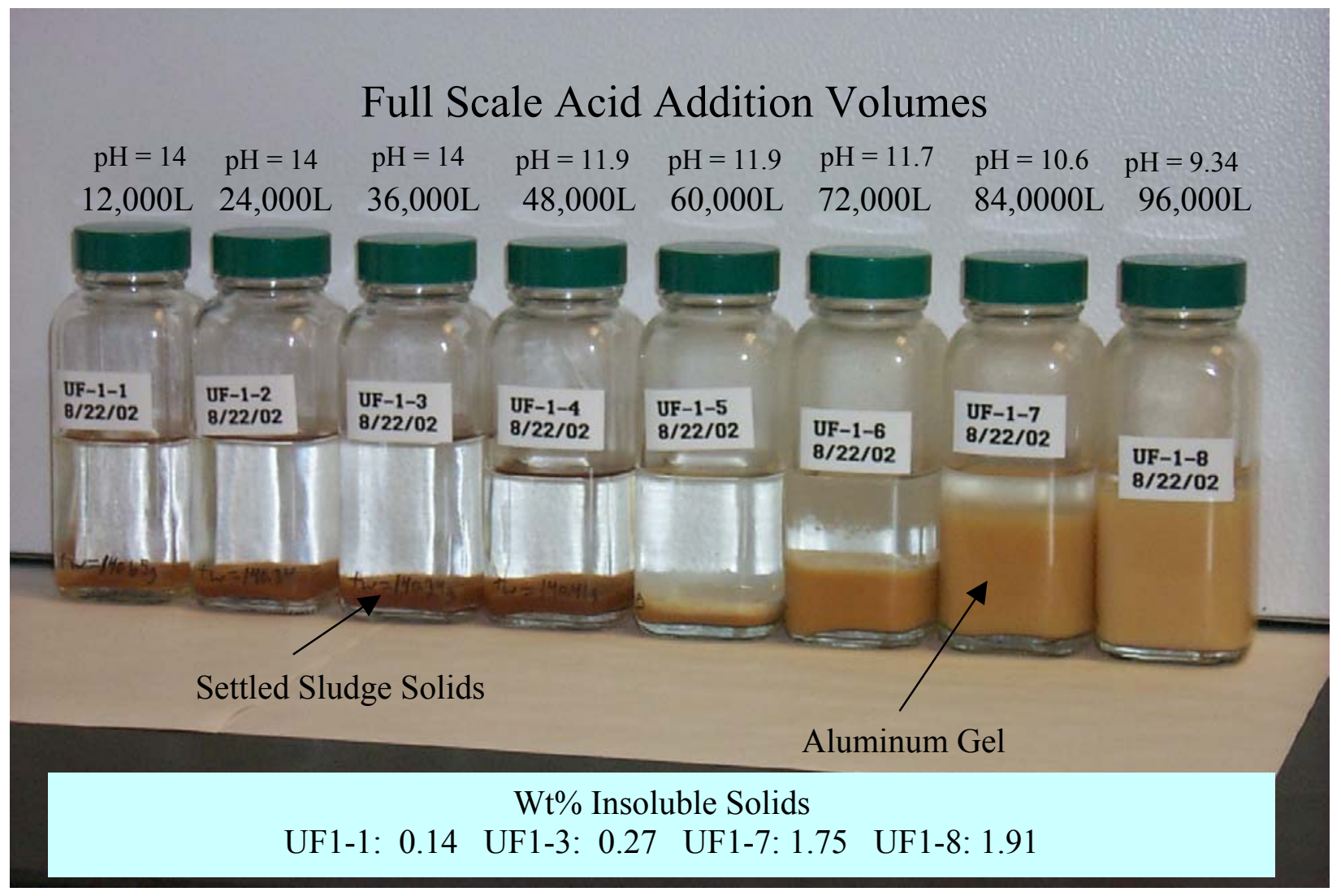

Figure 4. Formation of Gels in Envelope A UF Recycles

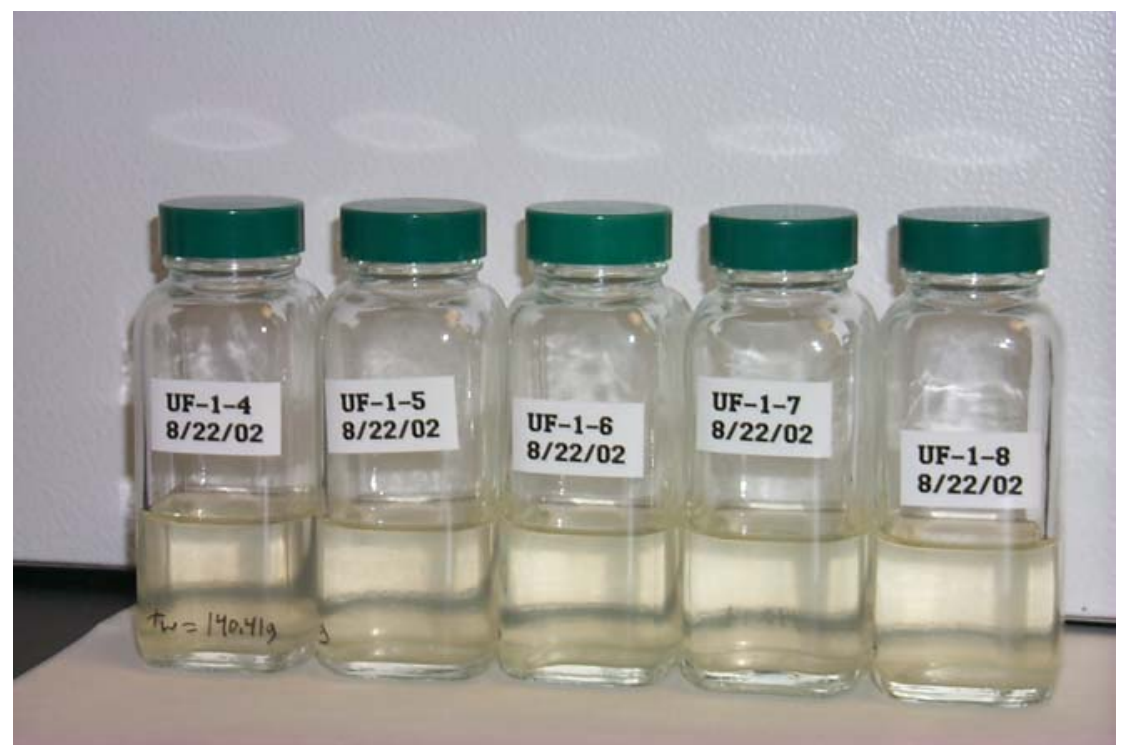

Figure 5. UF Recycles without Acid Cleaning Solution Addition

The gels were identified as aluminum based by XRD analysis and were the result of the acid cleaning solution addition lowering the $\mathrm{pH}$ of the blended solutions into regions where aluminum is not stable. The amounts of acid cleaning solution generated in the UF recycle could be greater than the amount where gel formation began, therefore gel formation was mitigated by the 
WSRC-TR-2003-00212, Rev. 0

SRT-RPP-2003-00094, Rev. 0

addition of 19M sodium hydroxide to the UF recycle blends to maintain a $\mathrm{pH}$ of 13 in the blended slurries. Table 3 shows the amounts of caustic added to each type of recycle during lab testing and the amounts after scale up.

Table 3. Caustic Additions to Mitigate Gel Formation in UF Recycle

\begin{tabular}{|l|c|c|c|c|}
\hline Recycle Type & $\begin{array}{c}\text { Amount of Wash, } \\
\text { Leach and Caustic } \\
\text { Rinse Streams }\end{array}$ & $\begin{array}{c}\text { Acid } \\
\text { Cleaning } \\
\text { Amount }\end{array}$ & $\begin{array}{c}19 \mathrm{M} \mathrm{NaOH} \\
\text { Required } \\
\text { Labscale }\end{array}$ & $\begin{array}{c}19 \mathrm{M} \mathrm{NaOH} \\
\text { Required } \\
\text { Fullscale }\end{array}$ \\
\hline Units & $\mathrm{ml}$ & $\mathrm{ml}$ & grams & $\mathrm{kg}$ \\
\hline Envelope A Leach Option & 77.9 & 22.1 & 0.28 & 760 \\
\hline Envelope A No Leach Option & 77.8 & 22.2 & 1.3 & 2340 \\
\hline Envelope B Leach Option & 77.9 & 22.1 & 6.55 & 17,750 \\
\hline Envelope B No Leach Option & 77.8 & 22.2 & 11.0 & 19,800 \\
\hline Envelope C No Leach Option & 77.8 & 22.2 & 1.34 & 2430 \\
\hline
\end{tabular}

OLI modeling was conducted to determine the amounts of caustic required to maintain the $\mathrm{pH}$ of each UF recycle blend at 13 , but the model failed to accurately predict $\mathrm{pH}$, as discussed in Appendix D.

It should be noted that the amount of caustic required to adjust the blended UF recycle to the required $\mathrm{pH}$ and the $\mathrm{pH}$ required to prevent gel formation will be impacted by changes in composition of the individual recycle streams. For example, UF recycle from process runs that are low in aluminum may not form problematic solids as easily as recycle from runs high in aluminum. The amount of solids dissolved by the caustic leach or acid cleaning solutions will effect how these solutions impact the $\mathrm{pH}$ of the final blended recycle. The caustic additions reflected in this document reflect what was used in the evaporation testing on the compositions of UF recycle tested by this program.

\subsubsection{Other Recycles}

Recycle streams that are processed by the waste feed evaporator that were not included as part of this study include: Cerium decontamination solution, cesium ion exchange column rinse, and the process vessel vent caustic scrub solution. These streams were considered to be either too dilute or too low in volume to impact the tests at the direction of the WTP customer.

\subsection{Evaporation of HLW Melter Offgas Condensate}

The melter offgas condensate (MOGC) from the High Level Waste (HLW) melter will be recycled back to the waste feed evaporator. The MOGC contains the condensable portion of the melter offgas along with the scrub solutions from the High Efficiency Mist Eliminator (HEME), Wet ElectroStatic Plate (WESP) process, and the Submerged Bed Scrubber (SBS) process. The process stream is extremely dilute and can be characterized as water contaminated with a small amount of entrained solids from the melter feed. 
The amount of concentration of the MOGC was calculated graphically assuming various waste feed concentrations and recycle to waste ratios and assuming that $5 \mathrm{M}$ sodium corresponds to a specific gravity of 1.22 . The operating region for the evaporator for MOGC operation is shown in Figure 6. This graph represents a small portion of the lower left corner of the graph shown in Figure 2. As determined from the graph, the maximum concentration required if the recycle contains only MOGC is approximately $0.2 \mathrm{M}$ sodium.

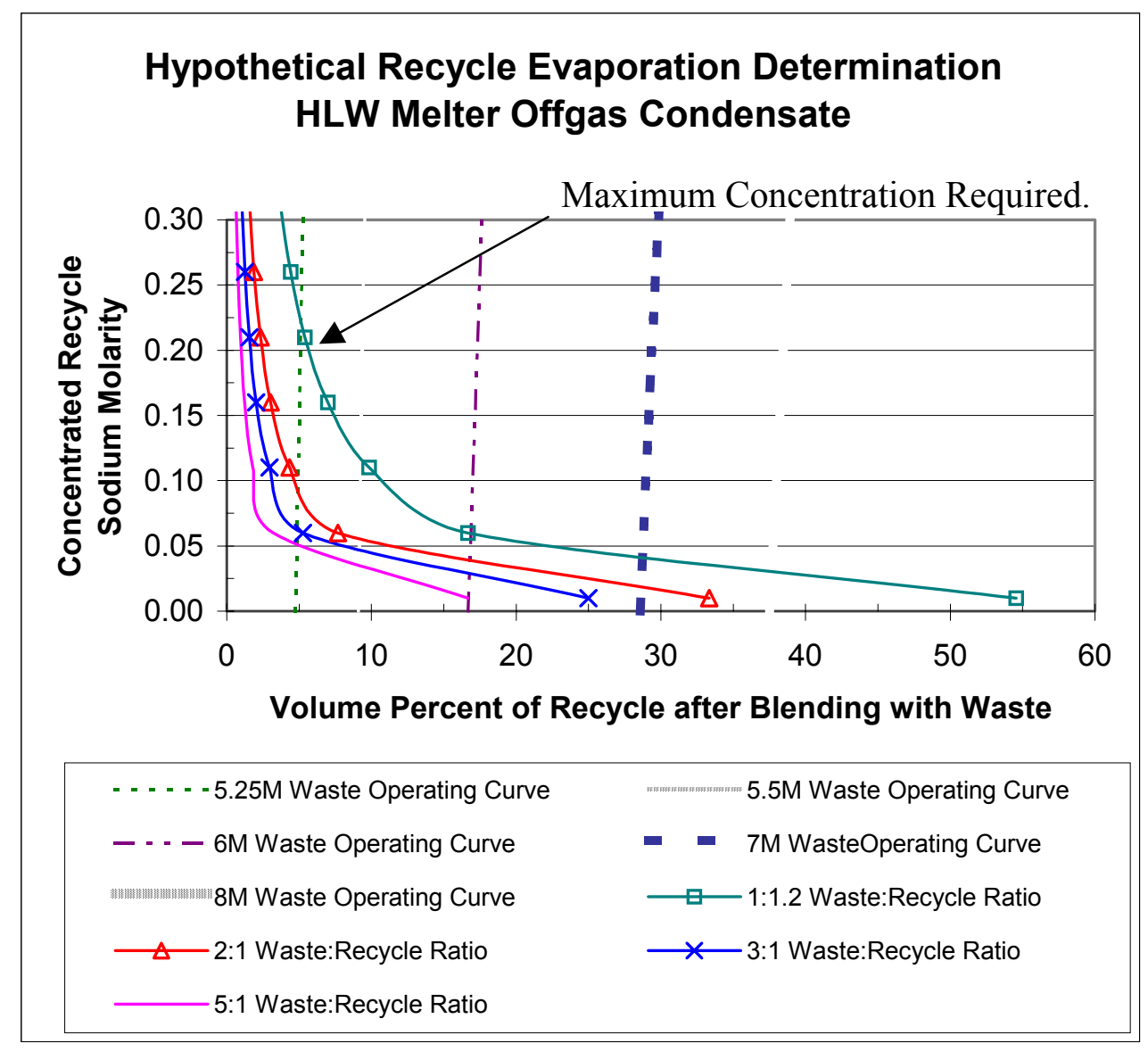

Figure 6. Evaporation Endpoint Determination for MOGC

The $\mathrm{pH}$ of the MOGC as received was 3.60. 19M sodium hydroxide was added to adjust the $\mathrm{pH}$ of the scrub solution to 7 prior to evaporation, increasing the sodium content to approximately $0.01 \mathrm{M}$. The SBS scrub solution was evaporated from a concentration of $0.01 \mathrm{M}$ Na to a concentration of $0.2 \mathrm{M} \mathrm{Na}$. Approximately four liters of feed solution was fed to the evaporator and concentrated to a final volume of $250 \mathrm{ml}$ with a $30 \mathrm{ml}$ intermediate sample at $0.08 \mathrm{M} \mathrm{Na}$. The evaporation was conducted at 27 inches of mercury vacuum (1 psia) in a semi-batch process using the apparatus shown in Appendix B.

Very little foaming was noted during evaporation of the recycle, as shown in Figure 7. The flux rate obtained was $10 \mathrm{ml} / \mathrm{min}$, approximately $20 \%$ of the design basis flux. Particle size was measured on the initial, $0.08 \mathrm{M}$ and $0.2 \mathrm{M}$ samples, no significantly change in size was noted, as shown in Table 4. The amount of insoluble solids after evaporation indicates that a small 
WSRC-TR-2003-00212, Rev. 0

SRT-RPP-2003-00094, Rev. 0

amount of solids precipitation may have occurred, but the increase in solids is within the error of the weight percent solids measurement method.Specific gravity was determined and vapor pressure data was utilized to determine expected evaporator temperatures, as shown in Table 4. Heat capacity, thermal conductivity, and rheology were not determined for these samples due to the low concentration of salts.

Table 4. Evaporation Parameters for MOGC

\begin{tabular}{|c|c|c|c|c|c|c|c|c|}
\hline Run \# & $\begin{array}{c}\text { UF } \\
\text { Recycle } \\
\text { Type }\end{array}$ & $\begin{array}{c}\text { MOGC } \\
\text { Amount }\end{array}$ & $\begin{array}{c}\text { Initial Na } \\
\text { Molarity }\end{array}$ & $\begin{array}{c}\text { Initial } \\
\text { SpG } \\
\text { of } \\
\text { Slurry }\end{array}$ & $\begin{array}{c}\text { Initial } \\
\text { Temp } \\
\text { Vp=0.09 } \\
\text { bar }\end{array}$ & $\begin{array}{c}\text { Final Na } \\
\text { Molarity }\end{array}$ & $\begin{array}{c}\text { Final } \\
\text { SpG } \\
\text { of } \\
\text { Slurry }\end{array}$ & $\begin{array}{c}\text { Final } \\
\text { Temp }=0.09 \\
\text { bar }\end{array}$ \\
\hline MOGC & None & 100 & 0.01 & 1.002 & 44.7 & 0.2 & 1.039 & 45.4 \\
\hline
\end{tabular}

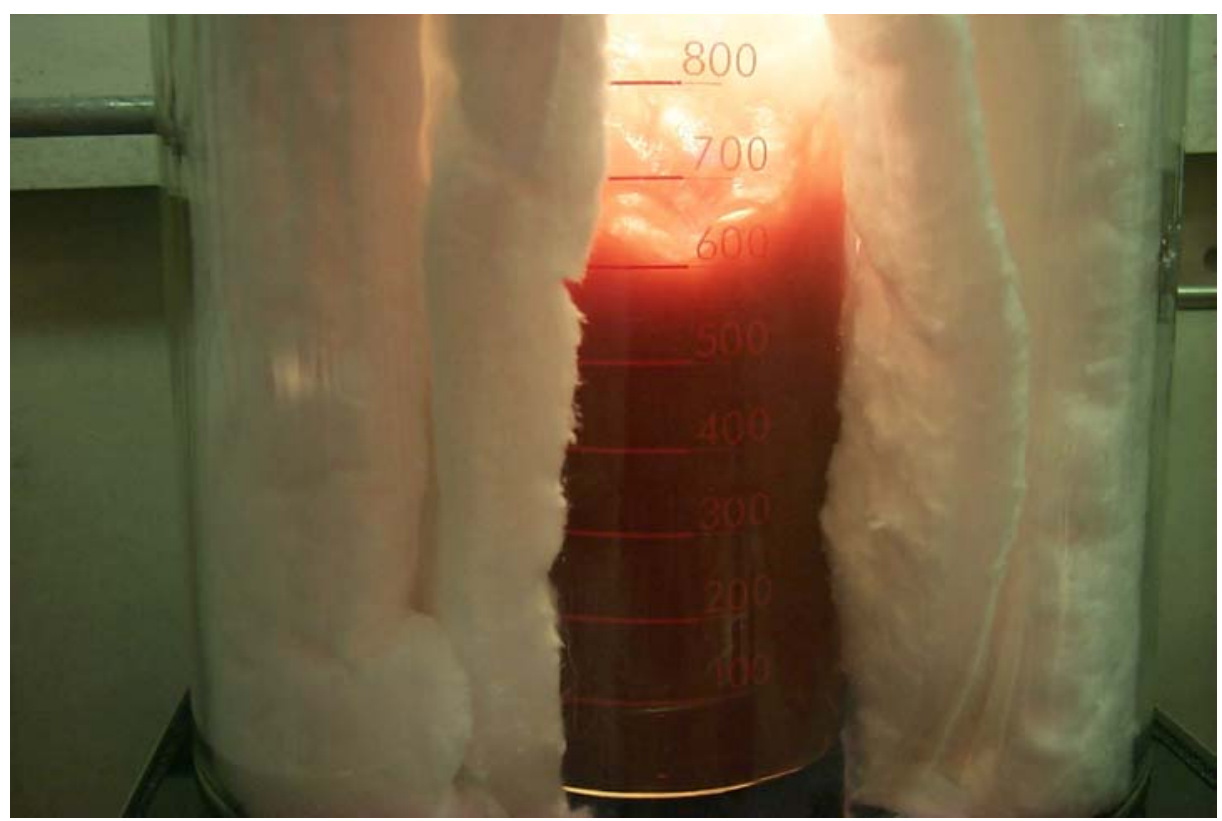

Figure 7. Evaporation of Melter Offgas Condensate

\subsection{Evaporation of Recycles}

During Envelope A testing, the leach option and no-leach option recycle streams from the ultrafiltration process were evaporated with $0 \%, 25 \%, 50 \%$, and 75\% MOGC (by volume) as well as the leach option without acid cleaning solution at 25\% MOGC. For Envelopes B and C, only the $0 \%$ and $50 \%$ MOGC cases were tested, as shown in Table 5 . The evaporation was conducted at 27 inches of mercury vacuum (1 psia) in a batch process using the apparatus shown 
in Appendix B. Samples were taken of the initial mixture, at approximately $1.5 \mathrm{M} \mathrm{Na}, 3 \mathrm{M} \mathrm{Na}$ and of the final mixture.

Table 5. Run Parameters for Recycle Evaporations

\begin{tabular}{|c|c|c|c|c|c|c|c|c|}
\hline Run \# & $\begin{array}{c}\text { UF } \\
\text { Recycle } \\
\text { Type }\end{array}$ & $\begin{array}{l}\text { MOGC } \\
\text { Amount }\end{array}$ & $\begin{array}{l}\text { Initial Na } \\
\text { Molarity }\end{array}$ & $\begin{array}{c}\text { Initial } \\
\text { SpG } \\
\text { of } \\
\text { Slurry } \\
\end{array}$ & $\begin{array}{c}\text { Initial } \\
\text { Temp } \\
\text { Vp=0.09 } \\
\text { Bar } \\
\end{array}$ & $\begin{array}{l}\text { Final Na } \\
\text { Molarity }\end{array}$ & $\begin{array}{c}\text { Final } \\
\text { SpG } \\
\text { of } \\
\text { Slurry } \\
\end{array}$ & $\begin{array}{c}\text { Final } \\
\text { Temp } \\
\text { Vp }=0.09 \\
\text { Bar }\end{array}$ \\
\hline & & Vol \% & Molar & & Celsius & Molar & & Celsius \\
\hline MOGC & None & 100 & 0.01 & 1.005 & 44.7 & 0.2 & 1.042 & 45.4 \\
\hline UF1A-0 & $\begin{array}{l}\text { Leach } \\
\text { Ontion }\end{array}$ & 0 & 1.3 & 1.073 & 45.5 & 5.46 & 1.297 & 47.8 \\
\hline UF1A-25 & $\begin{array}{l}\text { Leach } \\
\text { Option }\end{array}$ & 25 & 1.04 & 1.054 & 45.5 & 5.24 & 1.278 & 47.8 \\
\hline UF1A-50 & $\begin{array}{l}\text { Leach } \\
\text { Option }\end{array}$ & 50 & 0.67 & 1.040 & 43.4 & 5.49 & 1.295 & 47.9 \\
\hline UF1A-75 & $\begin{array}{l}\text { Leach } \\
\text { Option }\end{array}$ & 75 & 0.37 & 1.021 & 45.1 & 5.45 & 1.305 & 47.9 \\
\hline UF3A-0 & $\begin{array}{c}\text { No } \\
\text { Leach }\end{array}$ & 0 & 1.59 & 1.085 & 44.4 & 5.48 & 1.276 & 47.8 \\
\hline UF3A-25 & $\begin{array}{c}\text { No } \\
\text { Leach }\end{array}$ & 25 & 1.18 & 1.064 & 44.9 & 5.58 & 1.270 & 47.7 \\
\hline UF3A-50 & $\begin{array}{c}\text { No } \\
\text { Leach }\end{array}$ & 50 & 0.81 & 1.044 & $\mathrm{~nm}^{\#}$ & 5.67 & 1.299 & 48.0 \\
\hline UF3A-75 & $\begin{array}{c}\text { No } \\
\text { Leach }\end{array}$ & 75 & 0.41 & 1.024 & 45.3 & 5.30 & 1.276 & 47.2 \\
\hline UF2A-25 & $\begin{array}{c}\text { No } \\
\text { Acid } \\
\end{array}$ & 25 & 1.44 & 1.079 & 45.9 & 5.39 & 1.272 & 48.3 \\
\hline UF1B & $\begin{array}{l}\text { Leach } \\
\text { Option }\end{array}$ & 0 & 1.97 & 1.101 & 47.2 & 4.89 & 1.231 & 47.6 \\
\hline UF1B-50 & $\begin{array}{l}\text { Leach } \\
\text { Option }\end{array}$ & 50 & 0.99 & 1.053 & 45.54 & 5.12 & 1.244 & 47.7 \\
\hline UF3C & $\begin{array}{c}\text { No } \\
\text { Leach }\end{array}$ & 0 & 2.16 & 1.106 & 46.0 & 5.83 & 1.269 & 47.7 \\
\hline UF3C-50 & $\begin{array}{c}\text { No } \\
\text { Leach }\end{array}$ & 50 & 1.07 & 1.057 & 45.3 & 5.46 & 1.265 & 47.6 \\
\hline
\end{tabular}

\# $\quad$ Not measured accurately due to air leak in vapor pressure instrument during run.

Slight amounts of foaming were noted during the runs, primarily at the start of the run, as shown in Appendix E, Figure E-1 and E-3. Foaming was noted to decrease as the mixture became more concentrated. The evaporation was performed at a reduced flux rate to minimize splattering and 
holdup so that samples would be as representative as possible. The flux rate was approximately $5 \mathrm{ml} / \mathrm{min}$ during most runs, or $0.09 \mathrm{~g} / \mathrm{ml}^{-\mathrm{cm}^{2}}$ compared to a design basis flux of $0.70 \mathrm{~g} / \mathrm{ml}-\mathrm{cm}^{2}$. "Bumping" was noted during most runs, but this process is typically the result of wall effects and should be mitigated by increases in diameter in larger scale processes. Bumping involves the top layer of the evaporating solution being thrown upward by gas bubbles that expand to fill the entire diameter of the evaporation vessel. The stabilization of the bubbles by the vessel walls is not expected to occur at larger scales.

\subsection{Blending of Envelope A Streams}

All Envelope A waste feeds will bypass the waste feed evaporator since the sodium concentration of the feeds is greater than five molar, therefore the recycle stream will be evaporated as required to dilute the waste feed to target a supernate specific gravity of 1.22. The $7 \mathrm{M}$ waste simulants from the Envelope A matrix were blended with evaporated recycle for the leach option UF recycle and the MOGC. Blending was conducted with $33 \%$ and $67 \%$ UF recycle by volume and with $33 \%$ and $55 \%$ MOGC, as shown in Table 6 . After blending, the slurries were placed on a shaker table and mixed at ambient temperature for a minimum of 7 days prior to sampling for physical properties and solids content. Since not all of the Envelope A tanks are $7 \mathrm{M}$, the matrix midpoint was tested at lower sodium concentration: 5.2M. The parameters for mixing these blends are shown in Table 7. As shown in Tables 6 and 7, the evaporation of recycle targeted values significantly below $5 \mathrm{M}$ sodium and in some cases dilution water was required in addition to the recycle volume. For the $7 \mathrm{M}$ blends, the maximum undissolved solids content was $2.1 \%$ and the average undissolved solids content was $0.5 \%$.

Table 6. Parameters for Blending of 7M Envelope A Waste Feed and Recycles.

\begin{tabular}{|l|c|c|c|c|c|c|c|c|}
\hline $\begin{array}{l}\text { Recycle } \\
\text { Type }\end{array}$ & $\begin{array}{c}\text { Recycle } \\
\text { Amount }\end{array}$ & $\begin{array}{c}\text { Waste } \\
\text { Feed } \\
\text { Amount }\end{array}$ & $\begin{array}{c}\text { Waste } \\
\text { Feed } \\
\text { Amount }\end{array}$ & $\begin{array}{c}\text { Initial } \\
\text { Amount of } \\
\text { Recycle }\end{array}$ & $\begin{array}{c}\text { Conc. } \\
\text { Recycle } \\
\text { Volume }\end{array}$ & $\begin{array}{c}\text { Initial } \\
\text { Molarity of } \\
\text { Recycle }\end{array}$ & $\begin{array}{c}\text { Final } \\
\text { Molarity of } \\
\text { Recycle }\end{array}$ & $\begin{array}{c}\text { Insoluble } \\
\text { Solids }\end{array}$ \\
\hline & Vol \% & Vol $\%$ & $\mathrm{ml}$ & $\mathrm{ml}$ & $\mathrm{ml}$ & molar & molar & wt \% \\
\hline UF1A & 33 & 67 & 63.0 & 31.5 & $36.5^{*}$ & 1.21 & 1.03 & 0.1 to 1.0 \\
\hline UF1A & 67 & 33 & 47.0 & 94.6 & 53.0 & 1.21 & 2.17 & 0.4 to 2.1 \\
\hline MOGC & 33 & 67 & 66.7 & 33.4 & 33.4 & 0.01 & 0.01 & 0.0 to 1.5 \\
\hline MOGC & 55 & 45 & 69.4 & 84.9 & 30.6 & 0.01 & 0.03 & 0.0 to 0.9 \\
\hline
\end{tabular}

* Dilution water required to reach target concentration.

Table 8. Parameters for Blending of 5.2M Envelope A Waste Feed and Recycles.

\begin{tabular}{|l|c|c|c|c|c|c|c|}
\hline Recycle & $\begin{array}{c}\text { Recycle } \\
\text { Amount }\end{array}$ & $\begin{array}{c}\text { Amount of } \\
\text { Waste Feed }\end{array}$ & $\begin{array}{c}\text { Initial } \\
\text { Amount of } \\
\text { Recycle }\end{array}$ & $\begin{array}{c}\text { Concentrated } \\
\text { Recycle } \\
\text { Volume }\end{array}$ & $\begin{array}{c}\text { Initial } \\
\text { Molarity of } \\
\text { Recycle }\end{array}$ & $\begin{array}{c}\text { Final } \\
\text { Molarity of } \\
\text { Recycle }\end{array}$ & $\begin{array}{c}\text { Insoluble } \\
\text { Solids }\end{array}$ \\
\hline & Volume $\%$ & $\mathrm{ml}$ & $\mathrm{ml}$ & $\mathrm{ml}$ & molar & molar & wt \% \\
\hline UF1A & 33 & 85.6 & 42.2 & 14.4 & 1.21 & 3.55 & 0.4 \\
\hline UF1A & 67 & 63.8 & 129.6 & 36.2 & 1.21 & 4.33 & 0.9 \\
\hline MOGC & 24.5 & 96.1 & 31.3 & 3.9 & 0.01 & 0.08 & 0.3 \\
\hline MOGC & 45.5 & 96.0 & 80.0 & 4.0 & 0.01 & 0.20 & 0.6 \\
\hline
\end{tabular}


WSRC-TR-2003-00212, Rev. 0

SRT-RPP-2003-00094, Rev. 0

\subsection{Evaporation and Blending of Envelope B Streams: AZ-102 Sludge Evaporation}

AZ-102 supernate contains approximately $2.7 \mathrm{M}$ sodium and requires concentration in the waste feed evaporator to meet the target density for feed to the ultrafiltration process. AZ-102 was evaporated starting with a solids loading of 3.5 and $7.5 \mathrm{wt} \%$ insoluble solids. Blends of AZ-102 and recycle were performed with 33\% and 67\% leach option recycle from the UF process and with $33 \%$ and $55 \%$ melter offgas condensate, as shown in Table 8 . The evaporation was conducted at 27 inches of mercury vacuum (1 psia) in a batch process using the apparatus shown in Appendix B. Samples were taken of the initial mixture and after evaporation.

Table 10. Evaporation Parameters for Envelope B Blends

\begin{tabular}{|l|c|c|c|c|c|c|c|c|}
\hline Run \# & $\begin{array}{c}\text { UF } \\
\text { Recycle } \\
\text { Amount }\end{array}$ & $\begin{array}{c}\text { MOGC } \\
\text { Amount }\end{array}$ & $\begin{array}{c}\text { Initial Na } \\
\text { Molarity }\end{array}$ & $\begin{array}{c}\text { Initial } \\
\text { Specific } \\
\text { Gravity } \\
\text { of } \\
\text { Slurry }\end{array}$ & $\begin{array}{c}\text { Initial } \\
\text { Temp } \\
\text { Vp=0.09 } \\
\text { bar }\end{array}$ & $\begin{array}{c}\text { Final Na } \\
\text { Molarity }\end{array}$ & $\begin{array}{c}\text { Final } \\
\text { Specific } \\
\text { Gravity } \\
\text { of } \\
\text { Slurry }\end{array}$ & $\begin{array}{c}\text { Final } \\
\text { Temp } \\
\text { Vp=0.09 } \\
\text { bar }\end{array}$ \\
\hline $\begin{array}{l}\text { AZ-102 } \\
3.5 \%\end{array}$ & 0 & 0 & 2.70 & 1.171 & 45.6 & 4.9 & 1.311 & 47.3 \\
\hline $\begin{array}{l}\text { AZ-102- } \\
33 \% \text { UF1B }\end{array}$ & 33 & 0 & 2.47 & 1.162 & 46.1 & 4.90 & 1.303 & 47.3 \\
\hline $\begin{array}{l}\text { AZ-102- } \\
67 \% \text { UF1B }\end{array}$ & 67 & 0 & 2.20 & 1.126 & 45.9 & 4.90 & 1.278 & 47.5 \\
\hline $\begin{array}{l}\text { AZ-102- } \\
33 \% \\
\text { MOGC }\end{array}$ & 0 & 33 & 1.82 & 1.123 & 45.6 & 4.80 & 1.326 & 47.1 \\
\hline $\begin{array}{l}\text { AZ-102- } \\
\text { 55\% } \\
\text { MOGC }\end{array}$ & 0 & 55 & 1.24 & 1.082 & 45.3 & 4.70 & 1.324 & 47.2 \\
\hline $\begin{array}{l}\text { AZ-102- } \\
7.5 \%-33 \% \\
\text { UF1 }\end{array}$ & 33 & 0 & 2.43 & 1.170 & 45.7 & 5.00 & 1.340 & 47.2 \\
\hline
\end{tabular}

Very little foaming was noted during the runs as shown in Appendix E, Figure E-2, but bumping was observed which became progressively worse as the sludge was concentrated. The amount of bumping was significantly worse than the bumping observed during recycle evaporation and led to a buildup of splatter on the vessel walls, as shown in Figure 8. 
WSRC-TR-2003-00212, Rev. 0

SRT-RPP-2003-00094, Rev. 0
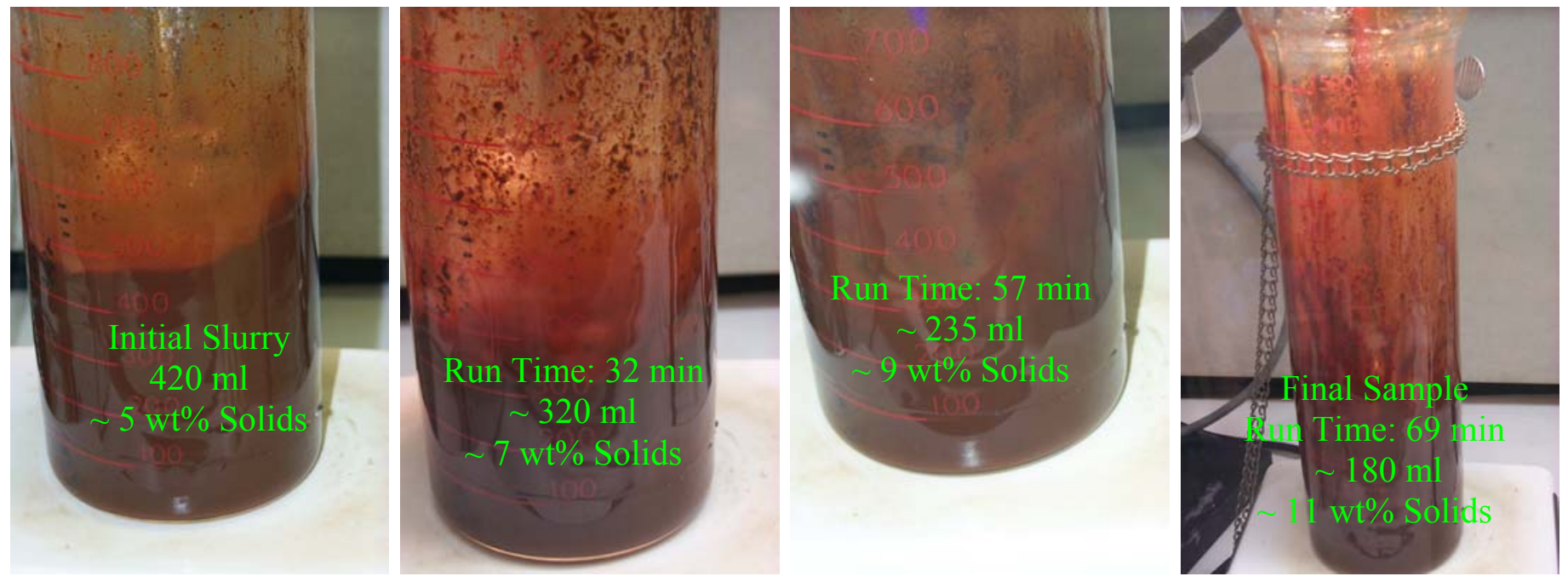

Figure 8. Splatter during Evaporation of AZ-102 w/ 33\% UF Recycle

The slurry viscosity, yield stress and weight \% solids of the final samples were measured, as shown in Figure 9. At 5M sodium concentration, the yield stress and viscosity begin to increase significantly above a solids content of $7 \mathrm{wt} \%$. As shown in Figure 8, splattering during the evaporation runs also significantly increased above a solids content of $7 \mathrm{wt} \%$ insoluble solids. Although bumping can be significantly decreased by increasing the vessel diameter, it will likely not be completely eliminated. The adhesion of the sludge to the vessel walls from the splatter due to bumping led to significantly higher amounts of scale on the walls after the runs with sludge than the other streams evaporated.
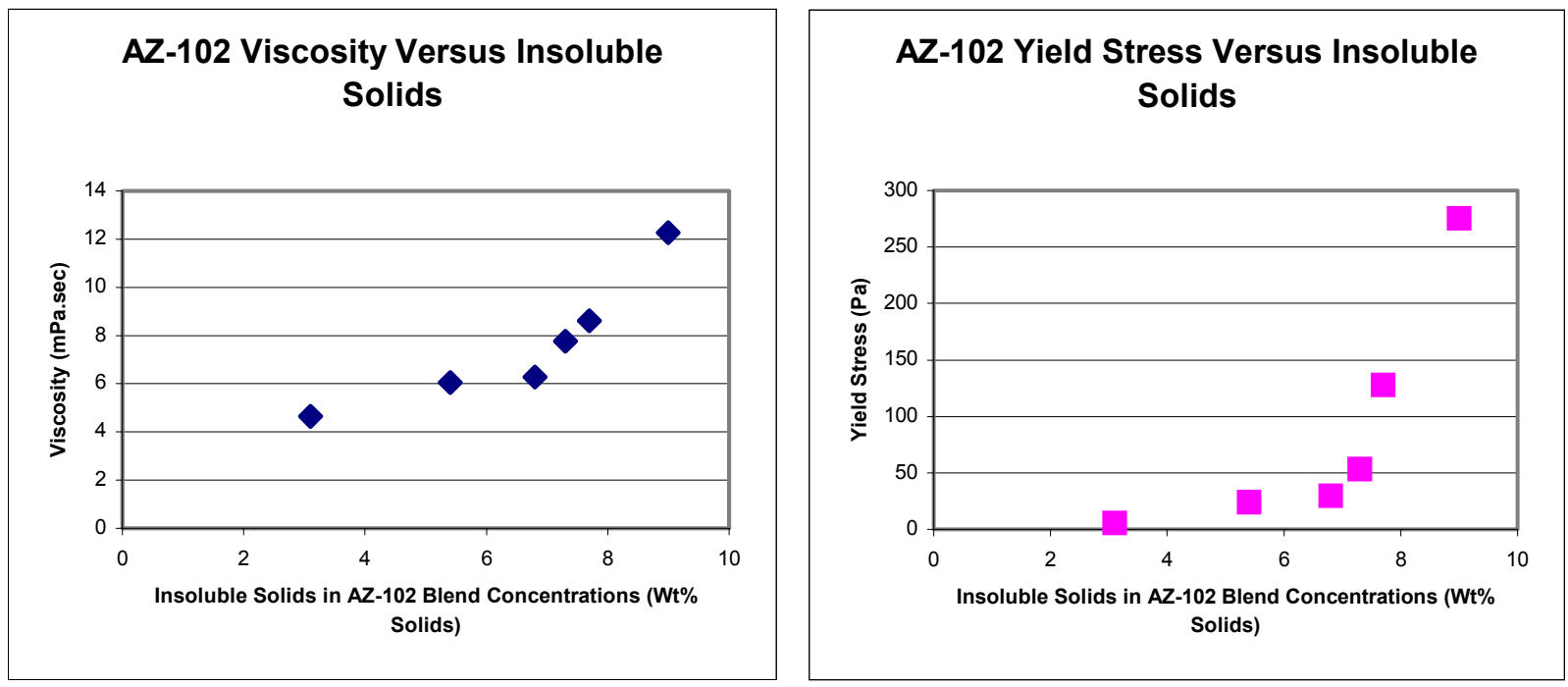

Figure 9. Viscosity and Yield Stress of AZ-102-Recycle Blends at $5 \mathrm{M} \mathrm{Na}$ at $25^{\circ} \mathrm{C}$ 


\subsection{Blending and Precipitation of Envelope C Streams}

All Envelope C waste feeds will bypass the waste feed evaporator since the sodium concentration of the feeds is greater than five molar. The recycle stream will be evaporated as required to dilute the waste feed to target a supernate specific gravity of 1.22. Blending of the waste feed with evaporated recycle was conducted for the no-leach option UF recycle and the melter offgas condensate. Blending was conducted with $33 \%$ and $67 \%$ UF recycle by volume and with $33 \%$ and $55 \%$ MOGC, as shown in Table 9.

Table 12. Parameters for Blending of Envelope C Waste Feed and Recycles

\begin{tabular}{|l|c|c|c|c|c|c|}
\hline Run Type & $\begin{array}{c}\text { Recycle } \\
\text { Amount }\end{array}$ & $\begin{array}{c}\text { Amount } \\
\text { of Waste } \\
\text { Feed }\end{array}$ & $\begin{array}{c}\text { Initial } \\
\text { Amount } \\
\text { of Recycle }\end{array}$ & $\begin{array}{c}\text { Concentrated } \\
\text { Recycle } \\
\text { Volume }\end{array}$ & $\begin{array}{c}\text { Initial } \\
\text { Molarity } \\
\text { of Recycle }\end{array}$ & $\begin{array}{c}\text { Final } \\
\text { Molarity } \\
\text { of Recycle }\end{array}$ \\
\hline & Vo1 \% & $\mathrm{ml}$ & $\mathrm{ml}$ & $\mathrm{ml}$ & molar & molar \\
\hline $\begin{array}{l}\text { AN-102 w/ } \\
33 \% \text { UF3C }\end{array}$ & 33 & 74.4 & 36.7 & 25.6 & 1.95 & 2.80 \\
\hline $\begin{array}{l}\text { AN-102 w/ } \\
67 \% \text { UF3C }\end{array}$ & 67 & 54.3 & 110.2 & 45.8 & 1.95 & 4.70 \\
\hline $\begin{array}{l}\text { AN-102 w/ } \\
33 \% \text { MOGC }\end{array}$ & 33 & 84.4 & 41.6 & 15.6 & 0.01 & 0.03 \\
\hline $\begin{array}{l}\text { AN-102 w/ } \\
55 \% \text { MOGC }\end{array}$ & 55 & 84.4 & 103.1 & 15.6 & 0.01 & 0.07 \\
\hline $\begin{array}{l}\text { AN-107 w/ } \\
33 \% \text { UF3C }\end{array}$ & 33 & 67 & 33 & 33 & 1.95 & 1.95 \\
\hline $\begin{array}{l}\text { AN-107 w/ } \\
67 \% \text { UF3C }\end{array}$ & 67 & 48.8 & 99.1 & 51.2 & 1.95 & 3.78 \\
\hline $\begin{array}{l}\text { AN-107 w/ } \\
33 \% \text { MOGC }\end{array}$ & 33 & 72 & 35.5 & 28.0 & 0.01 & 0.01 \\
\hline $\begin{array}{l}\text { AN-107 w/ } \\
55 \% \text { MOGC }\end{array}$ & 55 & 71.9 & 87.9 & 28.1 & 0.01 & 0.03 \\
\hline
\end{tabular}

Volume fractions represent the volumes of the recycle prior to evaporation. A calculation was performed to determine what concentration the recycle must be in order to dilute the waste feeds to target $6 \mathrm{M}$ sodium content. In one case, the calculation showed that concentration of the recycle was not required. After blending with the recycle, the blends streams were held at ambient temperature in a shaker table for one week prior to sampling for physical properties and solids content.

The blended streams as well as AN-102 and AN-107 waste feeds without recycle then underwent a precipitation process using the steps shown below. The apparatus, as shown in Appendix B, consisted of jacketed $100 \mathrm{ml}$ beakers and syringes to meter out the required amount of each chemical. The chemicals were added incrementally by addition of a small portion of the required amount each minute over the time periods specified. 
1. Heat solution to $50^{\circ}$ Celsius.

2. Adjust hydroxide concentration with $50 \% \mathrm{NaOH}$ to $1 \mathrm{M}$ over a ten minute time period.

3. Mix for 15 minutes.

4. Add $2 \mathrm{M} \mathrm{Sr}\left(\mathrm{NO}_{3}\right)_{2}$ solution to a target $\mathrm{Sr}$ concentration of $0.075 \mathrm{M}$ over a period of twenty minutes.

5. Mix for 15 minutes.

6. Add $1 \mathrm{M} \mathrm{NaMnO}_{4}$ solution to add $\mathrm{NaMnO}_{4}$ concentration of $0.05 \mathrm{M}$ over a period of twenty minutes.

7. Cover beakers with watch glasses.

8. Mix for 4 hours at 50 degrees Celsius.

9. Continue mixing slurries while allowing to cool.

10. Sample slurries.

Density analysis was performed on the samples after precipitation. The density results exceeded the target of 1.22, therefore the amount of dilution water that was required was calculated. Water was then added to the samples prior to testing for density, as shown in Table 10.

Table 15. Amount of Water Added to Envelope C Blends

\begin{tabular}{|l|c|c|c|c|c|c|c|c|}
\hline $\begin{array}{l}\text { Waste } \\
\text { Feed }\end{array}$ & Recycle & $\begin{array}{l}\text { Initial Na } \\
\text { Molarity }\end{array}$ & $\begin{array}{l}\text { Solution } \\
\text { Weight }\end{array}$ & Density & $\begin{array}{c}\text { Sample } \\
\text { Volume }\end{array}$ & $\begin{array}{c}\text { Water } \\
\text { Addition }\end{array}$ & $\begin{array}{c}\text { Final Na } \\
\text { Molarity }\end{array}$ & $\begin{array}{c}\text { Density } \\
\text { after } \\
\text { Dilution }\end{array}$ \\
\hline & & molar & grams & $\mathrm{g} / \mathrm{ml}$ & $\mathrm{ml}$ & grams & molar & $\mathrm{g} / \mathrm{ml}$ \\
\hline AN-102 & $33 \%$ UF3C & 6.11 & 47.97 & 1.309 & 36.64 & 14.75 & 4.36 & 1.228 \\
\hline AN-102 & $67 \%$ UF3C & 5.99 & 48.70 & 1.314 & 37.06 & 15.73 & 4.20 & 1.229 \\
\hline AN-102 & $33 \%$ MOGC & 6.36 & 47.66 & 1.317 & 36.20 & 15.72 & 4.43 & 1.229 \\
\hline AN-102 & $55 \%$ MOGC & 5.98 & 48.92 & 1.317 & 37.15 & 16.23 & 4.16 & 1.229 \\
\hline AN-107 & $33 \%$ UF3C & 6.41 & 56.63 & 1.332 & 42.53 & 21.56 & 4.26 & 1.230 \\
\hline AN-107 & $67 \%$ UF3C & 6.17 & 55.28 & 1.312 & 42.15 & 17.50 & 4.36 & 1.228 \\
\hline AN-107 & $33 \%$ MOGC & 6.43 & 53.56 & 1.320 & 40.57 & 18.45 & 4.42 & 1.229 \\
\hline AN-107 & $55 \%$ MOGC & 6.15 & 51.58 & 1.318 & 39.13 & 17.46 & 4.25 & 1.229 \\
\hline AN-102 & none & 5.98 & 67.76 & 1.304 & 51.94 & 19.90 & 4.33 & 1.228 \\
\hline AN-107 & none & 6.15 & 66.39 & 1.317 & 50.39 & 22.26 & 4.27 & 1.229 \\
\hline
\end{tabular}

\subsection{Mercury Speciation Tests}

Tests were conducted to determine the fate of mercury during the waste feed evaporation process. Envelope A simulants were chosen for the evaporation tests to avoid the potential for formation of dimethyl mercury. Performing the tests with solutions that could potentially form dimethyl mercury would have required an extensive safety review and was not possible given the budget and schedule requirements. Two Envelope A simulants diluted to 2.7M (SM-03 and SM06) along with the AZ-102 simulant were spiked with 200 ppm mercury as mercuric nitrate. The sample results from C-106/AY-102 were the basis for the 200 ppm mercury concentration. Samples were then taken of the mixtures and analysis performed to determine the amount of mercury in the supernate versus the amount in the slurry to determine the amount of soluble 
versus insoluble mercury present. Atomic absorption was utilized to perform the mercury analysis. The Envelope A simulants results indicated that a significant portion of the mercury was soluble while a much smaller percentage was soluble for the AZ-102 slurry, as shown in Table 11.

Table 16. Soluble Mercury in Initial Samples

\begin{tabular}{|l|l|l|l|}
\hline Simulant & $\begin{array}{l}\text { Total Amount of } \\
\text { Mercury }\end{array}$ & $\begin{array}{l}\text { Amount of Mercury } \\
\text { in Supernate }\end{array}$ & $\begin{array}{l}\text { Soluble mercury } \\
\text { percentage }\end{array}$ \\
\hline & ppm & ppm & \% of Total Mercury \\
\hline SM-03 & $200^{*}$ & 71.9 & 36.0 \\
\hline SM-06 & $200^{*}$ & 59.3 & 30.0 \\
\hline AZ-102 & 204.3 & 13.0 & 6.4 \\
\hline
\end{tabular}

* See discussion of Envelope A sample results below.

The Envelope A simulants were then evaporated to $5 \mathrm{M}$ sodium in the apparatus as shown in Appendix B. The apparatus consisted of an evaporation vessel, an initial condensor maintained at 30 degrees Celsius, a secondary condensor maintained at 5 degrees Celsius, an activated carbon trap on the exhaust and a vacuum pump and bleed valve. The evaporation was conducted at 27 inches $\mathrm{Hg}$ vacuum and at a low flux rate $(\sim 1 \mathrm{ml} / \mathrm{min})$ to allow an 8 hour residence time in the evaporation vessel without reflux. The temperature of the evaporation was approximately 40 degrees at the start of the run and increased to approximately 45 degrees during the run. After evaporation, the concentrated slurry was sampled in the same manner as the initial mixture. Samples were also taken of the condensate generated by each run. All samples were submitted in triplicate and the results were averaged.

The evaporation process increased the amount of soluble mercury present in the samples as shown by Table 12. As shown in Table 13, the soluble mercury species did not evaporate as elemental mercury into the offgas system since no mercury was detected in the condensate samples from either run or the activated carbon trap utilized for both runs. Mercury was less than detectable in all samples from the offgas system.

Table 17. Soluble Mercury After Evaporation

\begin{tabular}{|l|c|c|c|}
\hline Simulant & $\begin{array}{c}\text { Total Amount of } \\
\text { Mercury }\end{array}$ & $\begin{array}{c}\text { Amount of Mercury } \\
\text { in Supernate }\end{array}$ & $\begin{array}{c}\text { Soluble mercury } \\
\text { percentage }\end{array}$ \\
\hline & $\mathrm{ppm}$ & $\mathrm{ppm}$ & $\%$ of Total Mercury \\
\hline SM-03 & $370^{*}$ & 250.7 & 67.8 \\
\hline SM-06 & $370^{*}$ & 169.0 & 45.7 \\
\hline
\end{tabular}

*See discussion of Envelope A sample results below.

Table 18. Mercury in Evaporator Offgas System

\begin{tabular}{|l|c|}
\hline Simulant & Mercury \\
\hline SM-03 Condensate & ppm \\
\hline SM-06 Condensate & $<1.2$ \\
\hline Carbon trap & $<1.2$ \\
\hline
\end{tabular}


The amount of mercury in the samples was measured after solids dissolution for the slurry samples. The results for AZ-102 indicated good agreement with the amount of mercury added, but the results for the Envelope A samples was significantly lower than the $200 \mathrm{ppm}$ targeted. The calculations and additions were reviewed and no errors were noted. Problems have occurred in past samples with mercury chlorides not dissolving and significantly more chloride is present in the Envelope A samples than in the AZ-102 sample. Targeted mercury values were used in place of the sample results for the Envelope A total sample results. Supernate samples were not impacted as insoluble species were not present.

\subsection{Filtration of Envelope A Waste Blends}

The impact of recycle on the ultrafiltration process was assessed by performing tests on Envelope A waste feeds and recycles. Envelope A was chosen for the tests for the following reasons: the recycle from Envelope A contained the most solids, Envelope B contained so many solids in the waste feed that the impact of recycle could be swamped, and the precipitation steps to produce Envelope $\mathrm{C}$ feed would have increased the time required to produce the simulants.

The first waste feed was a blend of Envelope A matrix points SM-02 and SM-08 while the second feed was a blend of SM-01 and SM-07. These two solutions were selected based on insoluble solids content. The SM-02/SM-08 blend was low in aluminum and had very little insoluble solids while SM-01/SM-07 was high in aluminum and had significantly more insoluble solids than the low aluminum blend. The $7 \mathrm{M}$ waste feed was diluted with DI water to $5 \mathrm{M}$ for the waste only tests.

The recycle tested was a 50/50 mixture of UF recycle from the leach option and melter offgas condensate. The recycle was added to the $7 \mathrm{M}$ waste feed in the amount required to dilute the waste feed to $5 \mathrm{M}$, therefore, no evaporation was required of the recycle. The initial permeate flux from the filter was measured for water, each waste blend without recycle, and each waste blend with recycle added.

The cross-flow filter utilized was a 6 " long MOTT filter with a 0.5 micron pore size. A centrifugal pump was utilized which provided approximately 4 GPM of flow and 20 psig of back pressure on the system. The permeate was recycled back to the feed tank to allow the permeate flux to be measured multiple times at the same solids loading. The permeate flux was measured by timing the accumulation of $40 \mathrm{ml}$ of permeate. The accumulated permeate was added back to the feed vessel after the timing process was completed. After taking readings for 30 minutes, $100 \mathrm{ml}$ of permeate was removed and the permeate flux was again measured. The experimental apparatus is shown in Appendix B.

The results of the filtration tests indicated that addition of recycle to the waste feed significantly impacts the permeate flux rate. As shown in Table 14 and Figure 10, the initial flux rates for runs with recycle were approximately $1 / 2$ to $1 / 3$ the flux rates without recycle. No back-pulsing was performed during the tests, the increase in flux at a time of 30 minutes is the result of deadheading the filter to change from refluxing to drawing off $100 \mathrm{ml}$ of permeate. It should be 
WSRC-TR-2003-00212, Rev. 0

SRT-RPP-2003-00094, Rev. 0

noted that the flux rates should not be compared to design basis values as the pore size of the filter was not prototypical and only the initial permeate flux was measured.

Table 19. Parameters and Results for Filtration Tests

\begin{tabular}{|l|c|c|c|}
\hline Run Number & Insoluble Solids & $\begin{array}{c}\text { Initial Permeate Flux } \\
\text { Rate }\end{array}$ & $\begin{array}{c}\text { Final Permeate Flux } \\
\text { Rate }\end{array}$ \\
\hline & wt \% & $\mathrm{ml} / \mathrm{min}$ & $\mathrm{ml} / \mathrm{min}$ \\
\hline SM-02/08 & 0.33 & 126 & 67 \\
\hline SM-02/08 w/ recycle & 2.30 & 45 & 16 \\
\hline SM-01/07 & 1.31 & 75 & 41 \\
\hline SM-01/07 w/ recycle & 3.00 & 30 & 12 \\
\hline
\end{tabular}

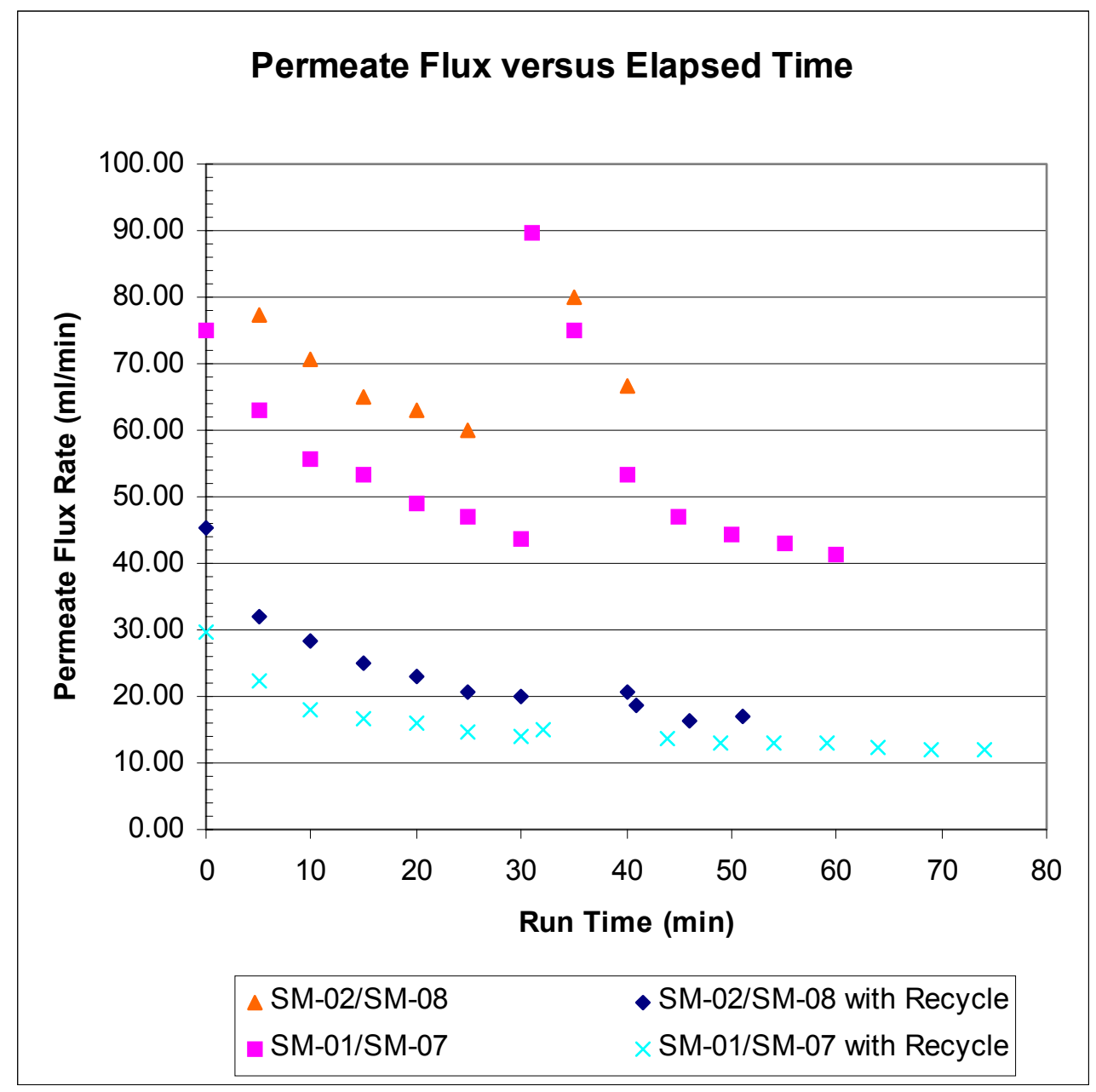

Figure 10. Filtration Flux Rates

The amount of insoluble solids in the feed stream varied significantly during the runs. Addition of the UF recycle to the waste feed simulant resulted in an increase in the insoluble solids. The initial and final permeate fluxes were plotted versus insoluble solids percentage to determine if the decrease in flux was primarily a factor of the increase in solids or if the solids in the UF recycle were more difficult to filter than the waste feed solids. As shown in Figure 11, the filter 
WSRC-TR-2003-00212, Rev. 0

SRT-RPP-2003-00094, Rev. 0

flux showed a correlation with solids loading, indicating that the primary impact of UF recycle on the filtration process is the increase in solids loading.

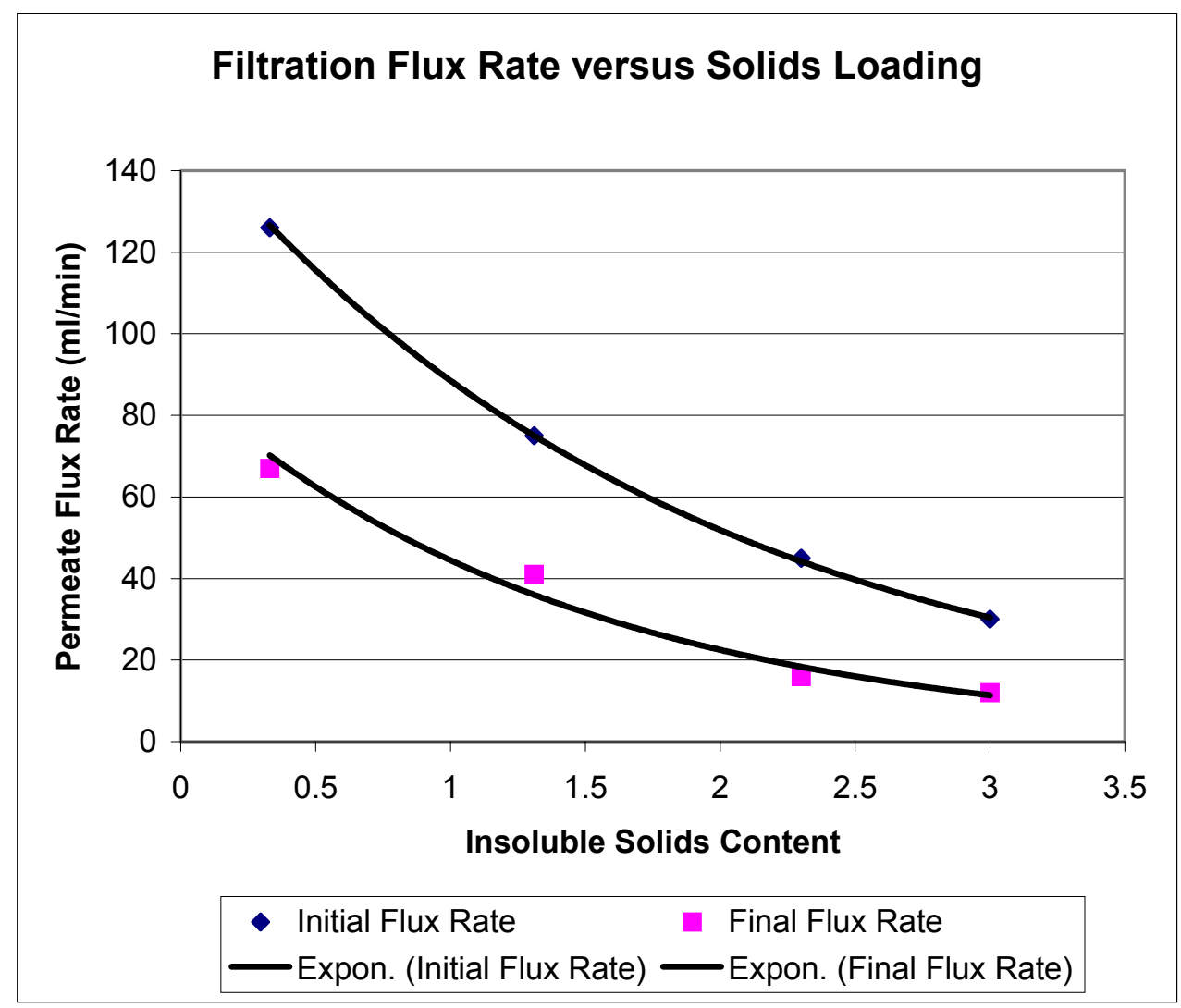

Figure 11. Filtration Flux Versus Insoluble Solids

\subsection{Bulk Solubility of Recycle and Blended Streams}

The amount of solids present in each recycle were measured and the solids were characterized by X-ray Diffraction (XRD) before and after evaporation. The amount of solids was utilized to determine the extent of precipitation, if any, that occurred during evaporation. The XRD technique will detect species that represent at least $1 \%$ of the solids present, but species below that level can be masked by the other solids. In addition, the amount and type of solids was measured after the recycle was blended with the waste feeds.

\subsubsection{Recycle Solubility and Solids Characterization}

Envelope A recycles contained aluminum hydroxides (gibbsite and bayerite) and corundum $\left(\mathrm{Al}_{2} \mathrm{O}_{3}\right)$ as well as reevesite $\left(\mathrm{Ni}_{6} \mathrm{Fe}_{2}\left(\mathrm{CO}_{3}\right)(\mathrm{OH}) 4 \mathrm{H}_{2} \mathrm{O}\right)$ and sodium carbonate hydrate prior to evaporation. The XRD for concentrated recycle did not indicate the presence of quartz, corundum, or reevesite, therefore these solids were either dissolved or masked by the presence of

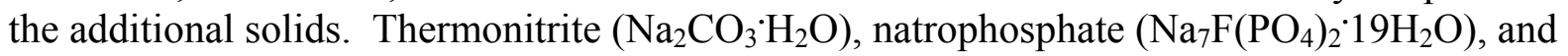
natroxalate $\left(\mathrm{Na}_{2} \mathrm{C}_{2} \mathrm{O}_{4}\right)$ were present in most of the concentrated recycle streams, in addition to gibbsite and bayerite. Lithium aluminum carbonate hydroxide hydrate $\left(\left(\mathrm{Al}_{2} \mathrm{Li}(\mathrm{OH})_{6}\right)_{2}\right.$ 
$\mathrm{CO}_{3} \cdot \mathrm{xH}_{2} \mathrm{O}$ ) was present in most samples that contained MOGC. As shown in Table 15, the evaporator feed contained 0.2 to 0.5 weight percent insoluble solids while the concentrate contained 2.1 to $3.7 \%$. When the volume reduction of the feed is taken into account, approximately $0.5 \mathrm{wt} \%$ of solids were precipitated from each sample.

Table 20. Insoluble Solids in Envelope A Recycle Evaporation Runs

\begin{tabular}{|c|c|c|c|c|}
\hline UF Recycle & $\begin{array}{l}\text { MOGC } \\
\text { Amount }\end{array}$ & $\begin{array}{l}\text { Initial } \\
\text { Solids }\end{array}$ & $\begin{array}{l}\text { Final } \\
\text { Solids }\end{array}$ & Solids Present after Evaporation \\
\hline & Vol \% & wt \% & wt $\%$ & \\
\hline UF1A & 0 & 0.3 & 3.2 & $\begin{array}{l}\text { Gibbsite, bayerite, sodium carbonate } \\
\text { hydrate, natrophosphate }\end{array}$ \\
\hline UF1A & 25 & 0.4 & 2.7 & $\begin{array}{l}\text { Gibbsite, bayerite, sodium carbonate } \\
\text { hydrate, natrophosphate }\end{array}$ \\
\hline UF1A & 50 & 0.5 & 2.7 & $\begin{array}{l}\text { Gibbsite, bayerite, natrophosphate, } \\
\text { lithium aluminum hydroxide hydrate }\end{array}$ \\
\hline UF1A & 75 & 0.3 & 3.7 & $\begin{array}{l}\text { Gibbsite, bayerite, sodium strontium } \\
\text { phosphate hydrate, lithium aluminum } \\
\text { hydroxide hydrate, Zeolite } A^{*}\end{array}$ \\
\hline UF2A & 25 & 0.0 & 0.2 & $\begin{array}{l}\text { Sodium carbonate hydrate, } \\
\text { natrophosphate }\end{array}$ \\
\hline UF3A & 0 & 0.3 & 2.1 & $\begin{array}{l}\text { Gibbsite, bayerite, sodium carbonate } \\
\text { hydrate, natrophosphate }\end{array}$ \\
\hline UF3A & 25 & 0.2 & 2.1 & $\begin{array}{l}\text { Gibbsite, bayerite, sodium carbonate } \\
\text { hydrate, natrophosphate, lithium } \\
\text { aluminum hydroxide hydrate }\end{array}$ \\
\hline UF3A & 50 & 0.2 & 2.5 & $\begin{array}{l}\text { Gibbsite, bayerite, natrophosphate, } \\
\text { lithium aluminum hydroxide hydrate }\end{array}$ \\
\hline UF3A & 75 & 0.2 & 2.9 & $\begin{array}{c}\text { Gibbsite, bayerite, lithium aluminum } \\
\text { hydroxide hydrate }\end{array}$ \\
\hline
\end{tabular}

* Questionable peak

Envelope B recycles contained significantly less solids after blending than Envelope A, as shown in Table 16. It should be noted that the same solutions were used for the Envelope B recycle as Envelope A, except for the UF $1^{\text {st }}$ wash. The evaporator feed typically contained 0.05 weight percent insoluble solids while the concentrate typically contained 0.5 to $0.6 \%$. A comparison of the compositions shows that Envelope B recycle contained significantly less aluminum and more hydroxide than the Envelope A recycle. The only solids present prior to evaporation were quartz solids from the MOGC. After evaporation, both recycles contained sodium oxalate $\left(\mathrm{Na}_{2} \mathrm{C}_{2} \mathrm{O}_{4}\right)$, sodium nitrate $\left(\mathrm{NaNO}_{3}\right)$, and corundum $\left(\mathrm{Al}_{2} \mathrm{O}_{3}\right)$ while the UF1B sample without MOGC also contained sodium carbonate hydrate $\left(\mathrm{Na}_{2} \mathrm{CO}_{3} \cdot \mathrm{H} 2 \mathrm{O}\right)$. 
WSRC-TR-2003-00212, Rev. 0

SRT-RPP-2003-00094, Rev. 0

Table 21. Insoluble Solids in Envelope B Recycle Evaporation Runs

\begin{tabular}{|l|c|c|c|c|}
\hline UF Recycle & $\begin{array}{c}\text { MOGC } \\
\text { Amount }\end{array}$ & $\begin{array}{c}\text { Initial } \\
\text { Solids }\end{array}$ & $\begin{array}{c}\text { Final } \\
\text { Solids }\end{array}$ & Solids Present after Evaporation \\
\hline UF1B & Vol \% & $\mathrm{wt} \mathrm{\%}$ & wt \% & \\
\hline UF1B & 0 & 0.1 & 0.4 & $\begin{array}{c}\text { Corundum, sodium carbonate hydrate, } \\
\text { sodium oxalate }\end{array}$ \\
\hline
\end{tabular}

Envelope $\mathrm{C}$ recycle from the UF process contained sodium strontium phosphate hydrate, as discussed below. The amounts of insoluble solids present before and after evaporation are shown in Table 17. The final solids value has not been adjusted for the volume reduction that occurred during evaporation. When the value is adjusted, the results indicate that the amount of insoluble solids was reduced by evaporation, but this result is within the error of the measurement. The UF3C final sample without MOGC indicated the presence of natrophosphate $\left(\mathrm{Na}_{7} \mathrm{~F}\left(\mathrm{PO}_{4}\right)_{2} \cdot 19 \mathrm{H}_{2} \mathrm{O}\right)$, but the other 3 samples only contained sodium strontium phosphate hydrate.

Table 22. Insoluble Solids in Envelope C Recycle Evaporation Runs

\begin{tabular}{|l|c|c|c|c|}
\hline UF Recycle & $\begin{array}{c}\text { MOGC } \\
\text { Amount }\end{array}$ & $\begin{array}{c}\text { Initial } \\
\text { Solids }\end{array}$ & $\begin{array}{c}\text { Final } \\
\text { Solids }\end{array}$ & Solids Present after Evaporation \\
\hline & Vol \% & wt \% & wt \% & \\
\hline UF3C & 0 & 0.2 & 0.3 & $\begin{array}{c}\text { Sodium strontium phosphate hydrate, } \\
\text { natrophosphate }\end{array}$ \\
\hline UF3C & 50 & 0.3 & 0.7 & Sodium strontium phosphate hydrate \\
\hline
\end{tabular}

\subsubsection{Waste Feed / Recycle Blend Solids Characterization}

Solids formed after blending the waste feed with recycle were characterized by XRD, as shown in Tables 18, 19 and 20. New solids were not typically present after blending, with the exception of Zeolite A that formed in Envelope A samples. Some solids present in the recycle and waste feed before blending were not noted in the blends, most likely the result of masking of the presence of a small solids components by the larger amount of solids in the combined stream. 
WSRC-TR-2003-00212, Rev. 0

SRT-RPP-2003-00094, Rev. 0

Table 23. Solids in Waste Feed - Recycle Blends: Envelope A

\begin{tabular}{|c|c|c|c|c|c|}
\hline Simulant & $\begin{array}{l}\text { Solids in Waste } \\
\text { Feed }\end{array}$ & $\begin{array}{l}\text { Solids in Blends } \\
\text { with } 33 \% \\
\text { UF1A }\end{array}$ & $\begin{array}{l}\text { Solids in } \\
\text { Blends with } \\
67 \% \text { UF } 1 \mathrm{~A}\end{array}$ & $\begin{array}{l}\text { Solids in } \\
\text { Blends with } \\
33 \% \mathrm{MOGC}\end{array}$ & $\begin{array}{l}\text { Solids in } \\
\text { Blends with } \\
55 \% \mathrm{MOGC}\end{array}$ \\
\hline SM-01 & $\begin{array}{l}\text { Sodium carbonate } \\
\text { hydrate } \\
\text { Bayerite }\end{array}$ & $\begin{array}{l}\text { Sodium carbonate } \\
\text { hydrate } \\
\text { Bayerite } \\
\text { Gibbsite }\end{array}$ & $\begin{array}{l}\text { Sodium carbonate } \\
\text { hydrate } \\
\text { Bayerite } \\
\text { Gibbsite } \\
\text { Corundum }\end{array}$ & $\begin{array}{l}\text { Sodium carbonate } \\
\text { hydrate } \\
\text { Bayerite } \\
\text { Quartz }\end{array}$ & $\begin{array}{l}\text { Sodium carbonate } \\
\text { hydrate } \\
\text { Bayerite } \\
\text { Gibbsite } \\
\text { Quartz }\end{array}$ \\
\hline SM-02 & $\begin{array}{l}\mathrm{Na}_{3} \mathrm{FSO}_{4}, \mathrm{NaF} \\
\text { Sodium oxalate }\end{array}$ & $\begin{array}{l}\text { Bayerite, } \mathrm{NaF} \\
\text { Sodium oxalate } \\
\text { Gibbsite } \\
\text { Zeolite A }\end{array}$ & $\begin{array}{l}\text { Sodium carbonate } \\
\text { hydrate } \\
\text { Bayerite } \\
\text { Sodium oxalate } \\
\text { Gibbsite } \\
\text { Zeolite A }\end{array}$ & $\begin{array}{l}\text { Sodium carbonate } \\
\text { hydrate } \\
\text { Bayerite, NaF } \\
\text { Sodium oxalate } \\
\text { Zeolite A } \\
\text { Quartz }\end{array}$ & $\begin{array}{l}\text { Bayerite, NaF } \\
\text { Sodium oxalate } \\
\text { Zeolite A } \\
\text { Quartz }\end{array}$ \\
\hline SM-03 & $\begin{array}{l}\text { Sodium oxalate } \\
\text { Natrophospate }\end{array}$ & $\begin{array}{l}\text { Sodium carbonate } \\
\text { hydrate } \\
\text { Bayerite } \\
\text { Gibbsite } \\
\text { Zeolite A }\end{array}$ & $\begin{array}{l}\text { Bayerite } \\
\text { Sodium oxalate } \\
\text { Gibbsite } \\
\text { Zeolite A } \\
\text { Corundum } \\
\text { Sodium aluminate }\end{array}$ & $\begin{array}{l}\text { Sodium carbonate } \\
\text { hydrate } \\
\text { Bayerite } \\
\text { Zeolite A } \\
\text { Quartz }\end{array}$ & $\begin{array}{l}\text { Sodium carbonate } \\
\text { hydrate } \\
\text { Bayerite } \\
\text { Zeolite A } \\
\text { Quartz }\end{array}$ \\
\hline SM-04 & $\begin{array}{l}\mathrm{NaF} \\
\text { Natrophospate } \\
\text { Sodium oxalate }\end{array}$ & $\begin{array}{l}\text { Sodium oxalate } \\
\text { Natrophospate }\end{array}$ & $\begin{array}{l}\text { Sodium carbonate } \\
\text { hydrate } \\
\text { Bayerite } \\
\text { Sodium oxalate } \\
\text { Natrophospate } \\
\text { Gibbsite }\end{array}$ & $\begin{array}{l}\text { Sodium oxalate } \\
\text { Natrophospate }\end{array}$ & $\begin{array}{l}\text { Sodium oxalate } \\
\text { Natrophospate }\end{array}$ \\
\hline SM-05 & $\begin{array}{l}\text { Sodium carbonate } \\
\text { hydrate }\end{array}$ & $\begin{array}{l}\text { Sodium carbonate } \\
\text { hydrate } \\
\text { Bayerite } \\
\text { Gibbsite }\end{array}$ & $\begin{array}{l}\text { Sodium carbonate } \\
\text { hydrate } \\
\text { Bayerite } \\
\text { Gibbsite }\end{array}$ & $\begin{array}{l}\text { Amorphous -no } \\
\text { species identified }\end{array}$ & $\mathrm{NaF}$ \\
\hline SM-06 & $\begin{array}{l}\text { Sodium oxalate } \\
\text { Natrophospate }\end{array}$ & $\begin{array}{l}\text { Sodium carbonate } \\
\text { hydrate } \\
\text { Bayerite } \\
\text { Gibbsite } \\
\text { Zeolite A }\end{array}$ & $\begin{array}{l}\text { Sodium carbonate } \\
\text { hydrate } \\
\text { Bayerite } \\
\text { Gibbsite } \\
\text { Zeolite A } \\
\text { Corundum } \\
\text { Sodium aluminate }\end{array}$ & $\begin{array}{l}\text { Sodium carbonate } \\
\text { hydrate } \\
\text { Bayerite } \\
\text { Zeolite A }\end{array}$ & $\begin{array}{l}\text { Sodium carbonate } \\
\text { hydrate } \\
\text { Bayerite } \\
\text { Zeolite A } \\
\text { Quartz }\end{array}$ \\
\hline SM-07 & $\begin{array}{l}\text { Sodium oxalate } \\
\text { Natrophospate }\end{array}$ & $\begin{array}{l}\text { Sodium oxalate } \\
\text { Natrophospate }\end{array}$ & $\begin{array}{l}\text { Bayerite } \\
\text { Sodium oxalate } \\
\text { Natrophospate } \\
\text { Gibbsite } \\
\text { Sodium aluminate }\end{array}$ & $\begin{array}{l}\text { Sodium carbonate } \\
\text { hydrate } \\
\text { Bayerite } \\
\text { Sodium oxalate } \\
\text { Natrophospate } \\
\text { Quartz }\end{array}$ & $\begin{array}{l}\text { Bayerite } \\
\text { Sodium oxalate } \\
\text { Natrophospate }\end{array}$ \\
\hline SM-08 & $\begin{array}{l}\text { Sodium carbonate } \\
\text { hydrate } \\
\text { Sodium oxalate }\end{array}$ & $\begin{array}{l}\text { Sodium carbonate } \\
\text { hydrate } \\
\text { Bayerite } \\
\text { Sodium oxalate } \\
\text { Gibbsite } \\
\text { Zeolite A }\end{array}$ & $\begin{array}{l}\text { Bayerite } \\
\text { Sodium oxalate } \\
\text { Gibbsite } \\
\text { Zeolite A } \\
\text { Corundum }\end{array}$ & $\begin{array}{l}\text { Sodium carbonate } \\
\text { hydrate } \\
\text { Bayerite } \\
\text { Zeolite A } \\
\text { Quartz }\end{array}$ & $\begin{array}{l}\text { Sodium oxalate } \\
\text { Zeolite A } \\
\text { Quartz }\end{array}$ \\
\hline SM-09 & $\begin{array}{l}\mathrm{Na}_{3} \mathrm{FSO}_{4}, \mathrm{NaF} \\
\text { Sodium oxalate }\end{array}$ & $\begin{array}{l}\text { Bayerite, } \mathrm{NaF} \\
\text { Gibbsite }\end{array}$ & $\begin{array}{l}\text { Sodium carbonate } \\
\text { hydrate }\end{array}$ & $\begin{array}{l}\text { Sodium carbonate } \\
\text { hydrate }\end{array}$ & $\begin{array}{l}\text { Bayerite, } \mathrm{NaF} \\
\text { Quartz }\end{array}$ \\
\hline
\end{tabular}


WSRC-TR-2003-00212, Rev. 0

SRT-RPP-2003-00094, Rev. 0

\begin{tabular}{|c|c|c|c|c|c|}
\hline & Natrophospate & & $\begin{array}{l}\text { Bayerite, } \mathrm{NaF} \\
\text { Gibbsite }\end{array}$ & $\begin{array}{l}\text { Bayerite, } \mathrm{NaF} \\
\text { Quartz }\end{array}$ & \\
\hline SM-10 & $\begin{array}{l}\mathrm{NaF} \\
\text { Sodium oxalate } \\
\text { Natrophospate }\end{array}$ & $\begin{array}{l}\text { Sodium carbonate } \\
\text { hydrate } \\
\text { Bayerite, } \mathrm{NaF} \\
\text { Gibbsite }\end{array}$ & $\begin{array}{l}\text { Sodium carbonate } \\
\text { hydrate } \\
\text { Bayerite } \\
\text { Gibbsite } \\
\text { Corundum }\end{array}$ & $\begin{array}{l}\text { Sodium carbonate } \\
\text { hydrate } \\
\text { Bayerite, } \mathrm{NaF} \\
\text { Quartz }\end{array}$ & $\begin{array}{l}\text { Sodium carbonate } \\
\text { hydrate } \\
\text { Bayerite, } \mathrm{NaF} \\
\text { Gibbsite } \\
\text { Quartz } \\
\end{array}$ \\
\hline SM-11 & $\begin{array}{l}\text { Sodium oxalate } \\
\text { Natrophospate }\end{array}$ & $\begin{array}{l}\text { Sodium carbonate } \\
\text { hydrate } \\
\text { Bayerite } \\
\text { Sodium oxalate } \\
\text { Natrophospate }\end{array}$ & $\begin{array}{l}\text { Bayerite } \\
\text { Sodium oxalate } \\
\text { Natrophospate } \\
\text { Gibbsite } \\
\text { Corundum } \\
\text { Sodium aluminate }\end{array}$ & $\begin{array}{l}\text { Sodium oxalate } \\
\text { Natrophospate }\end{array}$ & $\begin{array}{l}\text { Sodium oxalate } \\
\text { Natrophospate }\end{array}$ \\
\hline SM-12 & $\begin{array}{l}\text { Sodium oxalate } \\
\text { Natrophospate }\end{array}$ & $\begin{array}{l}\text { Sodium carbonate } \\
\text { hydrate } \\
\text { Bayerite } \\
\text { Natrophospate } \\
\text { Gibbsite }\end{array}$ & $\begin{array}{l}\text { Bayerite } \\
\text { Sodium oxalate } \\
\text { Natrophospate } \\
\text { Gibbsite }\end{array}$ & $\begin{array}{l}\text { Sodium carbonate } \\
\text { hydrate } \\
\text { Sodium oxalate } \\
\text { Natrophospate } \\
\text { Quartz }\end{array}$ & $\begin{array}{l}\text { Sodium oxalate } \\
\text { Natrophospate }\end{array}$ \\
\hline $\begin{array}{l}\mathrm{SM}-11 \\
\text { (a) } 5.2 \mathrm{M}\end{array}$ & $\begin{array}{l}\mathrm{NaF} \\
\text { Natrophospate }\end{array}$ & $\begin{array}{l}\text { Natrophospate } \\
\text { Gibbsite }\end{array}$ & $\begin{array}{l}\text { Bayerite } \\
\text { Sodium oxalate } \\
\text { Natrophospate } \\
\text { Gibbsite }\end{array}$ & $\begin{array}{l}\text { Sodium oxalate } \\
\text { Natrophospate }\end{array}$ & $\begin{array}{l}\text { Sodium oxalate } \\
\text { Natrophospate }\end{array}$ \\
\hline
\end{tabular}

Table 24. Solids in Waste Feed - Recycle Blends: Envelope B

\begin{tabular}{|c|c|c|c|c|c|}
\hline Simulant & $\begin{array}{l}\text { Solids in Waste } \\
\text { Feed }\end{array}$ & $\begin{array}{l}\text { Solids in Blends } \\
\text { with } 33 \% \text { UF1B }\end{array}$ & $\begin{array}{l}\text { Solids in } \\
\text { Blends with } \\
67 \% \text { UF1B }\end{array}$ & $\begin{array}{l}\text { Solids in } \\
\text { Blends with } \\
33 \% \text { MOGC }\end{array}$ & $\begin{array}{l}\text { Solids in } \\
\text { Blends with } \\
55 \% \text { MOGC }\end{array}$ \\
\hline $\begin{array}{l}3.5 \mathrm{wt} \% \\
\mathrm{AZ}-102\end{array}$ & $\begin{array}{l}\text { Corundum } \\
\text { Quartz } \\
\mathrm{FeO}(\mathrm{OH}) \\
\text { Sodium Aluminate } \\
\mathrm{Na}_{3} \mathrm{FSO}_{4} \\
\text { Sodium oxalate }\end{array}$ & $\begin{array}{l}\text { Corundum } \\
\text { Quartz } \\
\mathrm{FeO}(\mathrm{OH}) \\
\text { Sodium Aluminate } \\
\mathrm{Na}_{3} \mathrm{FSO}_{4} \\
\text { Sodium oxalate }\end{array}$ & $\begin{array}{l}\text { Corundum } \\
\text { Quartz } \\
\mathrm{FeO}(\mathrm{OH}) \\
\text { Sodium } \\
\text { Aluminate } \\
\mathrm{Na}_{3} \mathrm{FSO}_{4} \\
\text { Sodium carbonate } \\
\text { hydrate }\end{array}$ & $\begin{array}{l}\text { Corundum } \\
\text { Quartz } \\
\mathrm{FeO}(\mathrm{OH}) \\
\text { Sodium } \\
\text { Aluminate } \\
\mathrm{Na}_{3} \mathrm{FSO}_{4} \\
\text { Sodium oxalate }\end{array}$ & $\begin{array}{l}\text { Corundum } \\
\text { Quartz } \\
\mathrm{FeO}(\mathrm{OH}) \\
\text { Sodium } \\
\text { Aluminate } \\
\mathrm{Na}_{3} \mathrm{FSO}_{4} \\
\text { Sodium oxalate }\end{array}$ \\
\hline
\end{tabular}

Table 25. Solids in Waste Feed - Recycle Blends: Envelope C

\begin{tabular}{|c|c|c|c|c|c|}
\hline Simulant & $\begin{array}{l}\text { Solids in Waste } \\
\text { Feed }\end{array}$ & $\begin{array}{l}\text { Solids in Blends } \\
\text { with } 33 \% \text { UF3C }\end{array}$ & $\begin{array}{l}\text { Solids in } \\
\text { Blends with } \\
67 \% \text { UF3C }\end{array}$ & $\begin{array}{l}\text { Solids in } \\
\text { Blends with } \\
33 \% \text { MOGC }\end{array}$ & $\begin{array}{l}\text { Solids in } \\
\text { Blends with } \\
55 \% \text { MOGC }\end{array}$ \\
\hline AN-102 & $\begin{array}{l}\text { Sodium nitrate } \\
\mathrm{Na}_{3} \mathrm{FSO}_{4} \\
\text { Natrophosphate } \\
\text { Sodium carbonate } \\
\text { hydrate }\end{array}$ & Natrophosphate & Natrophosphate & $\begin{array}{l}\text { Sodium nitrate } \\
\text { Natrophosphate }\end{array}$ & $\begin{array}{l}\text { Sodium nitrate } \\
\text { Natrophosphate } \\
\text { Quartz }\end{array}$ \\
\hline AN-107 & $\begin{array}{l}\text { Sodium nitrate } \\
\mathrm{Na}_{2} \mathrm{Ca}\left(\mathrm{CO}_{3}\right)_{2} \\
5 \mathrm{H}_{2} \mathrm{O}\end{array}$ & $\begin{array}{l}\text { Sodium nitrate } \\
\mathbf{N a}_{5} \mathbf{A l}_{3} \mathbf{C S i}_{3} \mathbf{O}_{15} *\end{array}$ & $\begin{array}{l}\text { Sodium nitrate } \\
\mathrm{Na}_{2} \mathrm{Ca}\left(\mathrm{CO}_{3}\right)_{2} \cdot \\
5 \mathrm{H}_{2} \mathrm{O} \\
\text { Quartz }\end{array}$ & Sodium nitrate & $\begin{array}{l}\text { Sodium nitrate } \\
\mathrm{Na}_{2} \mathrm{Ca}\left(\mathrm{CO}_{3}\right)_{2} \cdot \\
5 \mathrm{H}_{2} \mathrm{O} \\
\text { Quartz }\end{array}$ \\
\hline
\end{tabular}

* Natrodavyne was also noted in Envelope C samples during treated feed testing. 


\subsection{Sr Solubility during Waste Feed Evaporation}

The amount of soluble strontium was measured in the Envelope $\mathrm{C}$ recycle samples before blending of the UF recycle, prior to evaporation, and after evaporation of the recycle. A slurry sample was submitted along with a filtered supernate sample to determine the amount of strontium in the slurry versus the amount of $\mathrm{Sr}$ in the supernate only. The measurement of soluble $\mathrm{Sr}$ before and after evaporation of the Envelope $\mathrm{C}$ recycles indicated that the evaporation process did not significantly increase the amount of soluble strontium present.

As shown in Table 21, the acid cleaning solution was the primary source of strontium in the recycle stream and that the strontium is primarily aqueous. Blending the acid cleaning solution with the $1^{\text {st }}$ wash and caustic rinse solution followed by adjustment of $\mathrm{pH}$ to 13 with $19 \mathrm{M}$ sodium hydroxide caused the strontium to precipitate as sodium strontium phosphate hydrate $\left(\mathrm{NaSrPO}_{4} \cdot 9 \mathrm{H}_{2} \mathrm{O}\right)$ leaving very little aqueous strontium in the evaporator feed.

The amount of aqueous strontium in the evaporator concentrate was increased by the same factor as the sodium content when evaporating only the UF recycle, as shown in Table 21. Evaporation of the UF recycle with $50 \%$ melter offgas condensate is shown in Table 22. When the condensate was added, a significant amount of the soluble strontium was precipitated. During concentration, only a portion of the strontium that precipitated during the condensate addition was redissolved. Therefore, the concentrate from the run with the melter offgas condensate contained less soluble strontium than the run with UF recycle only.

Table 26. Soluble Strontium in Envelope C UF Recycle

\begin{tabular}{|c|c|c|c|c|c|c|c|}
\hline Element & \multicolumn{2}{|c|}{$\begin{array}{c}\text { Acid Cleaning } \\
\text { Solution }\end{array}$} & 1st Wash & \multicolumn{2}{c|}{ UF3C Blend } & \multicolumn{2}{c|}{$\begin{array}{c}\text { UF3C } \\
\text { After Evaporation }\end{array}$} \\
\hline & Total & Supernate & Total & Total & Supernate & Total & Supernate \\
\hline & Molar & Molar & Molar & Molar & Molar & Molar & Molar \\
\hline $\mathrm{Na}$ & 0.033 & 0.019 & 3.87 & 2.16 & 2.13 & 5.83 & 6.04 \\
\hline $\mathrm{Sr}$ & $\mathbf{0 . 0 2 7}$ & $\mathbf{0 . 0 2 5}$ & $\mathbf{8 . 3 9 E - 0 5}$ & $\mathbf{0 . 0 0 6 2}$ & $\mathbf{3 . 1 5 E}-\mathbf{0 5}$ & $\mathbf{0 . 0 1 3}$ & $\mathbf{9 . 1 3 E - 0 5}$ \\
\hline
\end{tabular}

Table 27. Soluble Strontium UF Recycle with 50\% Melter Offgas Condensate

\begin{tabular}{|c|c|c|c|c|}
\hline Element & \multicolumn{2}{|c|}{$\begin{array}{c}\text { UF3C Blend with 50\% } \\
\text { SBS }\end{array}$} & $\begin{array}{c}\text { UF3C Blend with } 50 \% \\
\text { SBS After } \\
\text { Evaporation }\end{array}$ \\
\hline & Total & Supernate & Total & Supernate \\
\hline & Molar & Molar & Molar & Molar \\
\hline $\mathrm{Na}$ & 1.07 & 0.96 & 5.46 & 5.48 \\
\hline $\mathrm{Sr}$ & $\mathbf{0 . 0 0 3 2}$ & $\mathbf{1 . 6 E}-06$ & $\mathbf{0 . 0 1 1}$ & $\mathbf{3 . 4 E - 0 5}$ \\
\hline
\end{tabular}

The concentrated recycle was blended with simulated Envelope C waste feeds and precipitated using the process shown in Section 3.1.6 along with the simulated waste feeds diluted to $6 \mathrm{M} \mathrm{Na}$ with DI water. As shown in Table 23, the precipitation reaction led to similar amounts of soluble 
strontium in the runs with or without recycle additions. The values for soluble strontium in the waste feeds compare favorably with previous studies. ${ }^{9,10}$

Table 28. Soluble Sr in Precipitated Recycle/Waste Simulant Blends

\begin{tabular}{|l|c|c|}
\hline Blend Type & $\begin{array}{c}\text { Soluble Sr in } \\
\text { Previous } \\
\text { Studies }\end{array}$ & Soluble Sr \\
\cline { 2 - 3 } & Molar & Molar \\
\hline AN-102 only & $3.1 \mathrm{E}-04$ & $2.35 \mathrm{E}-04$ \\
\hline AN-102 w/ 33\% UF Recycle & n/a & $2.25 \mathrm{E}-04$ \\
\hline AN-102 w/ 67\% UF Recycle & n/a & $2.41 \mathrm{E}-04$ \\
\hline AN-102 w/ 33\% MOGC & n/a & $2.68 \mathrm{E}-04$ \\
\hline AN-102 w/ 55\% MOGC & n/a & $2.33 \mathrm{E}-04$ \\
\hline AN-107 only & $1.31 \mathrm{E}-03$ & $1.67 \mathrm{E}-03$ \\
\hline AN-107 w/ 33\% UF Recycle & n/a & $1.47 \mathrm{E}-03$ \\
\hline AN-107 w/ 67\% UF Recycle & n/a & $1.55 \mathrm{E}-03$ \\
\hline AN-107 w/ 33\% MOGC & n/a & $1.20 \mathrm{E}-03$ \\
\hline AN-107 w/ 55\% MOGC & n/a & $1.45 \mathrm{E}-03$ \\
\hline
\end{tabular}

\subsection{Sodium Alumino-silicate Formation}

Sodium alumino-silicate (NAS) formation has been noted in SRS waste evaporators that has led to extensive fouling of the evaporator vessel. The aluminum and silica concentrations to be processed by the WTP are higher than the levels processed at SRS, therefore the potential to form NAS precipitants was examined. Samples of the simulated evaporator feeds, evaporator concentrates, and blends of waste feed simulants with recycle were filtered and the solids were sent for characterization by XRD analysis. Out of a total of approximately 140 samples sent for analysis, 21 samples were identified as having sodium alumino-silicate (NAS) present.

Sodium alumino-silicates were not noted in any evaporator feed or concentrate sample, except as one Envelope A sample discussed below. Three Envelope C samples were re-submitted for XRD analysis after settling for several months to eliminate kinetics concerns in the identification of NAS, no NAS solids were noted in the XRD for these samples.

One sample of concentrated Envelope A recycle and one sample of Envelope C blended waste feed and recycle concentrate were identified as having NAS present. The peak for the Envelope A recycle was very questionable and identification of NAS in this sample is uncertain. The concentrated recycle was added to each of the 12 Envelope A waste feed simulants, but only $1 / 3$

${ }^{9}$ J.R. Zamecnik, et al, AN-102 Simulant Sr/TRU Precipitation and Ultrafiltration (U), WSRCTR-2003-00056, Rev 0, February 10, 2003.

${ }^{10}$ R.T. Hallen, et al, Demonstration of Entrained Solids and Sr/TRU Removal Processes with Archived AN-107 Waste. PNWD-3033, BNFL-RPT-026 Rev 0, July 2000. 
of the blended samples contained NAS, as discussed below. Based on the results of the blended samples, it was concluded that NAS did not form in the Envelope A recycle streams before or during evaporation in amounts that are detected by the XRD analysis.

One Envelope $\mathrm{C}$ sample of the concentrated recycle blended with waste feed contained natrodavyne $\left(\mathrm{Na}_{3} \mathrm{Al}_{3} \mathrm{Si}_{3} \mathrm{O}_{12}-\mathrm{Na}_{2} \mathrm{CO}_{3}\right)$. This compound was also identified in the Treated Feed Evaporation study during Envelope $\mathrm{C}$ tests. Natrodavyne is a form of cancrinite with sodium carbonate present inside the NAS crystalline structure.

Four of the Envelope A simulant (SM-02, SM-03, SM-06, and SM08) matrix points contained the minimum aluminum and hydroxide concentrations. Four different blends were conducted with each waste simulant, therefore sixteen blends utilizing the four low $\mathrm{Al}$ and low $\mathrm{OH}^{-}$were tested. All sixteen of these blends contained Zeolite A while none of the remaining 32 Envelope A blend samples contained Zeolite A or other forms of NAS, as shown in Figure 12. The same four matrix points indicated the presence of Zeolite A during the treated feed evaporation tests ${ }^{11}$ when made up at $5 \mathrm{M}$ sodium, indicating that dilution of these samples from $7 \mathrm{M}$ to $5 \mathrm{M}$ with DI water was sufficient to cause NAS formation. NAS formation was not noted in the 7M Envelope A matrix samples.

A comparison was made between the results of these tests and the results from thermodynamic modeling of SRS evaporators. The same trends were noted with aluminum and hydroxide concentrations as high aluminum and/or high hydroxide concentration was found to suppress NAS formation. ${ }^{12}$ The operating region where NAS is expected to form in SRS evaporators has been determined. The data indicates that determination of a similar region for the WTP process may be feasible, but additional data and analysis is required.

A total of 13 simulants representing the blended waste feed and recycle concentrate were tested for validation of the OLI model of the waste feed evaporator and UF systems. Three of these samples contained Zeolite A. As shown by Figure 12, the samples showing NAS for the OLI validation did not indicate the same pattern with aluminum and hydroxide concentrations as noted for the blended feeds from the evaporation studies. The processing history of a sample could be impacting the type of solids noted in the samples, causing the difference in results between the OLI validation samples and the evaporation test samples. The evaporation test samples discussed above were the result of blending and processing numerous individual streams through the WTP flowsheet to produce the final blended stream that will be fed to the UF process. The OLI validation simulants were compositions determined by the OLI model for the UF process feed and were madeup from raw chemicals in one step. The formation of gibbsite and bayerite in the evaporator test samples prior to blending with the waste feed may have prevented NAS formation in compositions similar to the OLI validation simulants that formed NAS.

${ }^{11}$ J.E. Josephs, Treated Feed Evaporation: Physical Properties and Solubility Determinations (U), WSRC-TR-2003-00119, March 2003.

${ }^{12}$ C. M Jantzen, et al, Thermodynamic Modeling of the SRS Evaporators: Part IV. Incorporation of High Caustic Aluminosilicaate Solubility Data (U), WSRC-TR-2002-00330, March 15, 2003. 
The waste feed evaporation results indicated significantly less frequent NAS formation than the treated feed evaporation study. Approximately one-half of the Envelope A and one-fourth of the C samples from the treated feed study indicated the presence of NAS formation. Gibbsite and bayerite were present more frequently in the waste feed samples indicating that these compounds were more favored in the waste feed evaporator than in the treated feed evaporator, possibly minimizing the formation of NAS.

The techniques used to detect NAS solids in the samples have some limitations. The formation of small amounts of crystaline solids ( $<1 \%$ of solids) would not be detected by the XRD method and the detection limit is higher for some species. In addition, the NAS gel precursor to Zeolite $\mathrm{A}$ is amorphous and would not be detected. Although the samples were not analyzed until at least one week after make-up, kinetics of NAS formation could also have prevented detection in solutions that would have formed NAS solids over longer time periods. However, a recheck of the solids content in the Envelope A waste feeds indicated that little additional solids formation had occurred in most samples and the resubmittal of the Envelope $\mathrm{C}$ samples indicate that kinetics did not impact the NAS determinations.

The experimental results indicate that significant NAS formation in the waste feed evaporator is unlikely, but that other aluminate species (gibbsite and bayerite) will be present and could cause fouling in the waste feed evaporator. The lab-scale apparatus utilized for this testing did not allow fouling of the evaporator to be studied. Pilot scale studies of the waste feed and treated feed evaporation process should be monitored closely for fouling. Although NAS formation in the evaporator is not likely, formation in downstream processing was noted, therefore the impact of NAS solids on the ultrafiltration process should be studied.

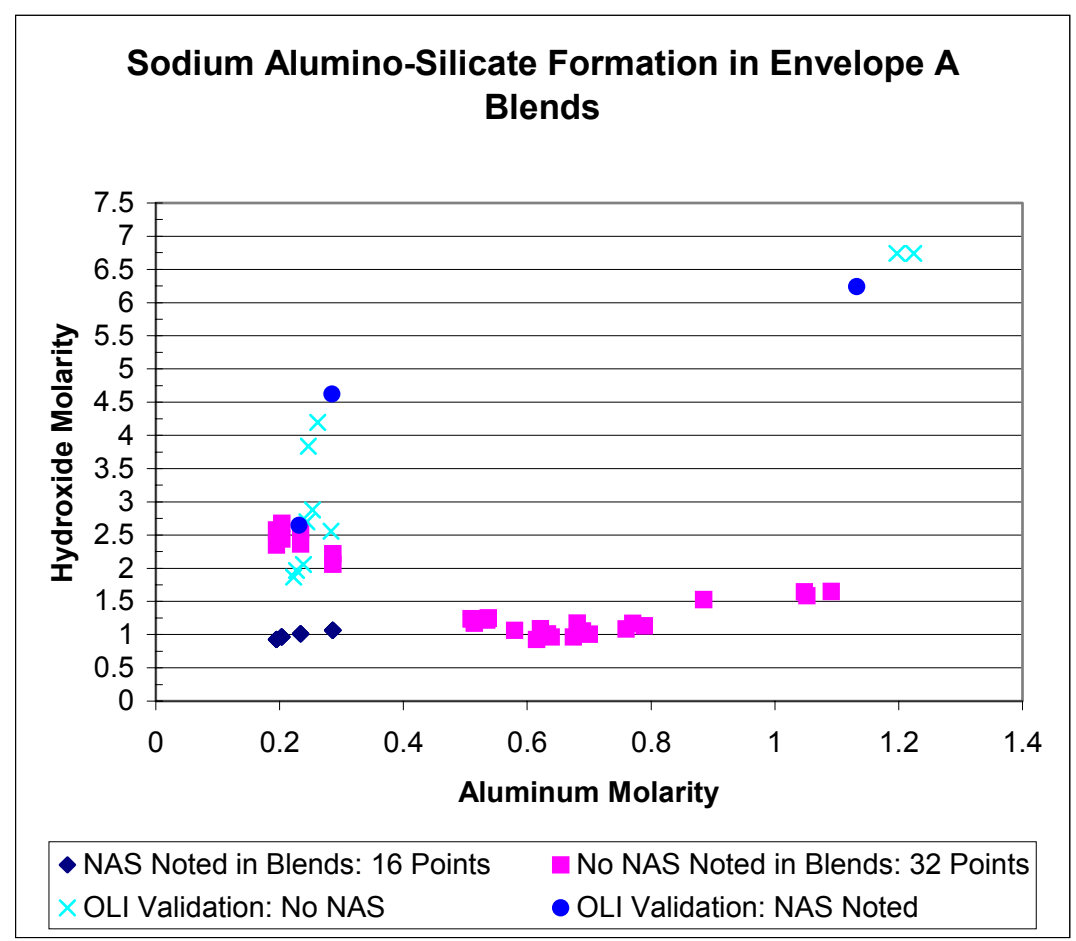

Figure 12. NAS Formation in Envelope A Waste / Recycle Blends 


\subsection{Physical Property Testing and Instrumentation}

\subsubsection{Specific Gravity}

Density as a function of temperature and concentration was measured by an Anton Paar DMA4500 Density Analyzer, as shown in Figure 13, with density and temperature accuracy $=10^{-}$ ${ }^{3} \mathrm{~g} / \mathrm{ml}$ and $0.03^{\circ} \mathrm{C}$, respectively. Deionized water and $40 \%$ sodium nitrate standard solutions were used in calibration checks on the instrument. A $1.5 \mathrm{ml}$ portion of a thoroughly mixed sample was injected into an inlet port using a $3 \mathrm{ml}$ syringe which remained at the inlet. The instrument heated or cooled the sample to the desired temperature prior to the density measurement. Density was measured by measuring the dampening of a vibrating U-tube filled with sample with automatic compensation for viscosity impacts. The sample was run twice at each temperature and the average value reported.
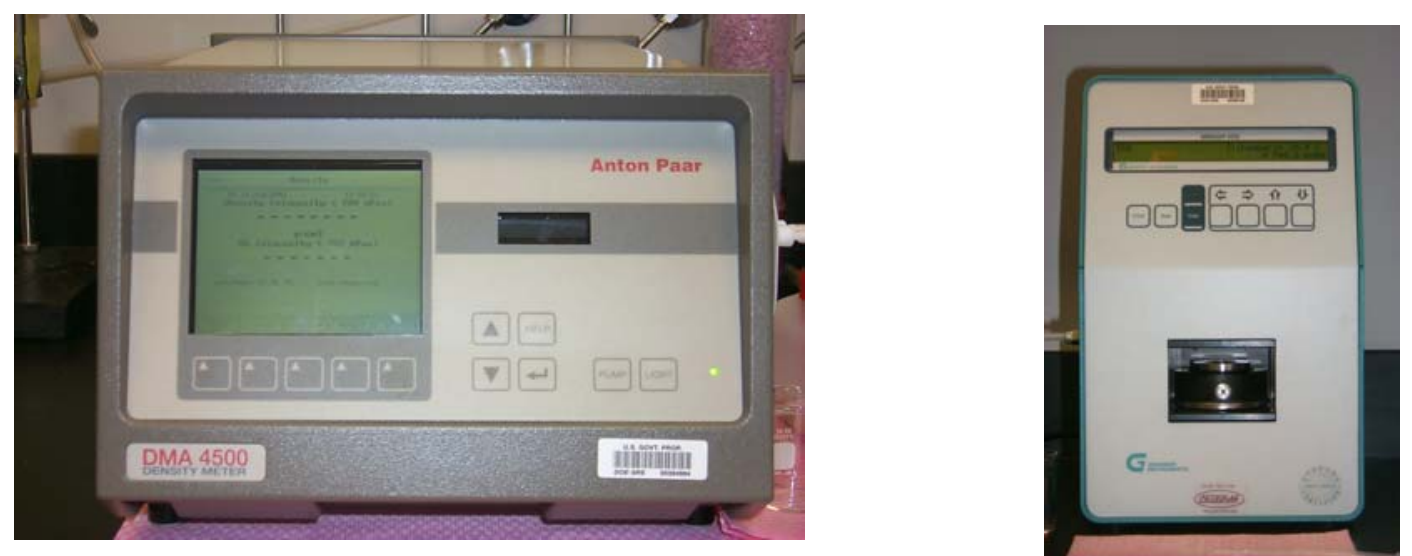

Figure 13. Anton Paar DMA-4500 and Grabner MiniVap VOC Instruments

The density of the all samples was most strongly influenced by the bulk concentration of dissolved salts with a smaller impact from temperature, as shown in Figure C-1 through C-9 of Appendix C. The impact variations in minor salts was small as indicated by the regressions indicating good correlations using only sodium for the impact of sample concentration. The effect of temperature on the sample densities was only slightly greater than the impact of temperature on water density. Conversion of the data from density to specific gravity reduced the impact of temperature sufficiently to allow regressions to be performed that utilized sodium concentration only.

The regressions were performed without regard for the amount of MOGC blended with UF recycle for the recycle only correlations and without regard for the type or amount of recycle for the blend regressions. Correlations were also developed for the blended streams for each Envelope. These correlations were derived for the supernate as well as the total slurry, as shown below.

The curve fits for Envelope A and B were performed as a linear function of sodium concentration. The curve fits for these envelopes were not improved by increasing the order of 
the correlation and fixing the intercepts at 1.00 did not significantly impact the quality of the curve fits. For Envelope $\mathrm{C}$, the data indicated significantly more curvature in the blend samples and curve fits were dramatically improved by using a second order curve fit.

Correlations were developed for the specific gravity of Envelope A and B as follows:

Specific gravity $=A * \mathrm{M}_{\mathrm{Na}}+1.00$

Where: $\quad \mathrm{M}_{\mathrm{Na}}=$ the sodium molarity of the slurry

A $=$ the slope from the Table 24

Table 29. Parameters for Envelope A and B Specific Gravity Correlations

\begin{tabular}{|l|c|c|c|}
\hline Correlation & Valid Range & $\mathrm{A}$ & $\mathrm{R}^{2}$ \\
\hline Units & Molar Na & $1 /($ Molar Na) & N/A \\
\hline Envelope A Recycle & 0.0 to 5.5 & 0.0548 & 0.98 \\
\hline Envelope B Recycle & 0.0 to 5.0 & 0.0501 & 0.97 \\
\hline & & & \\
\hline Envelope A Blends & 0.0 to 7.5 & 0.0482 & 0.92 \\
\hline Envelope A Blend Supernate & 4.5 to 7.5 & 0.0458 & 0.82 \\
\hline & & & \\
\hline Envelope B Blends & 0.0 to 5.0 & 0.0597 & 0.91 \\
\hline Envelope B Blend Supernate & 0.0 to 5.0 & 0.0524 & 0.99 \\
\hline
\end{tabular}

Correlations were developed for the specific gravity of Envelope $\mathrm{C}$ as follows:

Specific gravity $=A *\left(\mathrm{M}_{\mathrm{Na}}\right)^{2}+\mathrm{B} * \mathrm{M}_{\mathrm{Na}}+1.00$

Where: $\quad \mathrm{M}_{\mathrm{Na}}=$ the sodium molarity of the slurry

$\mathrm{A}=$ the value from the Table 25

$\mathrm{B}=$ the value from the Table 25

Table 30. Parameters for Envelope C Specific Gravity Correlations

\begin{tabular}{|l|c|c|c|c|}
\hline Correlation & Valid Range & $\mathrm{A}$ & $\mathrm{B}$ & $\mathrm{R}^{2}$ \\
\hline Units & Molar Na & $1 /($ Molar Na) & $1 /(\text { Molar Na })^{2}$ & $\mathrm{~N} / \mathrm{A}$ \\
\hline Envelope C Recycle & 0.0 to 6.0 & -0.0017 & 0.0566 & 1.00 \\
\hline Envelope C Blends & 0.0 to 10.0 & -0.0016 & 0.0597 & 0.97 \\
\hline Envelope C Blend Supernate & 4.0 to 6.5 & -0.0032 & 0.0676 & 0.99 \\
\hline
\end{tabular}




\subsubsection{Vapor Pressure}

A MiniVap VOC from Grabner Instruments, as shown in Figure 13, was used to measure vapor pressure of the mixtures as a function of temperature with an accuracy of $\pm 10 \%$ on pressure and $\pm 0.1^{\circ} \mathrm{C}$ on temperature. The instrument was preset to read vapor pressures of the samples at 15 , $25,35,45,55$, and $65^{\circ} \mathrm{C}$ using approximately $1 \mathrm{ml}$ of sample. The instrument evacuated the sample chamber above the process sample, then measured chamber pressure and temperature as the sample was heated or cooled to the desired temperature(s). De-ionized water was used to check the instrument prior to measurements.

The results indicated that the vapor pressure was primarily dependent on temperature with a secondary impact from bulk salt concentration as represented by sodium concentration. A correlation was developed that included all waste envelopes as shown below and in Figure C-10 of Appendix C.

Vapor Pressure Correlation: Valid over 15 to 65 Celsius and 0 to $7.5 \mathrm{M} \mathrm{Na}-\mathrm{R}^{2}=0.995$

$$
\begin{gathered}
\text { Vapor Pressure }(\mathrm{mm} \mathrm{Hg})=19.3235+2.398815 \mathrm{M}_{\mathrm{Na}}-1.38003 \mathrm{~T}-0.02894\left(\mathrm{M}_{\mathrm{Na}}\right)^{2}+0.059138 \mathrm{~T}^{2} \\
-0.12527 \mathrm{M}_{\mathrm{Na}} * \mathrm{~T}
\end{gathered}
$$

Where $\mathrm{M}_{\mathrm{Na}}=$ Sodium molarity and $\mathrm{T}=$ Temperature (Celsius)

This equation was utilized to solve for the evaporator operating temperature as a function of sodium concentration, as shown in Figure 14. The minimum operating temperature of the evaporator was determined to be $42{ }^{\circ} \mathrm{C}$ while the maximum temperature at $5 \mathrm{M}$ was determined to be $49^{\circ} \mathrm{C}$. As shown, the operating pressure of the evaporator can change the operating temperature significantly compared to the changes in operating temperature due to sodium concentration.

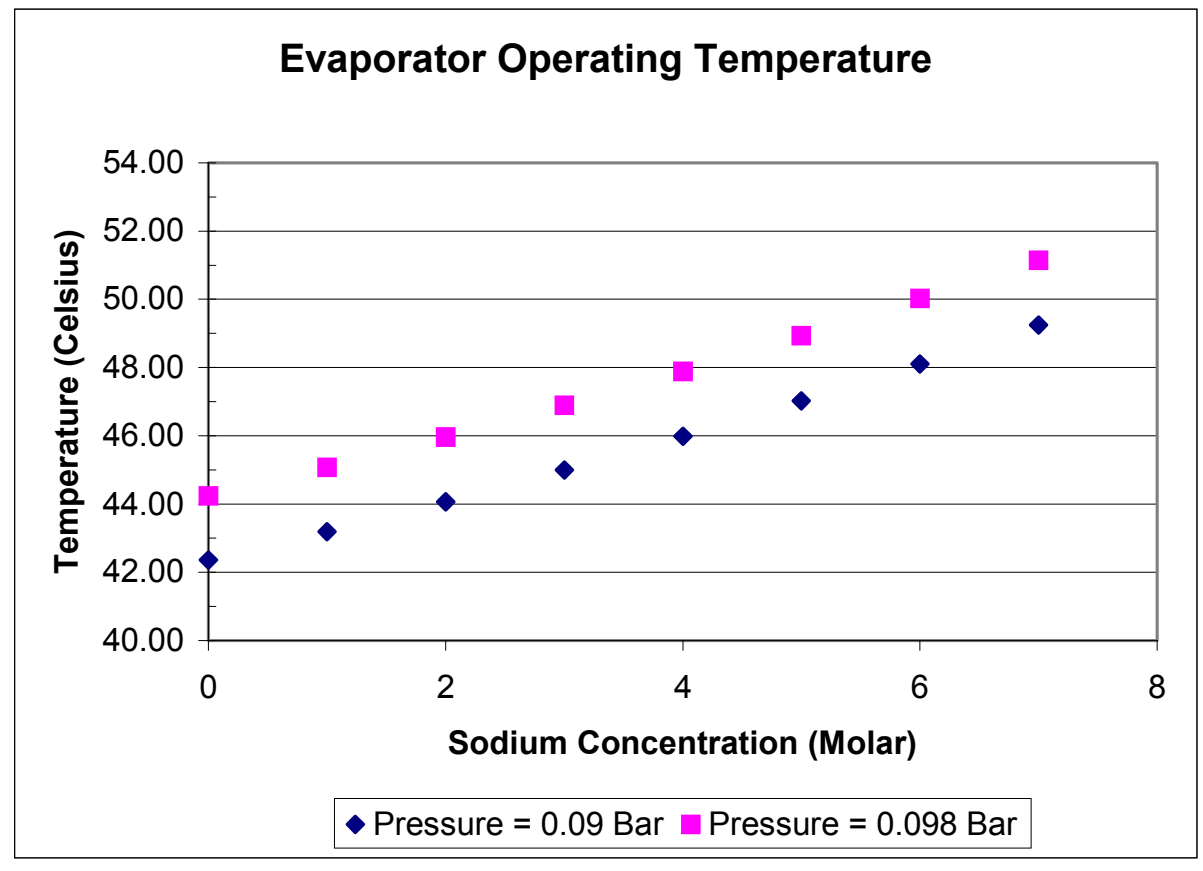


WSRC-TR-2003-00212, Rev. 0

SRT-RPP-2003-00094, Rev. 0

\section{Figure 14. Expected Operating Temperature of Waste Feed Evaporator}

The insensitivity of vapor pressure to variations in minor components was indicated by the results of the AZ-102 tests. The vapor pressure of the evaporator concentrate is shown in Figure 15 and indicates that the vapor pressure was not impacted by the addition of recycle to the waste feed.

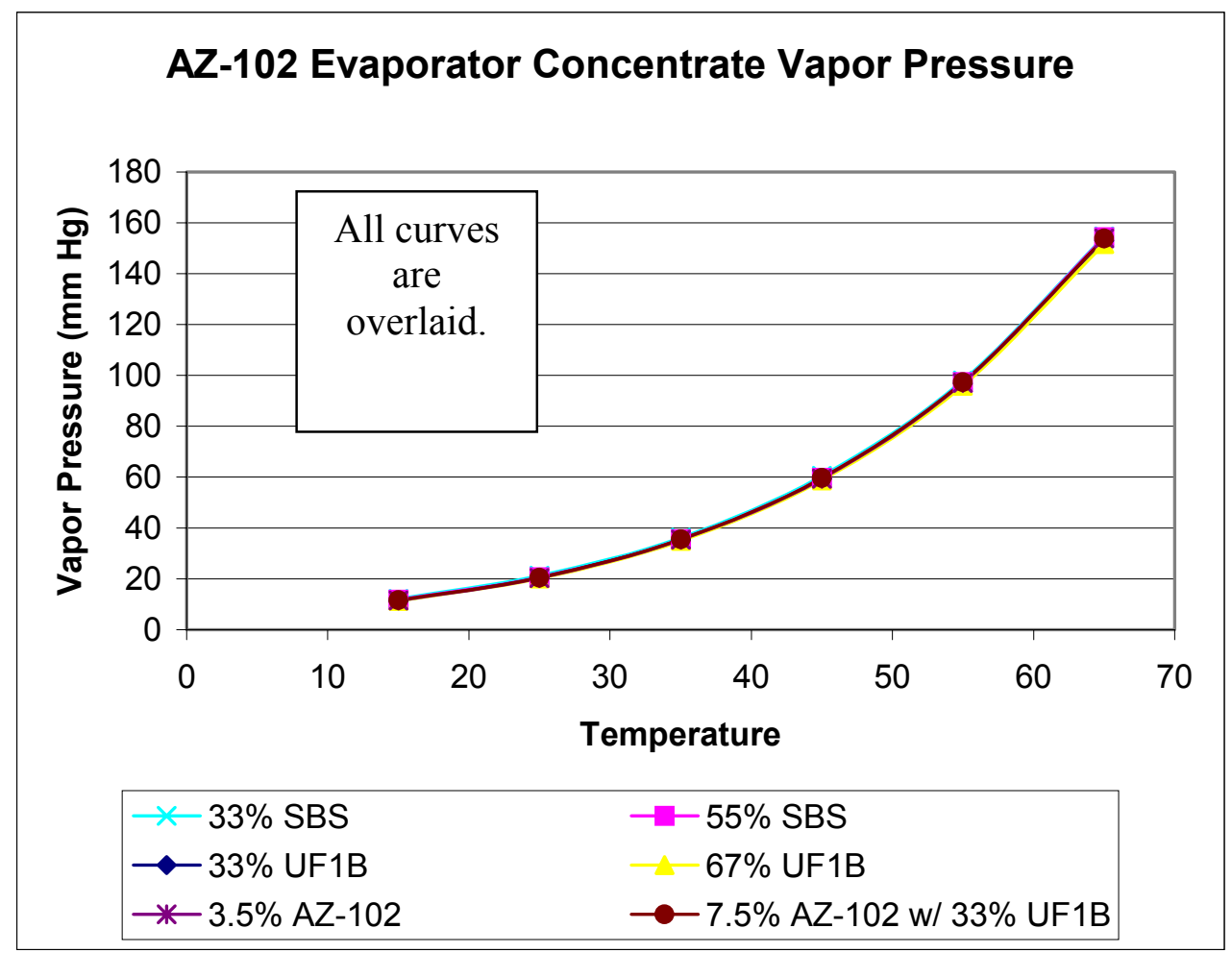

Figure 15. Vapor Pressure of AZ-102 Evaporator Concentrates

\subsubsection{Viscosity}

The rheological properties (viscosity and flow curves) were measured using Haake RS150 and Haake RS600 rheometers with an accuracy of $\pm 10 \%$. A majority of these solutions were suspected to be Newtonian in nature and in these cases, the viscosity of these solutions was measured without performing flow curve measurements. The measurement required that the sample come to thermal equilibrium and then be ramped to a high shear rate for 40 seconds, where both the shear stress and shear rate are measured. The viscosity is then averaged, using the shear stress and shear rate between 5 and 35 seconds. This analysis is conducted in a fraction of time compared to a complete flow curve.

The viscosity measurements were predominately performed using a $60 \mathrm{~mm}, 0.5$ degree cone/plate geometry at various temperatures. A double concentric bob/cup geometry (DG41) was also used, but problems were noted at elevated temperatures. This method is recommended for all Newtonian fluids and it is recommended that the rheological section of the RPP-WTP technology development procedure Smith, Gary and Prindiville, Kerry, "Guidelines for Performing Chemical, Physical and Rheological Properties Measurements", 24590-WTP-GPG- 
WSRC-TR-2003-00212, Rev. 0

SRT-RPP-2003-00094, Rev. 0

RTD-001, Rev. 0, 5/20/02 be revised to include this measurement technique. This methodology was discussed with key WTP personnel (R. L. Longwell, Evaporation Lead and G. Smith, Simulant Validation Lead) prior to performing these measurements.

Flow curves were measured using 60mm 0.5 degree cone/plate, DG41, and concentric bob/cup (Z41) geometries. The rheometers were functionally checked using NIST traceable oil standards and DI water. All measuring heads were inspected for damaged prior to use.

The recycle streams for each waste envelope for the supernate viscosity at 25 Celsius, were curve fitted using an exponential function as shown below. All curve fits were forced to have an intercept value of water ( $0.89 \mathrm{mPa} s e c$ at 25 Celsius $)$, given a sodium molarity of zero. The supernate viscosity of the blended streams was also measured and fitted with an exponential function that included all samples from a given envelope (recycle only, waste feed only, and blends). The coefficients to the fitted function are shown in Table 26 and in Appendix $\mathrm{C}$, Figures C-11 through C-16 for viscosities at 25 Celsius, with the intercepts forced having the value of water $(0.89 \mathrm{mPa} \cdot \mathrm{sec}$ at $25 \mathrm{C})$ for a sodium molarity of zero.

$$
\mu_{25^{\circ} \mathrm{C}}=0.89 \cdot e^{A \cdot M_{N a}}
$$

Where: $\quad \mu_{25^{\circ} \mathrm{C}}=\quad$ viscosity (mPa $\quad$ sec) at 25 Celsius

$\mathrm{M}_{\mathrm{Na}}=$ Sodium molarity

A $=$ Value from the Table 26 (1/Molarity)

Table 31. Parameters for Viscosity Correlations as a Function of Sodium Concentration

$$
\begin{gathered}
\text { Correlation } \\
\text { Units }
\end{gathered}
$$

Envelope A Recycle Supernate

Envelope B Recycle Supernate

Envelope C Recycle Supernate

\section{Valid Range}

Molar Na

0.0 to 5.5

0.0 to 5.0

0.0 to 6.0

0.0 to 7.5
0.0 to 5.0
0.0 to 6.5
A

1/Molarity

0.2557

0.2346

0.1690

0.2258

0.2453

0.1856
$\mathrm{R}^{2}$

$\mathrm{N} / \mathrm{A}$

0.92

0.96

0.97

0.85

0.97

0.91

Selected samples were characterized at higher temperatures to determine the impact of temperature on viscosity. The data was fitted to an exponential function as shown below for Envelopes $\mathrm{A}$ and $\mathrm{B}$ at $5 \mathrm{M}$ sodium concentration and for Envelope $\mathrm{C}$ precipitated supernate at $6 \mathrm{M}$ sodium concentration, and are shown in Figures $\mathrm{C}-17$ through $\mathrm{C}-19$ of Appendix $\mathrm{C}$.

$$
\mu(T)=B \cdot e^{A_{1} \cdot T}
$$

Where: $\quad \mu(\mathrm{T})=\quad$ viscosity at temperature $\mathrm{T}(\mathrm{mPa} \sec )$

$$
\mathrm{T}=\text { Temperature (Celsius) }
$$

$\mathrm{A}_{1}=$ Value from the Table 27 (1/Celsius)

$\mathrm{B}=$ Intercept from Table $27(\mathrm{mPasec})$ 
WSRC-TR-2003-00212, Rev. 0

SRT-RPP-2003-00094, Rev. 0

\section{Table 32. Parameters for Viscosity Correlations as a Function of Temperature}

Correlation

Units

Envelope $\mathrm{A}$ at $5 \mathrm{M} \mathrm{Na}$

Envelope $\mathrm{B}$ at $5 \mathrm{M} \mathrm{Na}$

Envelope $\mathrm{C}$ at $6 \mathrm{M} \mathrm{Na}$
Temperature Range

Celsius

20 to 70

20 to 70

20 to 70
$\mathrm{A}_{1}$

(1/Celsius)

$-0.0205$

$-0.0182$

$-0.0172$

\section{B}

$\mathrm{mPa} \cdot \mathrm{sec}$

$\mathrm{R}^{2}$

4.8617

4.3332

3.3952
$\mathrm{N} / \mathrm{A}$

0.80

0.99

0.92

\subsubsection{Heat Capacity}

Heat capacity (units of $\mathrm{J} / \mathrm{g} \cdot \mathrm{K}$ ) was obtained using a Perkin Elmer DSC 7. The Perkin DSC was calibrated using an $\mathrm{Al}_{2} \mathrm{O}_{3}$ (aluminum oxide-sapphire) standard from 30 to $85^{\circ} \mathrm{C}$ and water. The instrument is a Differential Scanning Calorimeter and determined heat capacity by monitoring the temperature and power supplied to the sample during the test.

The heat capacity was found to be a function of sodium concentration for the UF recycles. The dependence of heat capacity on temperature was found to be within the experimental error $(+/-$ $3 \%$ of reading) and was not included in the correlations. The heat capacity was measured over a temperature range of $40^{\circ} \mathrm{C}$ to $85^{\circ} \mathrm{C}$. Curve fits were developed as shown below and in Appendix C, Figures C-20 through C-25. for the recycle streams for each envelope. All intercepts were forced to the value for water $(1.00 \mathrm{cal} / \mathrm{g}-\mathrm{C})$.

Heat capacity of the blended samples was also measured. Correlations were developed for each envelope that combined the results from the waste feed without recycle, the recycle only, and blends of the waste feed with recycle. All intercepts were forced to the value for water (1.00 $\mathrm{cal} / \mathrm{g}-\mathrm{C})$.

Correlations for heat capacity followed the form:

$$
\text { Heat Capacity }(\text { calories/gram-Celsius })=A *\left(\mathrm{M}_{\mathrm{Na}}\right)^{2}+\mathrm{B} * \mathrm{M}_{\mathrm{Na}}+1.00
$$

Where:

$$
\begin{array}{lll}
\mathrm{M}_{\mathrm{Na}} & = & \text { Sodium molarity } \\
\mathrm{A} & = & \text { Value from Table 28 } \\
\mathrm{B} & = & \text { Value from Table 28 }
\end{array}
$$

Table 28. Parameters for Heat Capacity Correlations

\begin{tabular}{|l|c|c|c|c|}
\hline Correlation & Valid Range & $\mathrm{A}$ & $\mathrm{B}$ & $\mathrm{R}^{2}$ \\
\hline Units & Molar Na & $1 /($ Molar Na) & $1 /(\mathrm{Molar} \mathrm{Na})^{2}$ & $\mathrm{~N} / \mathrm{A}$ \\
\hline Envelope A Recycle & 0.0 to 5.5 & 0.0067 & -0.0782 & 0.92 \\
\hline Envelope B Recycle & 0.0 to 5.0 & 0.0074 & -0.0745 & 0.98 \\
\hline Envelope C Recycle & 0.0 to 6.0 & 0.0060 & -0.0730 & 0.99 \\
\hline & & & & \\
\hline Envelope A Blends & 0.0 to 7.5 & 0.0057 & -0.0706 & 0.84 \\
\hline Envelope B Blends & 0.0 to 5.5 & 0.0072 & -0.0759 & 0.96 \\
\hline Envelope C Blends & 0.0 to 6.5 & 0.0051 & -0.0698 & 0.99 \\
\hline
\end{tabular}




\subsubsection{Thermal Conductivity}

Thermal conductivity (units of $\mathrm{W} / \mathrm{m} \cdot{ }^{\circ} \mathrm{C}$ ) was obtained using a Perkin Elmer DSC 7. The Differential Scanning Calorimeter was calibrated using an $\mathrm{Al}_{2} \mathrm{O}_{3}$ (aluminum oxide-sapphire) standard from 30 to $85^{\circ} \mathrm{C}$ and water. Thermal conductivity was obtained by calculations performed in the data to determine the resistance of the sample to changes in temperature. The ratio of the resistance of the sample to the resistance of water is equal to the ratio of the thermal conductivity of the sample to the thermal conductivity of water.

A significant amount of scatter existed in the thermal conductivity data, as shown in Figures C26 throught $\mathrm{C}-28$ of Appendix C. The scatter indicated that the impact of sodium concentration on thermal conductivity was less than the error in the measurements. The scatter was nominally centered around the thermal conductivity of water $(0.58 \mathrm{~W} / \mathrm{m}-\mathrm{C})$, indicating that the thermal conductivity of the process slurries can be approximated using the values for water as long as an appropriate safety factor is utilized. Due to the scatter, correlations were not developed for thermal conductivity.

\subsubsection{Solids Content}

The solids content of samples was measured with a Mettler-Toledo HR73P Halogen Moisture Analyzer. Process samples were placed in the analyzer and heated to 120 degrees Celsius to remove moisture without destroying fragile components present in the sample. For determination of total, soluble, and insoluble solids content, two measurements were taken for each sample: the amount of solids in the sample and the amount of solids in the sample supernate. The supernate was prepared utilizing pressure filtration of a portion of the original sample. Insoluble solids content was then calculated from the difference between the total solids content and the supernate solids content. Results were reported in weight percent.

Measurement errors in the amounts of total solids and soluble solids can lead to significant uncertainty in the insoluble solids value when the amount of insoluble solids are small when compared to the amount of total solids due to subtracting two large numbers to obtain a small number. Two samples were run for each sample and averaged to minimize measurement error.

\subsection{7 pH Measurement}

Initial attempts to measure $\mathrm{pH}$ of UF recycles with standard probes resulted in unsatisfactory results due to the high salt content and the high $\mathrm{pH}$ range of the solutions. An ion-selective (ISFET) instrument was utilized from IQ Scientific Instruments with automatic temperature compensation along with narrow range $\mathrm{pH}$ paper to obtain accurate $\mathrm{pH}$ measurements. Results from the $\mathrm{pH}$ probe and $\mathrm{pH}$ paper indicated good agreement. 


\subsection{Conclusions}

Caustic adjustment of the UF recycle stream was required to prevent gel formation for the solutions tested. Actual amounts of caustic adjustment required will vary depending on the composition and volume ratios of the UF recycle.

The concentration of recycles in the waste feed evaporator as required to blend with waste feed streams to provide a feed to the ultrafiltration process with a supernate specific gravity of 1.22 is feasible. No problems (such as severe foaming) were noted during the lab-scale testing that would preclude operation of the evaporator.

The physical properties of the recycles and waste feed blends fit well to correlations based on sodium concentration and temperature.

Evaporation of streams containing high levels of insoluble solids may lead to "bumping" or other undesirable behavior in the evaporator at insoluble solids greater than $7 \mathrm{wt} \%$.

Sodium alumino-silicate solids were not noted in the evaporator feed or concentrate, but NAS did form in the blends of concentrated recycle and waste feeds.

Strontium was found to precipitate during neutralization of the acid cleaning solution and remain precipitated during evaporation.

Mercury was found to be significantly soluble in Envelope A simulants and the solubility of mercury increased during evaporation. No mercury was detected in the offgas system after evaporation using Envelope A simulants. Mercury was significantly less soluble in a simulant of AZ-102.

Filtration of the Envelope A waste simulants was affected by the addition of recycle to the process, but the impact was primarily due to an increase in the amount of insoluble solids in the blended stream compared to the waste feed.

\subsection{Future Work}

If scaling or buildup of solids occurs in the WTP pilot evaporator, bench scale cleaning and scaling studies should be conducted to determine the most appropriate cleaning method, disposal route, and downstream effects of the chosen cleaning solution.

If AZ-102 or other waste feeds with high insoluble solids content are to be evaporated in the Waste Feed Evaporator, pilot scale testing should be conducted to determine the impact of high solids loading on the evaporator. This testing should contain bench-scale tests to determine the impact of high insoluble solids concentration on viscosity.

Solids (e.g. Lithium aluminum carbonate hydroxide hydrate) formed in the recycle solutions that are not currently in the OLI Public database should be added and modeling studies conducted to 
WSRC-TR-2003-00212, Rev. 0

SRT-RPP-2003-00094, Rev. 0

determine the total quantity of these solids expected to precipitate in the Waste Feed Evaporator system.

The impact of NAS solids on the Ultrafiltration Process should be evaluated. The blends of concentrated recycle and waste feed represent the feed stream to the UF process. The formation of NAS in these streams was noted during the testing and could occur during WTP processing. Integrated pilot testing will be conducted to determine the impact of recycles on all unit operations of the WTP, but a limited number of compositions will be tested. If NAS formation is not noted during this testing, separate tests should be conducted to determine the impact of NAS.

Bench scale and/or pilot scale tests should be conducted prior to evaporation of recycle streams significantly beyond a supernate specific gravity of 1.22 to determine the maximum volume reduction factor allowable for the recycle streams. In addition, processing strategies which separate the individual UF recycle streams or significantly changes the compositions or volumes of the individual UF recycle streams should be evaluated with bench scale testing prior to implementation.

The blending of UF recycle streams will result in gel formation if the $\mathrm{pH}$ of the final blend is not sufficient to prevent aluminum species from forming gels. Additional work is required to refine the amount of caustic adjustment required to mitigate gel formation as a function of the amount and composition of the individual recycle streams to allow caustic additions to be minimized. Recycle mixing studies ${ }^{13}$ contained $\mathrm{NaOH}$ in the experimental test matrix and the resulting matrix did not evaluate streams below $\mathrm{pH} 14$ containing the UF $1^{\text {st }}$ and $2^{\text {nd }}$ wash recycles. The tests should also evaluate correction of the $\mathrm{pH}$ prediction in OLI or a suitable prediction method should be developed.

${ }^{13}$ Barnes, Mark j., et al, Recycle Stream Blending for High and Low Level Waste (DRAFT), WSRC-TR-2003-00156, April 30, 2003. 


\section{Appendix A. Composition Data}

Table A- 1. Target Compositions of Envelope A and B UF Recycle Streams

\begin{tabular}{|l|c|c|c|c|c|}
\hline $\begin{array}{l}\text { Molar } \\
\text { Concentrations }\end{array}$ & \multicolumn{2}{|c|}{ 1st Wash } & Leach & $\begin{array}{c}\text { 2nd } \\
\text { Wash }\end{array}$ & $\begin{array}{c}\text { Acid } \\
\text { Cleaning } \\
\text { Solution }\end{array}$ \\
\hline Element & Env. A & Env. B & & & \\
\hline Acetate & 0.000 & 0.012 & 0.000 & 0.000 & 0.000 \\
\hline Aluminum & 0.271 & 0.030 & 0.385 & 0.182 & 0.040 \\
\hline Boron & 0.000 & 0.000 & 0.002 & 0.000 & 0.000 \\
\hline Cadmium & 0.000 & 0.000 & 0.000 & 0.000 & 0.003 \\
\hline Carbonate & 0.209 & 0.542 & 0.075 & 0.029 & 0.000 \\
\hline Chloride & 0.060 & 0.000 & 0.025 & 0.010 & 0.000 \\
\hline Chromium & 0.000 & 0.016 & 0.000 & 0.000 & 0.000 \\
\hline Citrate & 0.000 & 0.024 & 0.000 & 0.000 & 0.000 \\
\hline Fluoride & 0.068 & 0.057 & 0.000 & 0.000 & 0.000 \\
\hline Formate & 0.000 & 0.108 & 0.000 & 0.000 & 0.000 \\
\hline Glycolate & 0.000 & 0.121 & 0.000 & 0.000 & 0.000 \\
\hline Hydroxide & 0.499 & 0.116 & 1.765 & 0.631 & 0.000 \\
\hline Iminodiacetic & 0.000 & 0.002 & 0.000 & 0.000 & 0.000 \\
Acid & & & & & \\
\hline Iron & 0.000 & 0.000 & 0.000 & 0.000 & 0.042 \\
\hline Lanthanum & 0.000 & 0.000 & 0.000 & 0.000 & 0.001 \\
\hline Magnesium & 0.000 & 0.000 & 0.000 & 0.000 & 0.001 \\
\hline Manganese & 0.000 & 0.000 & 0.000 & 0.000 & 0.001 \\
\hline Nickel & 0.000 & 0.000 & 0.000 & 0.000 & 0.003 \\
\hline Nitrate & 0.853 & 0.290 & 0.003 & 0.002 & 2.000 \\
\hline Nitrite & 0.670 & 0.699 & 0.009 & 0.004 & 0.000 \\
\hline Oxalate & 0.012 & 0.058 & 0.000 & 0.000 & 0.000 \\
\hline Phosphate & 0.016 & 0.006 & 0.002 & 0.002 & 0.001 \\
\hline Potassium & 0.000 & 0.086 & 0.000 & 0.000 & 0.000 \\
\hline Silicon & 0.004 & 0.000 & 0.004 & 0.002 & 0.003 \\
\hline Sodium & $\mathbf{2 . 9 5 2}$ & $\mathbf{2 . 9 4 0}$ & $\mathbf{2 . 3 5 7}$ & $\mathbf{0 . 8 9 7}$ & $\mathbf{0 . 0 0 9}$ \\
\hline Sulfate & 0.018 & 0.183 & 0.002 & 0.001 & 0.000 \\
\hline Zirconium & 0.000 & 0.000 & 0.000 & 0.000 & 0.004 \\
\hline Acid (H+) & 0.000 & 0.000 & 0.000 & 0.000 & 2.000 \\
\hline $\begin{array}{l}\text { Cutoff } \\
\text { Concentration }\end{array}$ & $\mathrm{NA}$ & 0.001 & 0.001 & 0.001 & $\mathrm{NA}$ \\
\hline & & & & & \\
\hline
\end{tabular}


Table A- 2. Target Compositions of Envelope A Recycles

\begin{tabular}{|c|c|c|c|c|c|c|c|c|c|c|}
\hline \multirow[b]{2}{*}{$\begin{array}{l}\text { Vol \% } \\
\text { MOGC }\end{array}$} & \multicolumn{4}{|c|}{ UF1: Leach Option } & \multicolumn{2}{|c|}{$\begin{array}{l}\text { UF2: No acid } \\
\text { cleaning }\end{array}$} & \multicolumn{4}{|c|}{ UF3: No Leach Option } \\
\hline & 0 & 25 & 50 & 75 & 0 & 25 & 0 & 25 & 50 & 75 \\
\hline Component & Molar & Molar & Molar & Molar & Molar & Molar & Molar & Molar & Molar & Molar \\
\hline Aluminum & 0.158 & 0.119 & 0.080 & 0.042 & 0.236 & 0.178 & 0.128 & 0.097 & 0.065 & 0.034 \\
\hline Boron & 0 & 0.012 & 0.024 & 0.036 & 0 & 0.012 & 0 & 0.012 & 0.024 & 0.036 \\
\hline Cadmium & 0.001 & 0.001 & 0.000 & 0.000 & 0.000 & 0.000 & 0.001 & 0.001 & 0.000 & 0.000 \\
\hline Carbonate & 0.073 & 0.055 & 0.037 & 0.018 & 0.116 & 0.087 & 0.092 & 0.069 & 0.046 & 0.023 \\
\hline Chloride & 0.022 & 0.020 & 0.018 & 0.017 & 0.035 & 0.030 & 0.026 & 0.024 & 0.021 & 0.018 \\
\hline Fluoride & 0.020 & 0.016 & 0.012 & 0.008 & 0.032 & 0.025 & 0.030 & 0.024 & 0.017 & 0.011 \\
\hline Hydroxide & 0.441 & 0.331 & 0.221 & 0.110 & 0.642 & 0.481 & 0.384 & 0.288 & 0.192 & 0.096 \\
\hline Iron & 0.009 & 0.007 & 0.005 & 0.004 & 0.000 & 0.000 & 0.009 & 0.007 & 0.005 & 0.004 \\
\hline Nickel & 0.001 & 0.001 & 0.000 & 0.000 & 0.000 & 0.000 & 0.001 & 0.001 & 0.000 & 0.000 \\
\hline Nitrate & 0.693 & 0.521 & 0.349 & 0.177 & 0.400 & 0.301 & 0.816 & 0.614 & 0.411 & 0.208 \\
\hline Nitrite & 0.199 & 0.149 & 0.099 & 0.050 & 0.316 & 0.237 & 0.295 & 0.221 & 0.148 & 0.074 \\
\hline Oxalate & 0.004 & 0.003 & 0.002 & 0.001 & 0.006 & 0.004 & 0.005 & 0.004 & 0.003 & 0.002 \\
\hline Phosphate & 0.005 & 0.005 & 0.004 & 0.004 & 0.008 & 0.007 & 0.007 & 0.006 & 0.005 & 0.004 \\
\hline Silicon & 0.003 & 0.003 & 0.003 & 0.003 & 0.003 & 0.003 & 0.002 & 0.002 & 0.003 & 0.003 \\
\hline Sodium & 1.281 & 0.963 & 0.646 & 0.328 & 1.952 & 1.467 & 1.497 & 1.125 & 0.753 & 0.382 \\
\hline Sulfate & 0.006 & 0.005 & 0.005 & 0.004 & 0.009 & 0.008 & 0.008 & 0.007 & 0.006 & 0.005 \\
\hline Zirconium & 0.001 & 0.001 & 0.000 & 0.000 & 0.000 & 0.000 & 0.001 & 0.001 & 0.000 & 0.000 \\
\hline
\end{tabular}


Table A- 3. Target Compositions of Envelope B Recycle

\begin{tabular}{|l|c|c|}
\cline { 2 - 3 } \multicolumn{1}{c|}{} & \multicolumn{2}{l}{ UF1: Leach Option } \\
\hline Vol \% MOGC & 0 & 50 \\
\hline Component & Molar & Molar \\
\hline & & \\
\hline Acetate & 0.003 & 0.002 \\
\hline Aluminum & 0.083 & 0.043 \\
\hline Boron & 0.001 & 0.024 \\
\hline Carbonate & 0.164 & 0.082 \\
\hline Chloride & 0.004 & 0.009 \\
\hline Chromium & 0.004 & 0.002 \\
\hline Citrate & 0.007 & 0.003 \\
\hline Fluoride & 0.016 & 0.010 \\
\hline Formate & 0.031 & 0.015 \\
\hline Glycolate & 0.034 & 0.017 \\
\hline Hydroxide & 1.059 & 0.529 \\
\hline Iminodiacetic & 0.001 & 0.000 \\
Acid & & \\
\hline Iron & 0.009 & 0.005 \\
\hline Nickel & 0.001 & 0.000 \\
\hline Nitrate & 0.507 & 0.256 \\
\hline Nitrite & 0.199 & 0.100 \\
\hline Oxalate & 0.016 & 0.008 \\
\hline Phosphate & 0.002 & 0.003 \\
\hline Potassium & 0.024 & 0.012 \\
\hline Silicon & 0.001 & 0.002 \\
\hline Sodium & $\mathbf{1 . 9 7 1}$ & $\mathbf{0 . 9 9 1}$ \\
\hline Sulfate & 0.052 & 0.028 \\
\hline Zirconium & 0.001 & 0.000 \\
\hline & & \\
\hline
\end{tabular}


Table A- 4. Composition of Envelope C Recycle

\begin{tabular}{|l|c|c|}
\hline $\mathrm{Al}$ & molar & $8.26 \mathrm{E}-02$ \\
\hline $\mathrm{Ca}$ & molar & $7.66 \mathrm{E}-04$ \\
\hline $\mathrm{Cd}$ & molar & $9.25 \mathrm{E}-05$ \\
\hline $\mathrm{Cl}$ & molar & $2.67 \mathrm{E}-02$ \\
\hline $\mathrm{Cr}$ & molar & $4.88 \mathrm{E}-04$ \\
\hline $\mathrm{Cu}$ & molar & $2.11 \mathrm{E}-05$ \\
\hline $\mathrm{Fe}$ & molar & $3.40 \mathrm{E}-06$ \\
\hline $\mathrm{K}$ & molar & $1.12 \mathrm{E}-02$ \\
\hline $\mathrm{Mn}$ & molar & $1.82 \mathrm{E}-05$ \\
\hline $\mathrm{Na}$ & molar & $1.98 \mathrm{E}+00$ \\
\hline $\mathrm{Ni}$ & molar & $1.12 \mathrm{E}-03$ \\
\hline $\mathrm{NO} 3$ (Nitrate) & molar & $5.44 \mathrm{E}-01$ \\
\hline $\mathrm{P}$ & molar & $2.56 \mathrm{E}-02$ \\
\hline $\mathrm{PO} 4$ (Phosphate) & molar & $2.52 \mathrm{E}-02$ \\
\hline $\mathrm{Pb}$ & molar & $2.65 \mathrm{E}-05$ \\
\hline $\mathrm{S}$ & molar & $2.79 \mathrm{E}-02$ \\
\hline SO4 (Sulfate) & molar & $2.56 \mathrm{E}-02$ \\
\hline Sr & molar & $1.42 \mathrm{E}-04$ \\
\hline $\begin{array}{l}\text { Total Organic } \\
\text { Carbon }\end{array}$ & molar & $2.43 \mathrm{E}-01$ \\
\hline $\begin{array}{l}\text { Total Inorganic } \\
\text { Carbon }\end{array}$ & molar & $2.06 \mathrm{E}-01$ \\
\hline Total Solids & wt\% & $1.19 \mathrm{E}+01$ \\
\hline Density & g/mL & $1.09 \mathrm{E}+00$ \\
\hline
\end{tabular}


Table A- 5. Composition of AZ-102

\begin{tabular}{|l|c|c|}
\hline Component & $\begin{array}{c}3.5 \text { wt } \% \\
\text { Insoluble } \\
\text { Solids }\end{array}$ & $\begin{array}{c}7.5 \text { wt\% } \\
\text { Insoluble } \\
\text { Solids }\end{array}$ \\
\hline $\mathrm{Al}$ & $9.52 \mathrm{E}-02$ & $1.89 \mathrm{E}-01$ \\
\hline $\mathrm{Ba}$ & $6.36 \mathrm{E}-05$ & $1.36 \mathrm{E}-04$ \\
\hline $\mathrm{Ca}$ & $5.34 \mathrm{E}-04$ & $1.07 \mathrm{E}-03$ \\
\hline $\mathrm{Cd}$ & $5.98 \mathrm{E}-03$ & $1.21 \mathrm{E}-02$ \\
\hline $\mathrm{Ce}$ & $2.01 \mathrm{E}-04$ & $4.21 \mathrm{E}-04$ \\
\hline $\mathrm{Cr}$ & $1.63 \mathrm{E}-02$ & $1.93 \mathrm{E}-02$ \\
\hline $\mathrm{Cu}$ & $2.25 \mathrm{E}-05$ & $2.25 \mathrm{E}-05$ \\
\hline $\mathrm{Fe}$ & $7.52 \mathrm{E}-02$ & $1.61 \mathrm{E}-01$ \\
\hline $\mathrm{K}$ & $9.97 \mathrm{E}-02$ & $1.15 \mathrm{E}-01$ \\
\hline $\mathrm{La}$ & $9.21 \mathrm{E}-03$ & $1.97 \mathrm{E}-02$ \\
\hline $\mathrm{Li}$ & $1.87 \mathrm{E}-03$ & $3.72 \mathrm{E}-03$ \\
\hline $\mathrm{Mg}$ & $9.06 \mathrm{E}-04$ & $1.94 \mathrm{E}-03$ \\
\hline $\mathrm{Na}$ & $2.94 \mathrm{E}+00$ & $3.38 \mathrm{E}+00$ \\
\hline $\mathrm{Ni}$ & $5.15 \mathrm{E}-03$ & $1.08 \mathrm{E}-02$ \\
\hline $\mathrm{P}$ & $1.37 \mathrm{E}-02$ & $1.67 \mathrm{E}-02$ \\
\hline $\mathrm{S}$ & $1.99 \mathrm{E}-01$ & $2.30 \mathrm{E}-01$ \\
\hline $\mathrm{Sn}$ & $2.07 \mathrm{E}-03$ & $2.42 \mathrm{E}-03$ \\
\hline $\mathrm{Sr}$ & $2.17 \mathrm{E}-05$ & $2.17 \mathrm{E}-05$ \\
\hline $\mathrm{Si}$ & $4.90 \mathrm{E}-03$ & $1.04 \mathrm{E}-02$ \\
\hline $\mathrm{Ti}$ & $1.23 \mathrm{E}-05$ & $1.23 \mathrm{E}-05$ \\
\hline $\mathrm{W}$ & $9.51 \mathrm{E}-06$ & $9.51 \mathrm{E}-06$ \\
\hline $\mathrm{Zn}$ & $1.84 \mathrm{E}-04$ & $3.95 \mathrm{E}-04$ \\
\hline $\mathrm{Zr}$ & $6.06 \mathrm{E}-03$ & $1.30 \mathrm{E}-02$ \\
\hline $\mathrm{HCO}$ & $1.04 \mathrm{E}-01$ & $1.04 \mathrm{E}-01$ \\
\hline $\mathrm{NO} 2$ & $6.76 \mathrm{E}-01$ & $6.76 \mathrm{E}-01$ \\
\hline $\mathrm{NO} 3$ & $2.73 \mathrm{E}-01$ & $2.73 \mathrm{E}-01$ \\
\hline $\mathrm{PO} 4$ & $8.04 \mathrm{E}-03$ & $8.04 \mathrm{E}-03$ \\
\hline $\mathrm{SO} 4$ & $1.48 \mathrm{E}-01$ & $1.48 \mathrm{E}-01$ \\
\hline $\mathrm{C} 2 \mathrm{O} 4$ & $2.01 \mathrm{E}-02$ & $2.01 \mathrm{E}-02$ \\
\hline $\mathrm{CO} 3$ & $6.40 \mathrm{E}-01$ & $5.25 \mathrm{E}-01$ \\
\hline $\mathrm{OH}$ & $5.17 \mathrm{E}-01$ & $1.25 \mathrm{E}+00$ \\
\hline
\end{tabular}


Table A- 6. Composition of Envelope C Waste Simulants

\begin{tabular}{|c|c|c|c|}
\hline Component & units & AN-102 & AN-107 \\
\hline Sodium & molar & $7.10 \mathrm{E}+00$ & $8.33 E+00$ \\
\hline Aluminum & molar & 4.05E-01 & $2.31 \mathrm{E}+00$ \\
\hline Phosporus & molar & $5.18 \mathrm{E}-02$ & $2.96 \mathrm{E}-01$ \\
\hline Silicon & molar & $3.18 \mathrm{E}-04$ & $0.00 \mathrm{E}+00$ \\
\hline Zinc & molar & 6.83E-05 & 3.90E-04 \\
\hline Potassium & molar & 4.52E-02 & $2.58 \mathrm{E}-01$ \\
\hline Sulfur & molar & 1.17E-01 & $6.68 \mathrm{E}-01$ \\
\hline Cadmium & molar & 4.83E-04 & $2.76 \mathrm{E}-03$ \\
\hline Chromium & molar & 4.31E-03 & 2.46E-02 \\
\hline Iron & molar & $6.66 \mathrm{E}-04$ & $3.80 \mathrm{E}-03$ \\
\hline Manganese & molar & 4.74E-04 & $2.71 \mathrm{E}-03$ \\
\hline Nickel & molar & $6.33 \mathrm{E}-03$ & $3.61 \mathrm{E}-02$ \\
\hline Zirconium & molar & 1.30E-04 & 7.45E-04 \\
\hline \begin{tabular}{|l} 
Fluoride \\
\end{tabular} & molar & 8.05E-02 & $4.60 \mathrm{E}-01$ \\
\hline Nitrite & molar & $1.28 \mathrm{E}+00$ & $7.30 E+00$ \\
\hline Phosphate & molar & $5.18 \mathrm{E}-02$ & $2.96 \mathrm{E}-01$ \\
\hline Oxalate & molar & $4.68 \mathrm{E}-03$ & 2.67E-02 \\
\hline Sulfate & molar & 1.17E-01 & 6.68E-01 \\
\hline Nitrate & molar & $2.41 \mathrm{E}+00$ & $1.38 \mathrm{E}+01$ \\
\hline Chloride & molar & $1.20 \mathrm{E}-01$ & 6.86E-01 \\
\hline Formate & molar & $1.66 \mathrm{E}-01$ & 9.51E-01 \\
\hline Carbonate & molar & 8.14E-01 & $4.65 E+00$ \\
\hline Hydroxide & molar & 3.53E-01 & $2.02 \mathrm{E}+00$ \\
\hline Ammonium & molar & $7.26 \mathrm{E}-03$ & 4.15E-02 \\
\hline Boron & molar & 3.03E-03 & $1.73 \mathrm{E}-02$ \\
\hline Calcium & molar & 1.09E-02 & 6.22E-02 \\
\hline Copper & molar & 3.40E-04 & 1.94E-03 \\
\hline Lanthanum & molar & 1.02E-04 & 5.81E-04 \\
\hline Lead & molar & 7.97E-04 & 4.55E-03 \\
\hline Molybdenum & molar & $4.19 \mathrm{E}-04$ & $2.39 \mathrm{E}-03$ \\
\hline Neodymium & molar & 1.96E-04 & $1.12 \mathrm{E}-03$ \\
\hline Acetate & molar & 1.17E-02 & 6.66E-02 \\
\hline Citric Acid & molar & $2.19 \mathrm{E}-02$ & $1.25 \mathrm{E}-01$ \\
\hline Ethylenediaminetetraacetic acid & molar & 8.56E-03 & 4.89E-02 \\
\hline Glycolate & molar & 1.24E-01 & 7.09E-01 \\
\hline Iminodiacetic Acid & molar & 3.05E-02 & $1.74 \mathrm{E}-01$ \\
\hline n-Hydroxyethylenediaminetriacetic acid & molar & 1.19E-03 & 6.79E-03 \\
\hline Nitrilotriacetic Acid & molar & 1.23E-03 & $7.00 \mathrm{E}-03$ \\
\hline Sodium Gluconate & molar & $6.72 \mathrm{E}-03$ & 3.84E-02 \\
\hline Cesium & molar & 1.06E-04 & $0.00 \mathrm{E}+00$ \\
\hline Rubidium & molar & 8.70E-05 & $0.00 \mathrm{E}+00$ \\
\hline Tungsten & molar & $8.13 \mathrm{E}-04$ & $0.00 \mathrm{E}+00$ \\
\hline Strontium & molar & $2.55 \mathrm{E}-05$ & $0.00 \mathrm{E}+00$ \\
\hline Adipic Acid & molar & 1.52E-03 & $0.00 \mathrm{E}+00$ \\
\hline Azelaic Acid & molar & 4.93E-03 & $0.00 E+00$ \\
\hline Glutaric Acid & molar & 4.46E-04 & $0.00 E+00$ \\
\hline Suberic Acid & molar & 9.36E-03 & $0.00 E+00$ \\
\hline Succinic Acid & molar & $2.76 \mathrm{E}-04$ & $0.00 \mathrm{E}+00$ \\
\hline
\end{tabular}


Table A- 7. Compositions of OLI Validation Points for Envelope A

\begin{tabular}{|c|c|c|c|c|c|c|c|}
\hline OLI \# & 5 & 11 & 13 & 21 & 25 & 30 & 35 \\
\hline Sample \# & W-0651 & W-0652 & W-0653 & W-0654 & W-0655 & W-0656 & W-0657 \\
\hline & Molar & Molar & Molar & Molar & Molar & Molar & Molar \\
\hline$\overline{A l}$ & $243 F_{-} 01$ & $247 F_{-} 01$ & $35 \mathrm{~F}_{-} 01$ & $233 F_{-01}$ & $30 F_{-01}$ & $05 F+00$ & $33 F_{-01}$ \\
\hline $\mathrm{Ca}$ & $0.00 \mathrm{E}+00$ & $0.00 \mathrm{E}+00$ & $0.00 \mathrm{E}+00$ & $7.38 \mathrm{E}-03$ & $7.39 \mathrm{E}-03$ & $6.02 \mathrm{E}-03$ & $5.93 \mathrm{E}-03$ \\
\hline $\mathrm{Cl}$ & $1.20 \mathrm{E}-01$ & $1.21 \mathrm{E}-01$ & $1.14 \mathrm{E}-01$ & $5.42 \mathrm{E}-01$ & 5.34E-01 & $4.93 \mathrm{E}-01$ & $4.52 \mathrm{E}-01$ \\
\hline $\mathrm{CO} 3$ & 3.82E-02 & $3.88 \mathrm{E}-02$ & 3.64E-02 & $3.53 \mathrm{E}-02$ & 3.49E-02 & $3.18 \mathrm{E}-02$ & $3.56 \mathrm{E}-02$ \\
\hline$F$ & $2.77 \mathrm{E}-01$ & $1.10 \mathrm{E}-02$ & 1.04E-02 & 1.84E-02 & $2.53 \mathrm{E}-01$ & $2.57 \mathrm{E}-01$ & $2.56 \mathrm{E}-01$ \\
\hline $\mathrm{Fe}$ & $2.73 E-05$ & $1.30 \mathrm{E}-04$ & $2.24 \mathrm{E}-05$ & $9.16 \mathrm{E}-04$ & $8.48 \mathrm{E}-04$ & $1.24 \mathrm{E}-03$ & $6.82 \mathrm{E}-04$ \\
\hline $\bar{K}$ & $0.00 \mathrm{E}+00$ & $0.00 \mathrm{E}+00$ & $0.00 \mathrm{E}+00$ & $1.40 \mathrm{E}-01$ & $1.37 \mathrm{E}-01$ & $1.27 \mathrm{E}-01$ & $1.10 \mathrm{E}-01$ \\
\hline $\mathrm{Mg}$ & $2.33 \mathrm{E}-06$ & 1.07E-05 & 1.91E-06 & $2.24 \mathrm{E}-03$ & $2.24 \mathrm{E}-03$ & $1.86 \mathrm{E}-03$ & $1.80 \mathrm{E}-03$ \\
\hline$\overline{M n}$ & 1.94E-06 & $9.21 \mathrm{E}-06$ & $1.60 \mathrm{E}-06$ & $6.74 \mathrm{E}-06$ & $2.87 \mathrm{E}-06$ & $3.53 \mathrm{E}-05$ & $2.48 \mathrm{E}-06$ \\
\hline $\mathrm{Na}$ & $5.90 \mathrm{E}+00$ & $6.09 \mathrm{E}+00$ & $5.62 \mathrm{E}+00$ & $5.92 \mathrm{E}+00$ & $5.78 \mathrm{E}+00$ & $5.84 \mathrm{E}+00$ & $5.80 \mathrm{E}+00$ \\
\hline $\mathrm{Ni}$ & $5.71 \mathrm{E}-06$ & $2.71 \mathrm{E}-05$ & $4.69 \mathrm{E}-06$ & $1.98 \mathrm{E}-05$ & $8.42 \mathrm{E}-06$ & $1.01 \mathrm{E}-04$ & $7.30 \mathrm{E}-06$ \\
\hline NO2 & $1.81 \mathrm{E}+00$ & $8.70 \mathrm{E}-01$ & $1.72 \mathrm{E}+00$ & $8.61 \mathrm{E}-01$ & $1.72 \mathrm{E}+00$ & $7.76 \mathrm{E}-01$ & $1.74 \mathrm{E}+00$ \\
\hline $\mathrm{NO3}$ & $1.17 \mathrm{E}+00$ & $1.21 \mathrm{E}+00$ & $2.14 \mathrm{E}+00$ & $1.11 \mathrm{E}+00$ & $1.09 \mathrm{E}+00$ & $1.10 \mathrm{E}+00$ & $1.10 \mathrm{E}+00$ \\
\hline $\mathrm{OH}$ & $2.87 \mathrm{E}+00$ & $4.19 \mathrm{E}+00$ & $2.06 \mathrm{E}+00$ & $3.84 \mathrm{E}+00$ & $2.65 \mathrm{E}+00$ & $6.24 \mathrm{E}+00$ & $2.69 \mathrm{E}+00$ \\
\hline Oxalate & $2.38 \mathrm{E}-02$ & $2.54 \mathrm{E}-02$ & $2.23 \mathrm{E}-02$ & $2.18 \mathrm{E}-02$ & $2.11 \mathrm{E}-02$ & $2.68 \mathrm{E}-02$ & $2.16 \mathrm{E}-02$ \\
\hline $\mathrm{PO4}$ & 4.05E-02 & 6.30E-02 & 7.06E-03 & 5.57E-02 & 3.64E-02 & $6.16 \mathrm{E}-03$ & $3.71 \mathrm{E}-02$ \\
\hline Si & $7.46 \mathrm{E}-03$ & $7.59 \mathrm{E}-03$ & $7.12 \mathrm{E}-03$ & $2.03 E-02$ & 1.97E-02 & 1.69E-02 & $1.73 \mathrm{E}-02$ \\
\hline SO4 & $6.38 \mathrm{E}-02$ & $6.47 \mathrm{E}-02$ & $6.08 \mathrm{E}-02$ & $6.30 \mathrm{E}-02$ & $6.23 \mathrm{E}-02$ & $5.68 \mathrm{E}-02$ & $6.26 \mathrm{E}-02$ \\
\hline$Z n$ & $0.00 \mathrm{E}+00$ & $0.00 \mathrm{E}+00$ & $0.00 \mathrm{E}+00$ & 4.19E-03 & $4.12 \mathrm{E}-03$ & 3.82E-03 & $3.30 \mathrm{E}-03$ \\
\hline $\mathrm{Zr}$ & 8.47E-06 & 4.01E-05 & 6.95E-06 & 2.93E-05 & 1.25E-05 & $1.54 \mathrm{E}-04$ & $1.08 \mathrm{E}-05$ \\
\hline OLI \# & 53 & 61 & 10 & 20 & 26 & 33 & \\
\hline Sample \# & W-0658 & W-0659 & W-0660 & W-0661 & W-0662 & W-0663 & \\
\hline & Molar & Molar & Molar & Molar & Molar & Molar & \\
\hline & & & & & & & \\
\hline $\mathrm{Al}$ & 2.91E-01 & 2.84E-01 & $1.13 \mathrm{E}+00$ & $1.13 \mathrm{E}+00$ & $2.19 \mathrm{E}-01$ & $2.30 \mathrm{E}-01$ & \\
\hline $\mathrm{Ca}$ & $0.00 \mathrm{E}+00$ & $8.11 \mathrm{E}-03$ & $0.00 \mathrm{E}+00$ & $0.00 \mathrm{E}+00$ & $6.85 \mathrm{E}-03$ & 5.83E-03 & \\
\hline $\mathrm{Cl}$ & $1.44 \mathrm{E}-01$ & 5.97E-01 & $1.08 \mathrm{E}-01$ & $1.08 \mathrm{E}-01$ & $4.95 \mathrm{E}-01$ & 4.41E-01 & \\
\hline $\mathrm{CO} 3$ & 4.59E-02 & 4.33E-02 & 3.44E-02 & 3.44E-02 & 6.54E-01 & 3.40E-02 & \\
\hline $\mathrm{F}$ & 1.31E-02 & $2.13 \mathrm{E}-02$ & $3.75 \mathrm{E}-01$ & $3.75 \mathrm{E}-01$ & $2.32 \mathrm{E}-01$ & $1.65 \mathrm{E}-02$ & \\
\hline $\mathrm{Fe}$ & $3.16 \mathrm{E}-06$ & 8.87E-04 & 5.70E-04 & 5.70E-04 & 7.95E-04 & 6.79E-04 & \\
\hline $\mathrm{K}$ & $0.00 \mathrm{E}+00$ & 1.49E-01 & $0.00 \mathrm{E}+00$ & $0.00 \mathrm{E}+00$ & $1.28 \mathrm{E}-01$ & $1.08 \mathrm{E}-01$ & \\
\hline $\mathrm{Mg}$ & $2.71 \mathrm{E}-07$ & $2.46 \mathrm{E}-03$ & 4.16E-05 & 4.16E-05 & $2.08 \mathrm{E}-03$ & 1.77E-03 & \\
\hline $\mathrm{Mn}$ & $2.25 \mathrm{E}-07$ & $6.28 \mathrm{E}-07$ & 4.05E-05 & 4.05E-05 & 3.17E-06 & 3.01E-06 & \\
\hline $\mathrm{Na}$ & $7.04 \mathrm{E}+00$ & $7.07 \mathrm{E}+00$ & $6.07 \mathrm{E}+00$ & $6.07 \mathrm{E}+00$ & $5.34 \mathrm{E}+00$ & $5.58 \mathrm{E}+00$ & \\
\hline $\mathrm{Ni}$ & 6.60E-07 & 1.85E-06 & 1.14E-04 & 1.14E-04 & 9.32E-06 & 8.83E-06 & \\
\hline $\mathrm{NO} 2$ & $2.17 \mathrm{E}+00$ & $1.05 E+00$ & 7.71E-01 & 7.71E-01 & 7.82E-01 & $1.66 \mathrm{E}+00$ & \\
\hline NO3 & $2.69 \mathrm{E}+00$ & $1.34 \mathrm{E}+00$ & $1.18 \mathrm{E}+00$ & $1.18 \mathrm{E}+00$ & $1.16 \mathrm{E}+00$ & $2.02 E+00$ & \\
\hline $\mathrm{OH}$ & $2.56 \mathrm{E}+00$ & $4.62 \mathrm{E}+00$ & $6.74 \mathrm{E}+00$ & $6.74 \mathrm{E}+00$ & $1.86 \mathrm{E}+00$ & $1.97 E+00$ & \\
\hline Oxalate & $2.82 \mathrm{E}-02$ & $2.53 \mathrm{E}-02$ & $2.94 \mathrm{E}-02$ & $2.94 \mathrm{E}-02$ & 1.97E-02 & 1.99E-02 & \\
\hline $\mathrm{PO4}$ & 8.89E-03 & $5.61 \mathrm{E}-02$ & $6.66 \mathrm{E}-03$ & $6.66 \mathrm{E}-03$ & $3.34 \mathrm{E}-02$ & 6.59E-03 & \\
\hline
\end{tabular}




\section{Appendix B. Apparatus Diagrams}

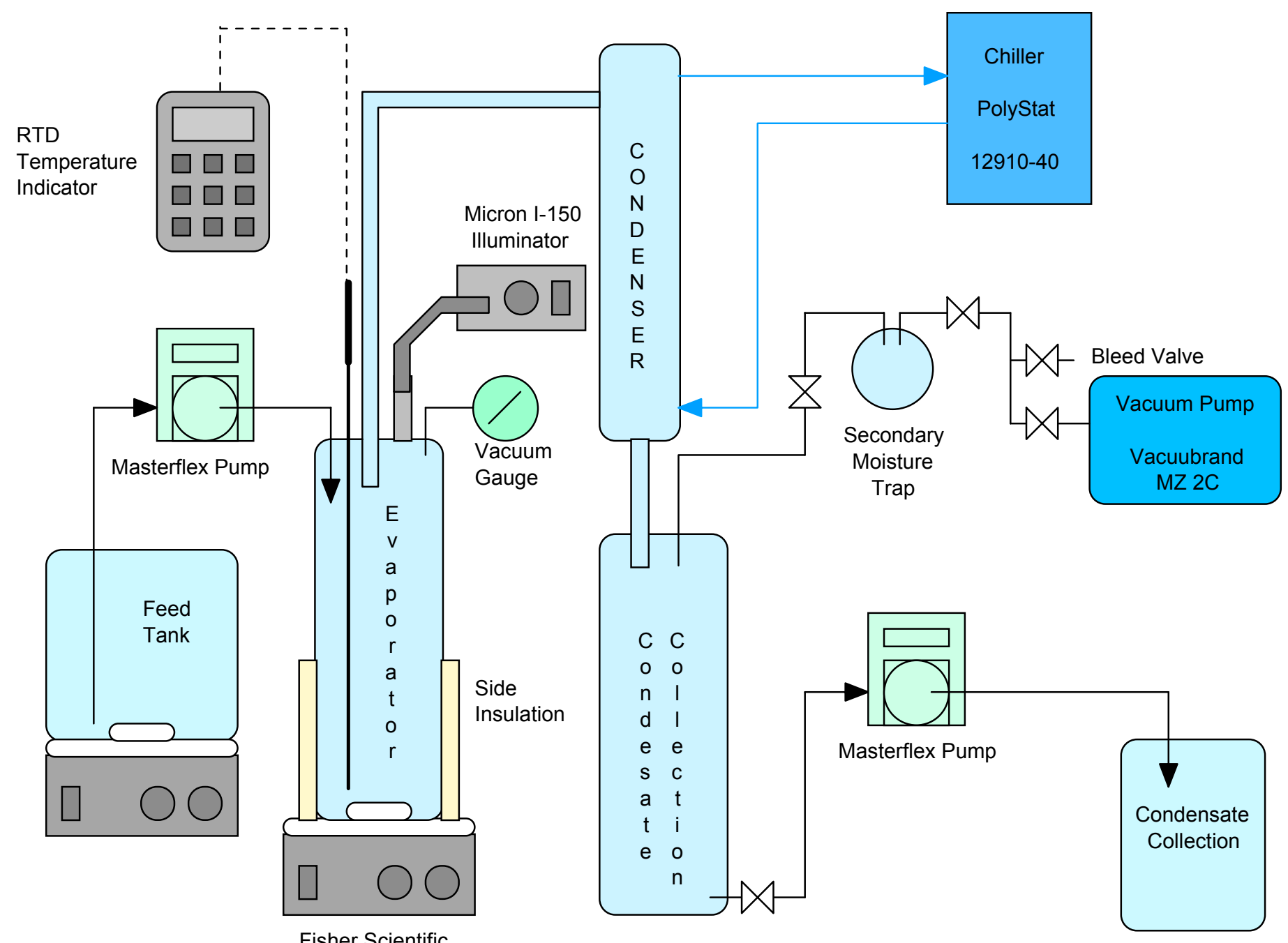

Fisher Scientific IR1400 Infrared Hotplate

Figure B- 1. Apparatus for MOGC Evaporation 


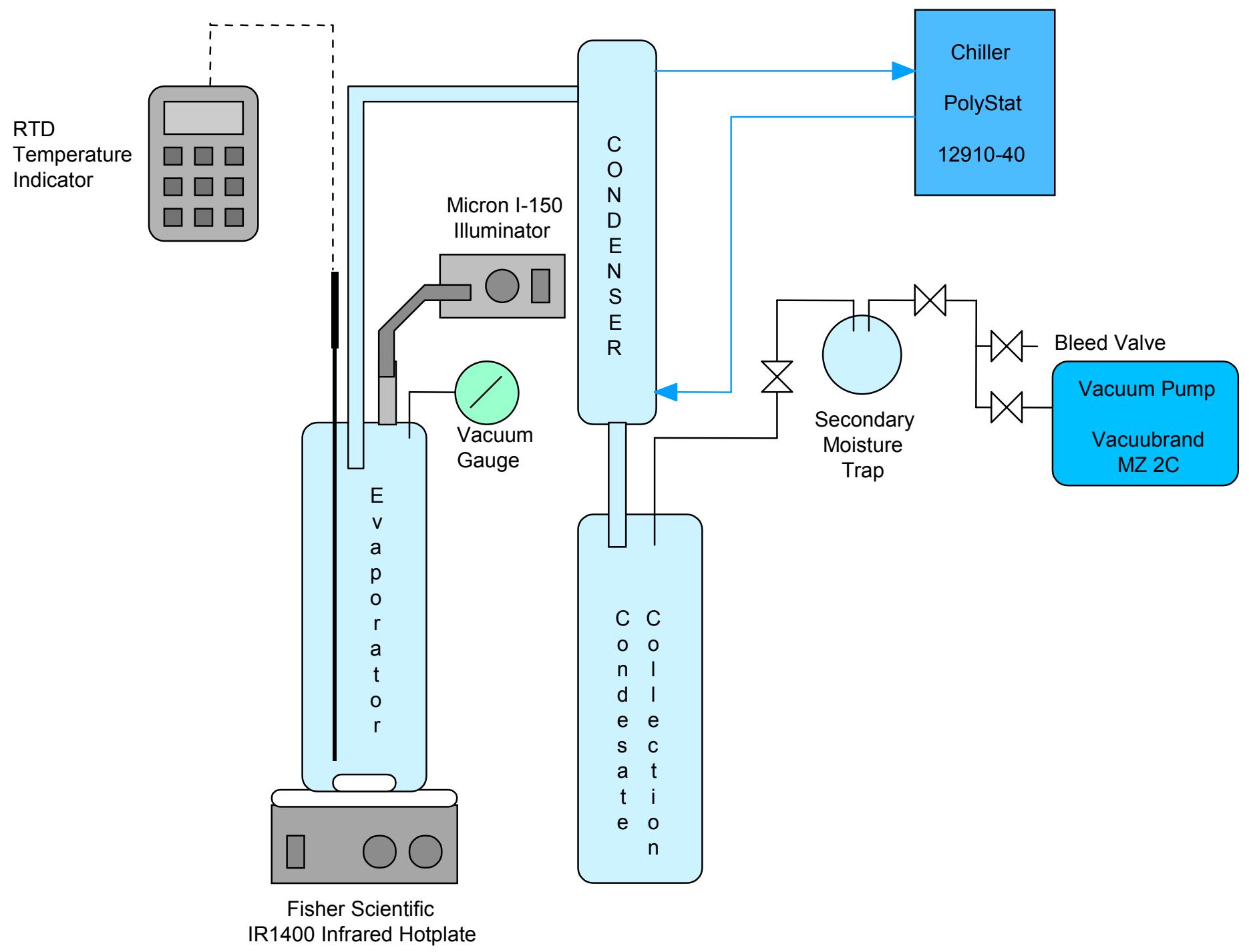

Figure B- 2. Apparatus for Envelope A and C Recycle Evaporation 


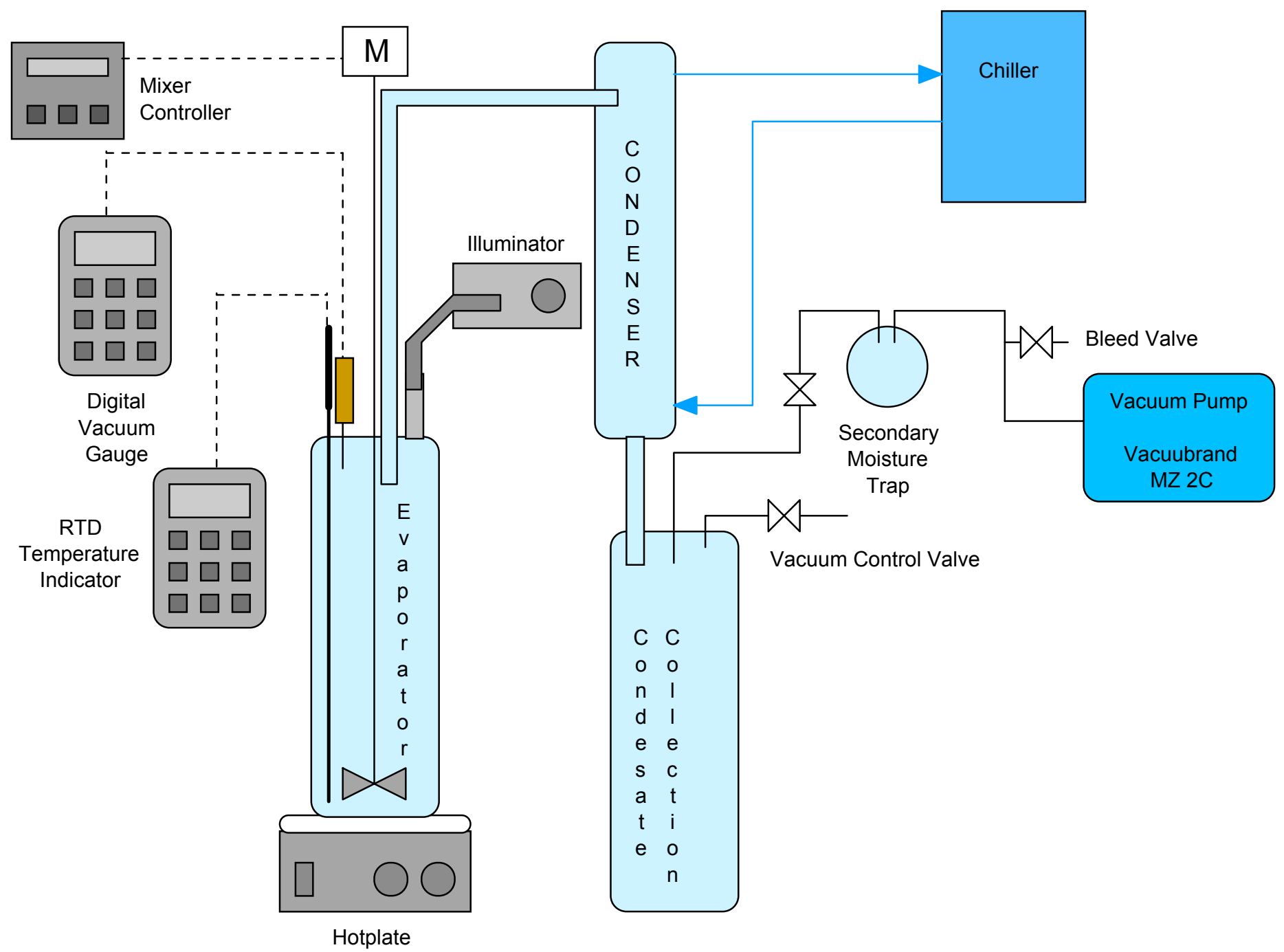

Figure B- 3. Apparatus for Envelope B Evaporations 


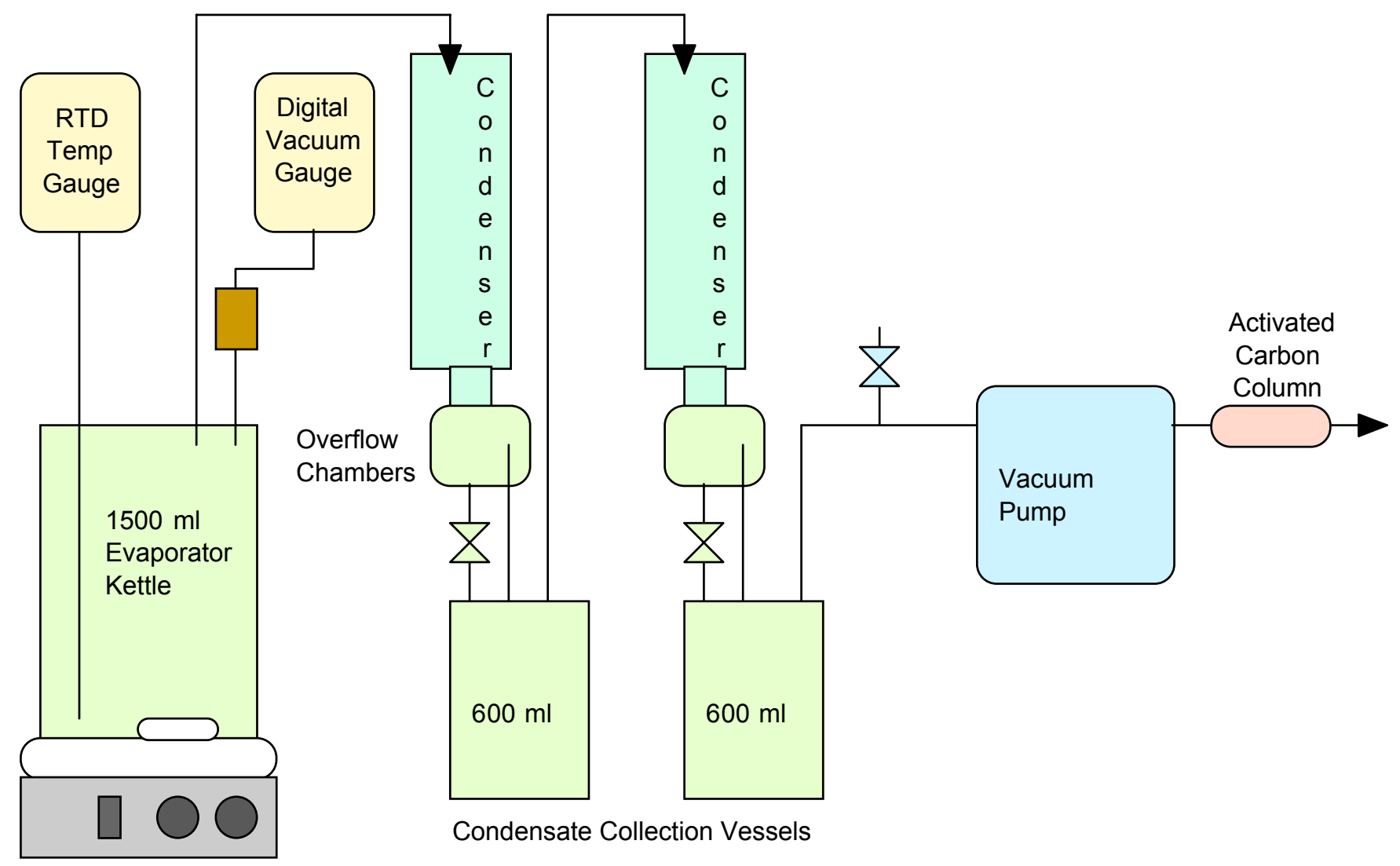

Hotplate

Figure B- 4. Apparatus for Evaporation Runs with Mercury Spikes 


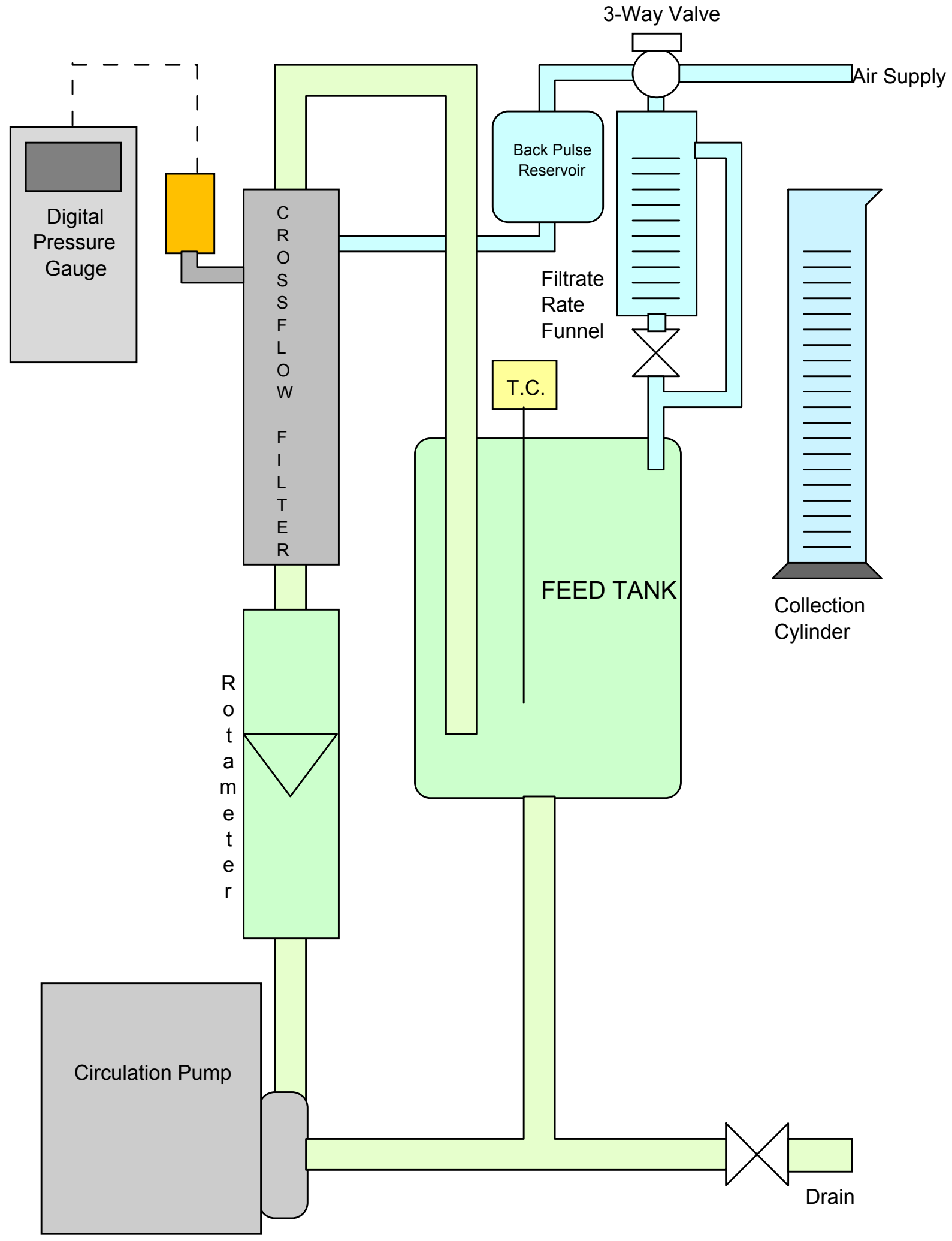

Figure B- 5. Apparatus for Cross-Flow Filtration Tests 


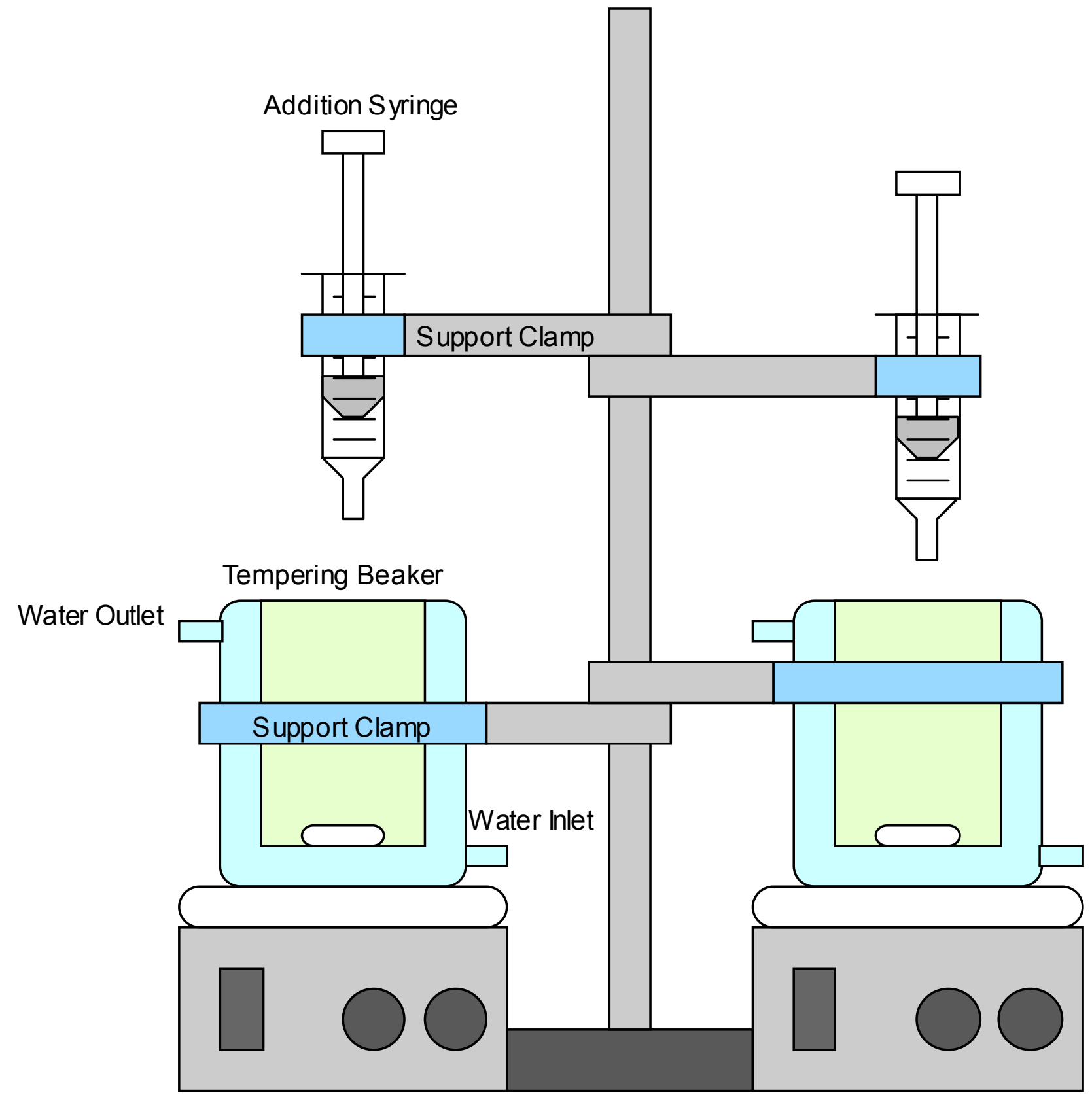

Figure B- 6. Apparatus for Envelope C Precipitations 


\section{Appendix C. Physical Property Charts}

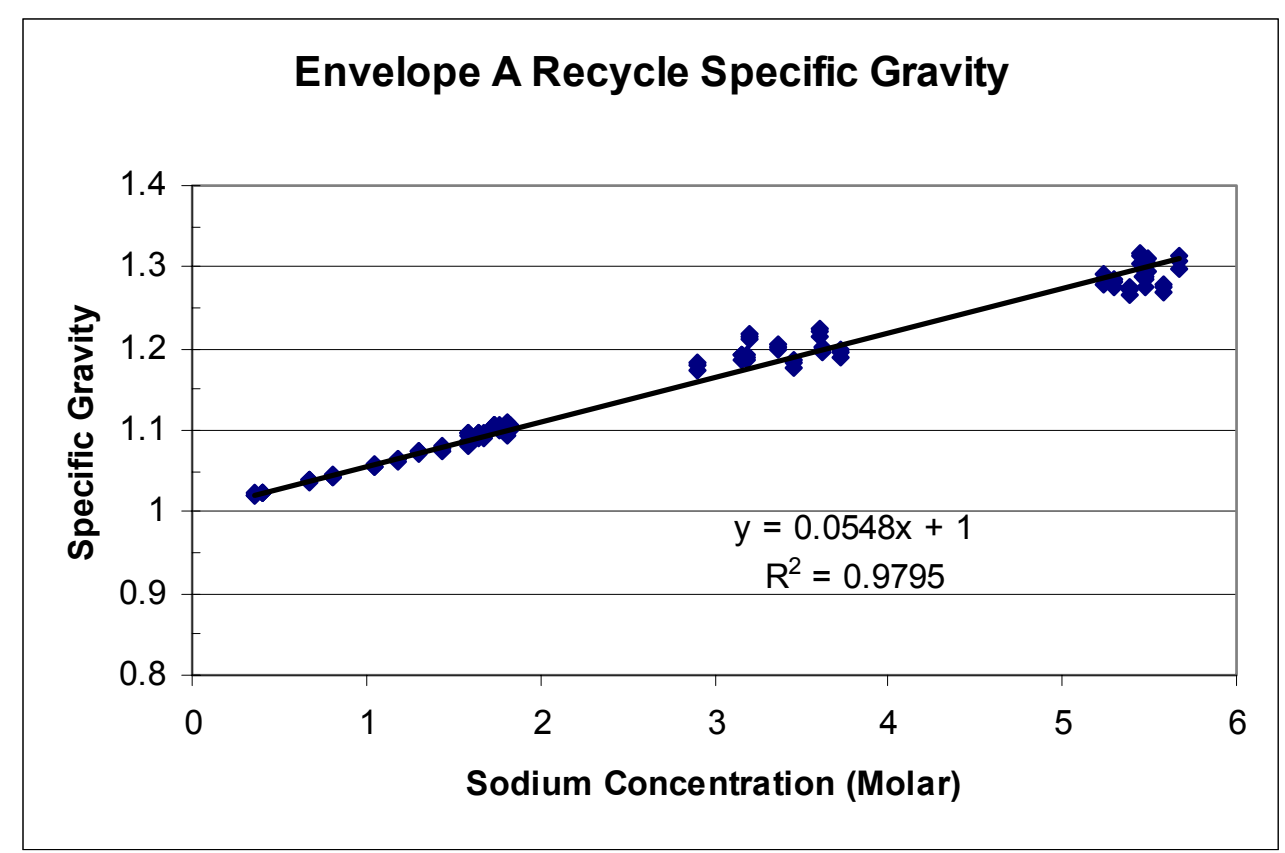

Figure C-1. Envelope A Recycle Specific Gravity @ $25^{\circ} \mathrm{C}$

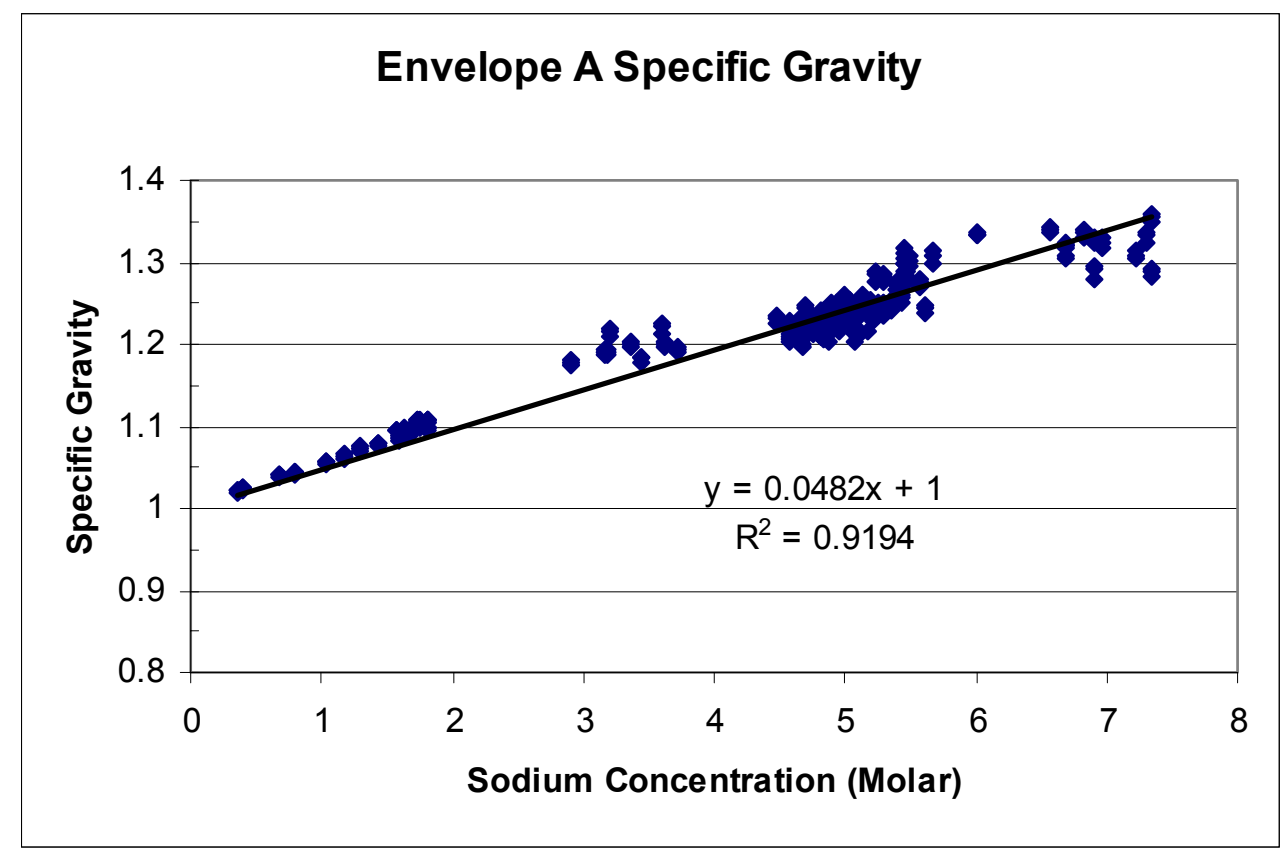

Figure C- 2. Envelope A Slurry Specific Gravity @ $25^{\circ} \mathrm{C}$ 


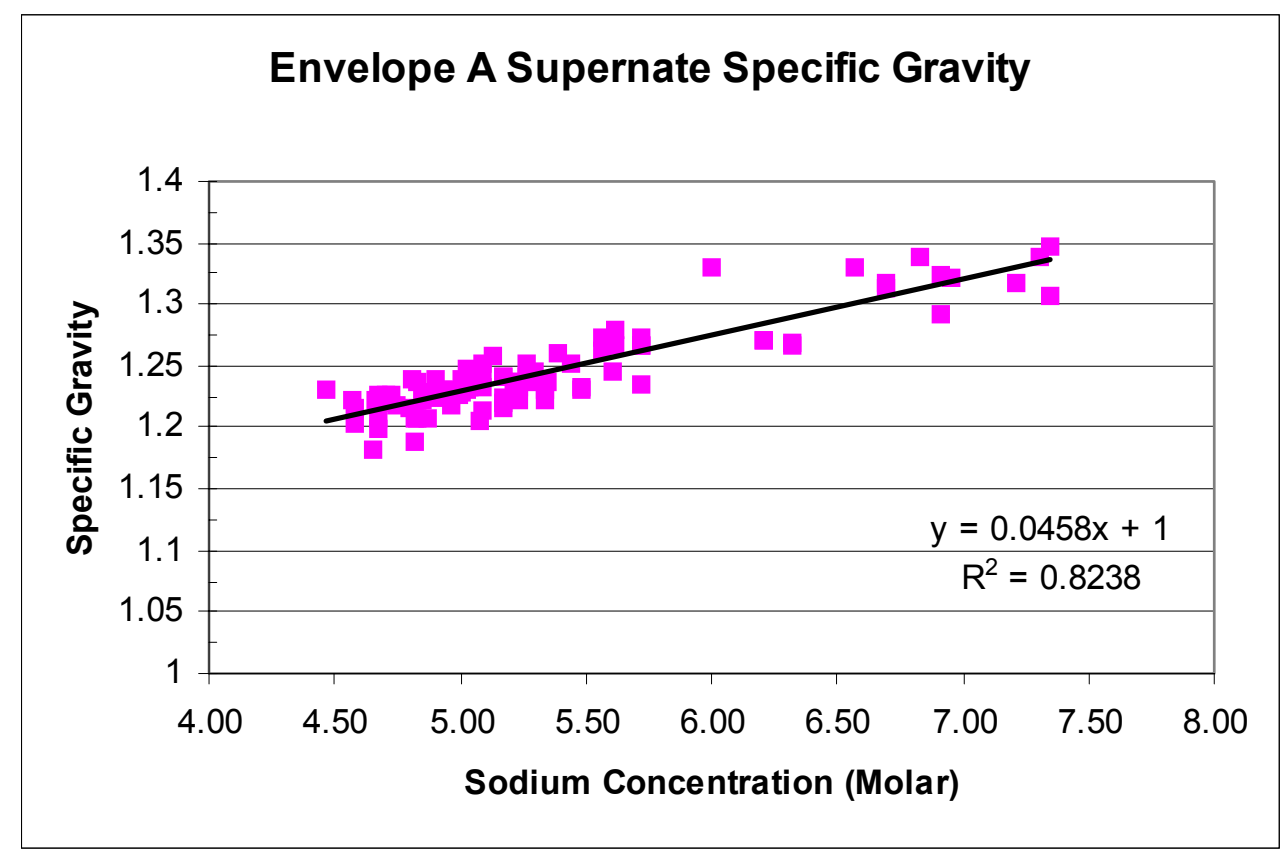

Figure C- 3. Envelope A Supernate Specific Gravity @ $25^{\circ} \mathrm{C}$

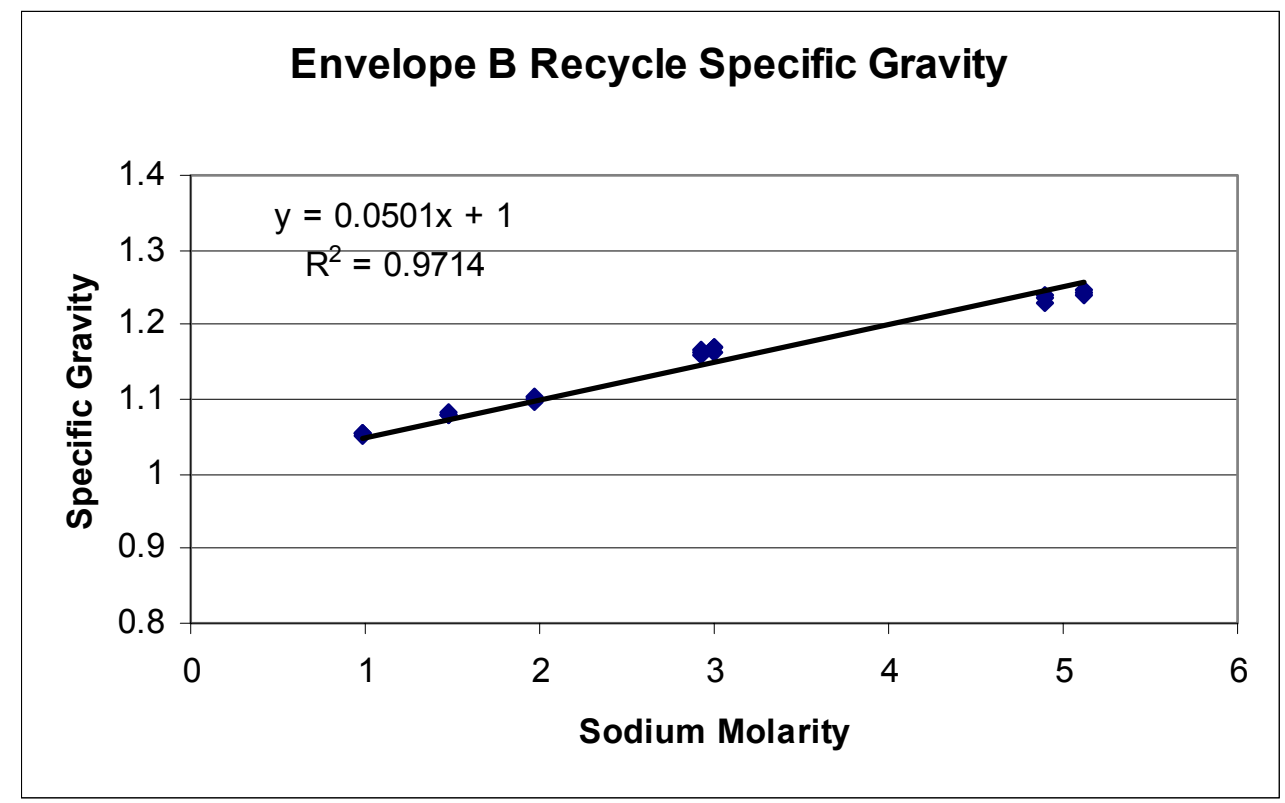

Figure C- 4. Envelope B Recycle Specific Gravity @ $25^{\circ} \mathrm{C}$ 


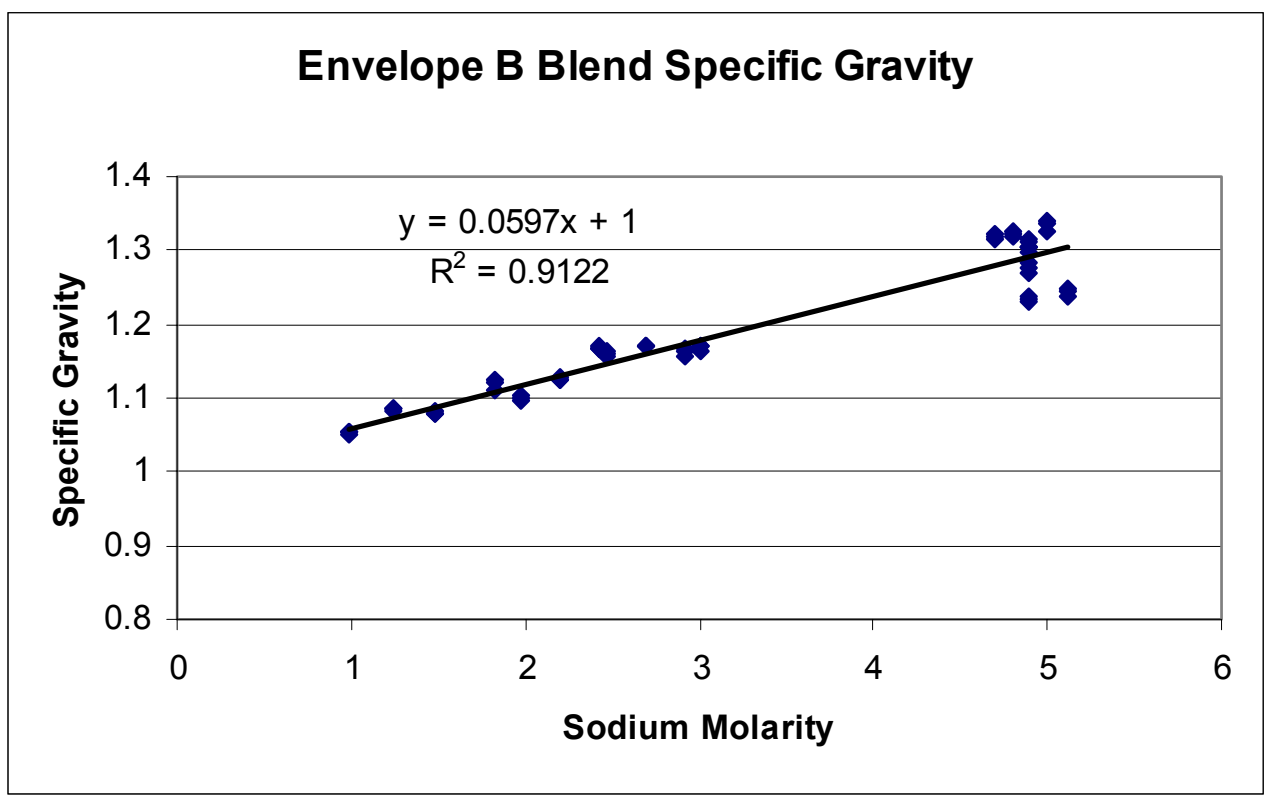

Figure C- 5. Envelope B Slurry Specific Gravity @ $25^{\circ} \mathrm{C}$

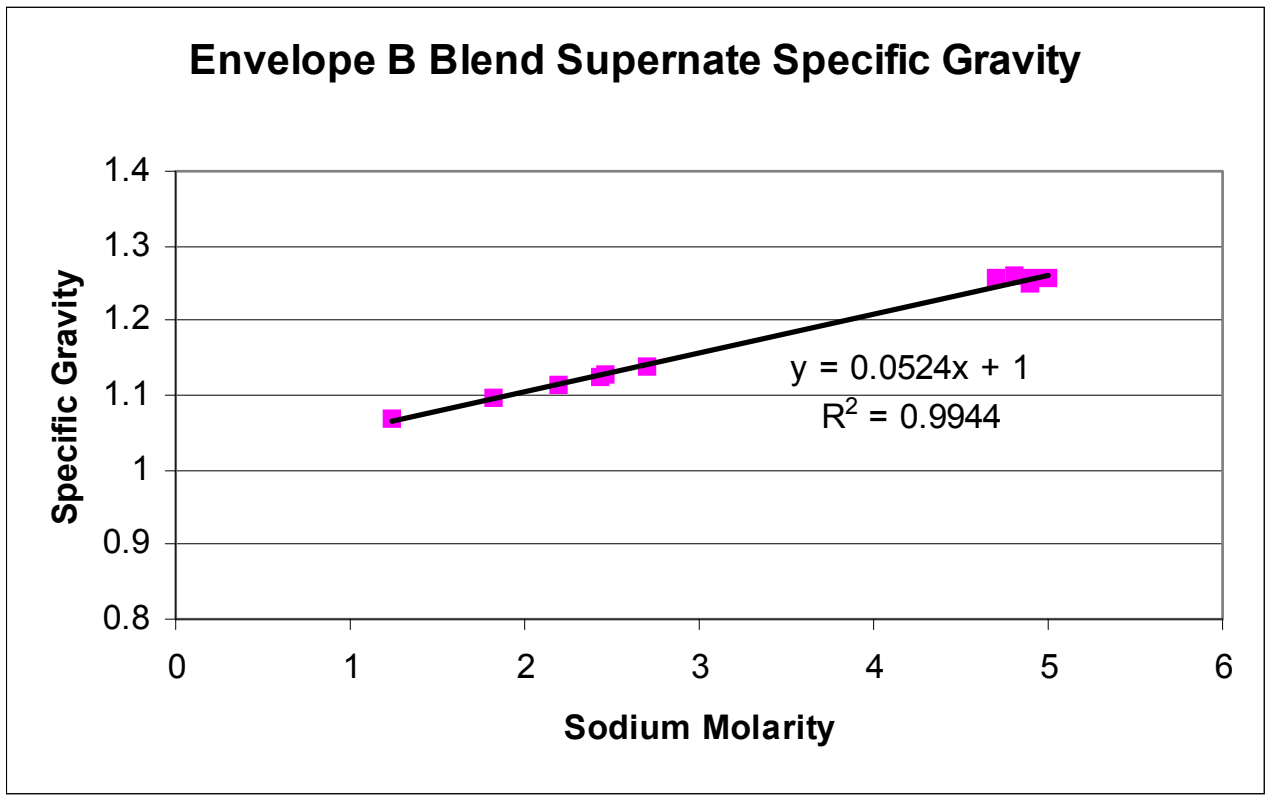

Figure C- 6. Envelope B Supernate Specific Gravity @ $25^{\circ} \mathrm{C}$ 


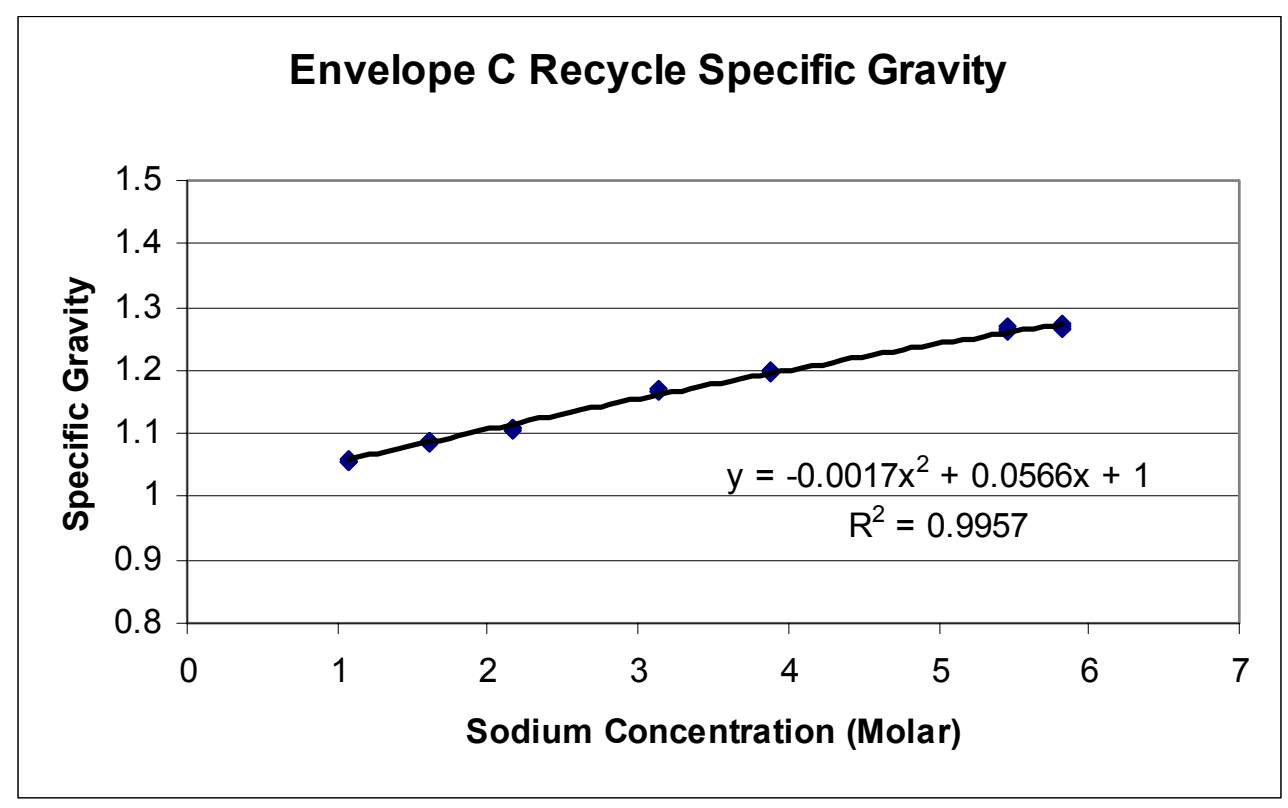

Figure C- 7. Envelope C Recycle Specific Gravity @ $25^{\circ} \mathrm{C}$

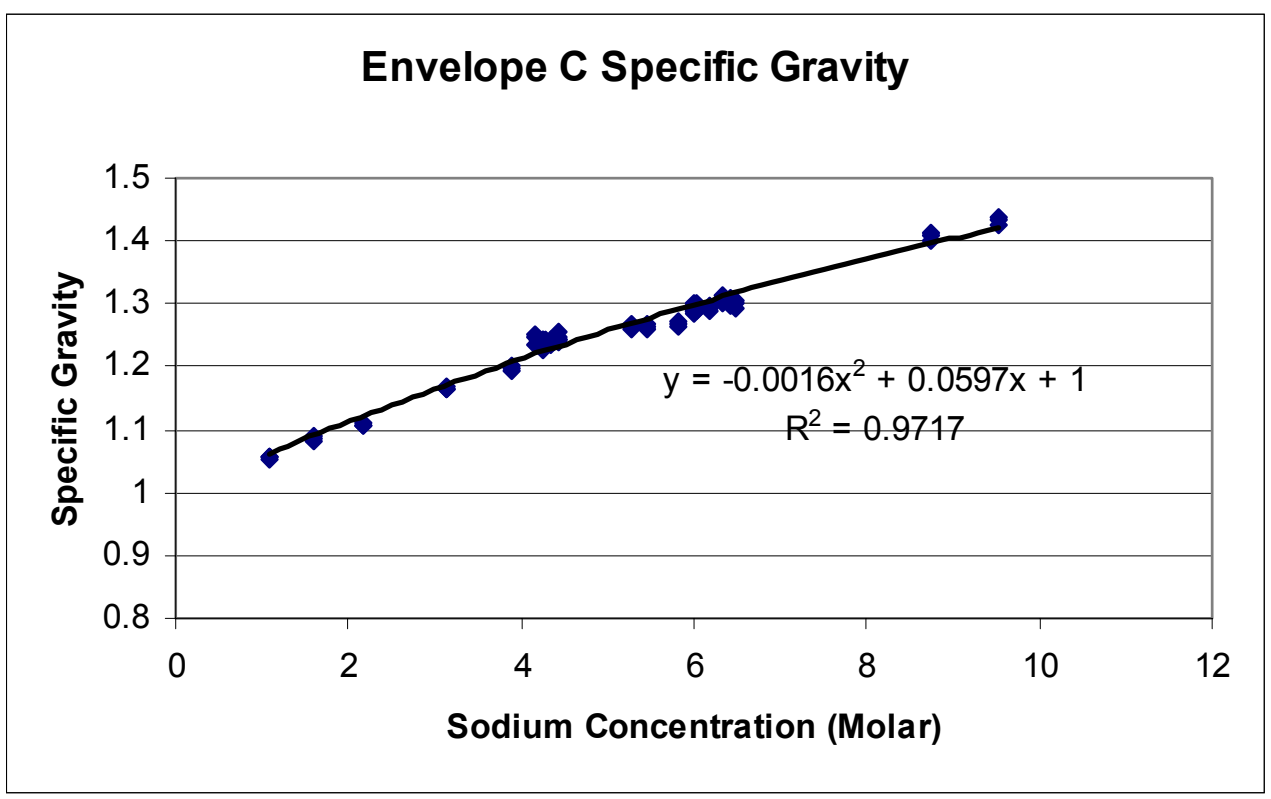

Figure C- 8. Envelope C Slurry Specific Gravity @ $25^{\circ} \mathrm{C}$ 


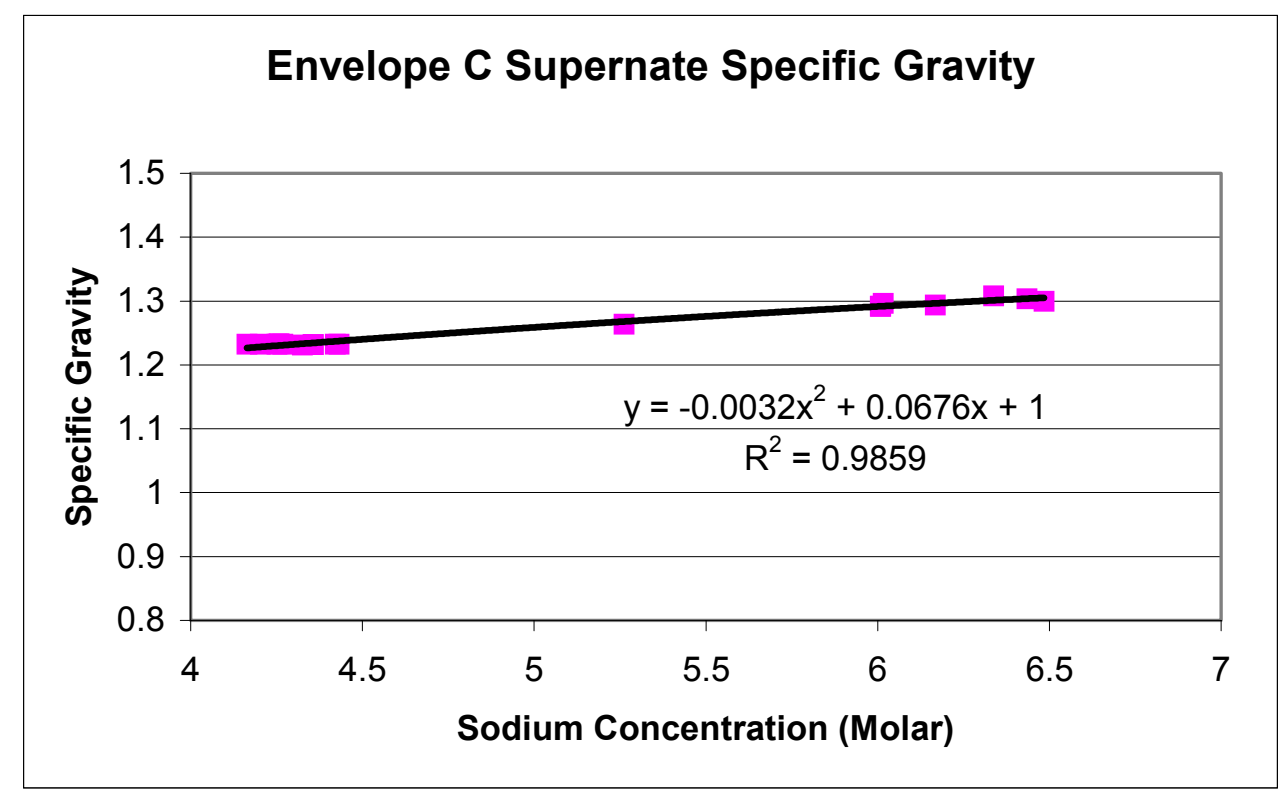

Figure C- 9. Envelope C Supernate Specific Gravity @ $25^{\circ} \mathrm{C}$ 

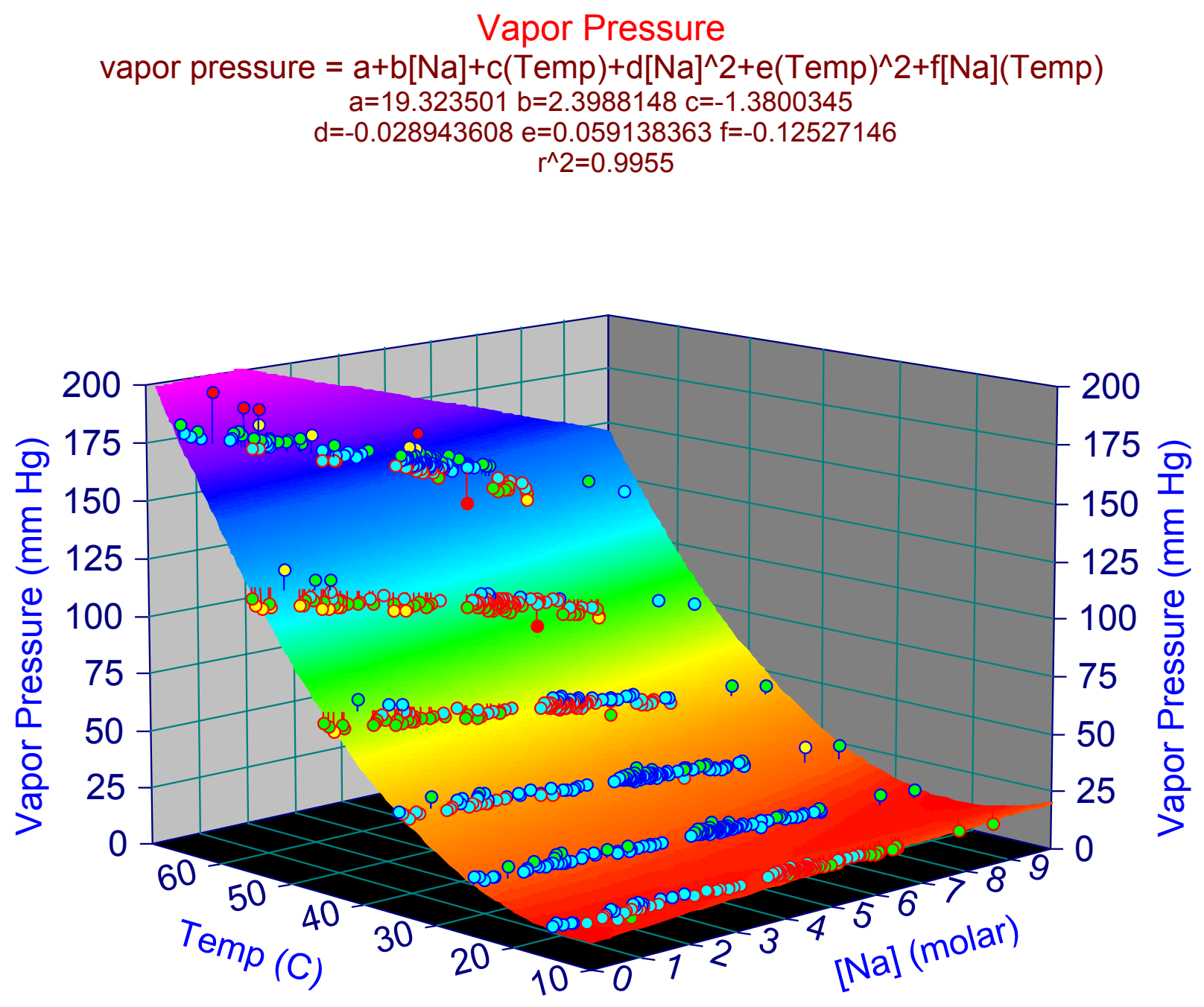

Figure C- 10. Vapor Pressure of All Samples 


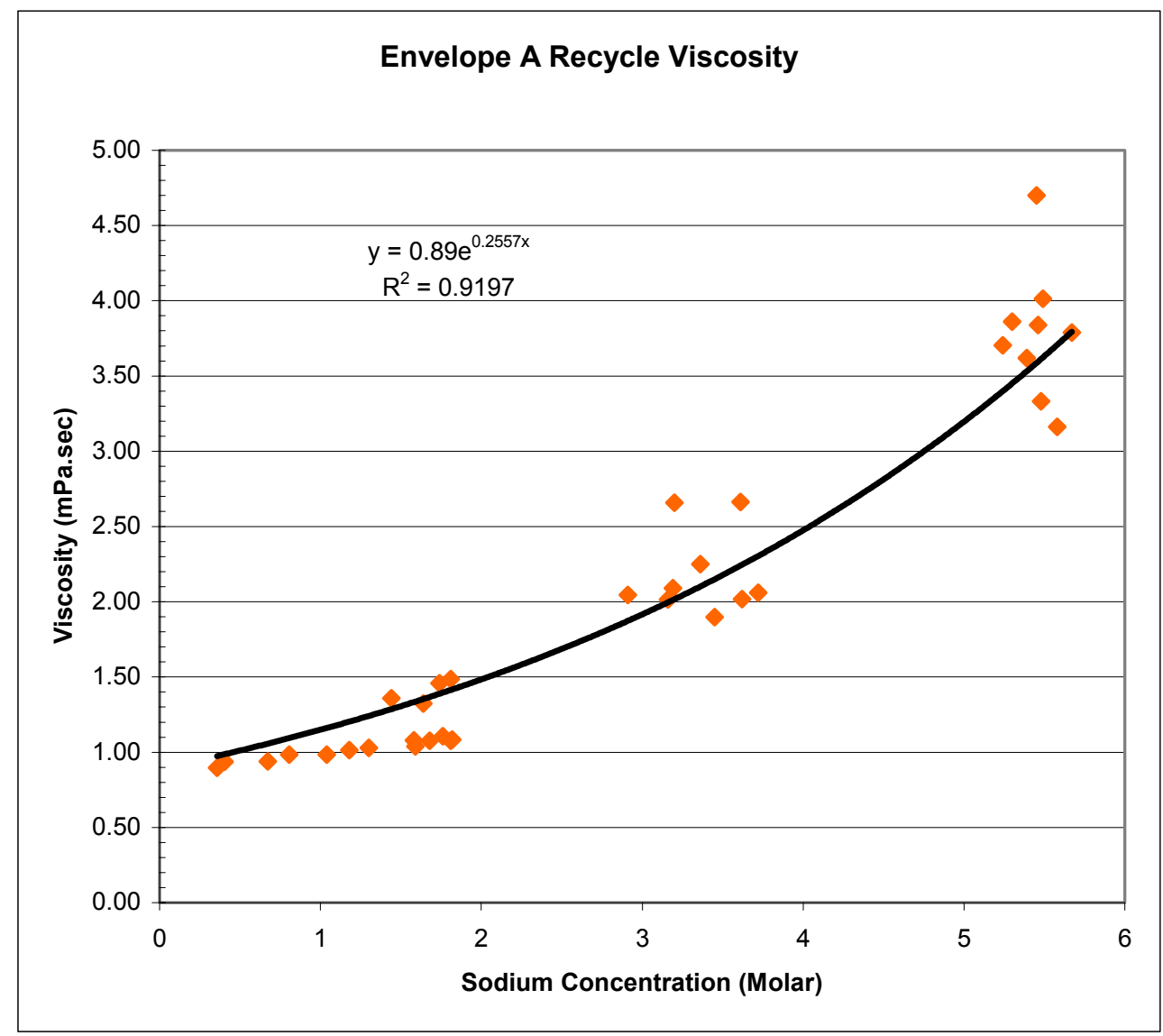

Figure C- 11. Envelope A Recycle Viscosity @ $25^{\circ} \mathrm{C}$

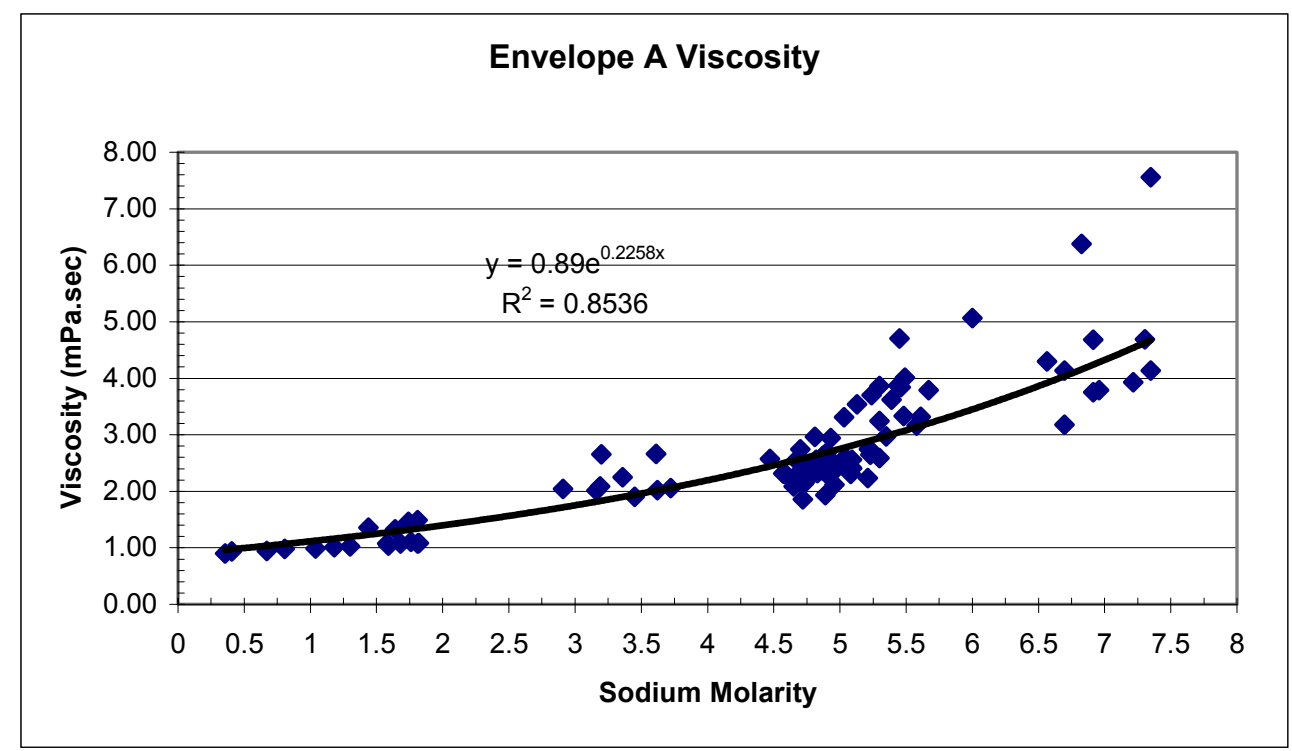

Figure C- 12. Envelope A Viscosity @ $25{ }^{\circ} \mathrm{C}$ 


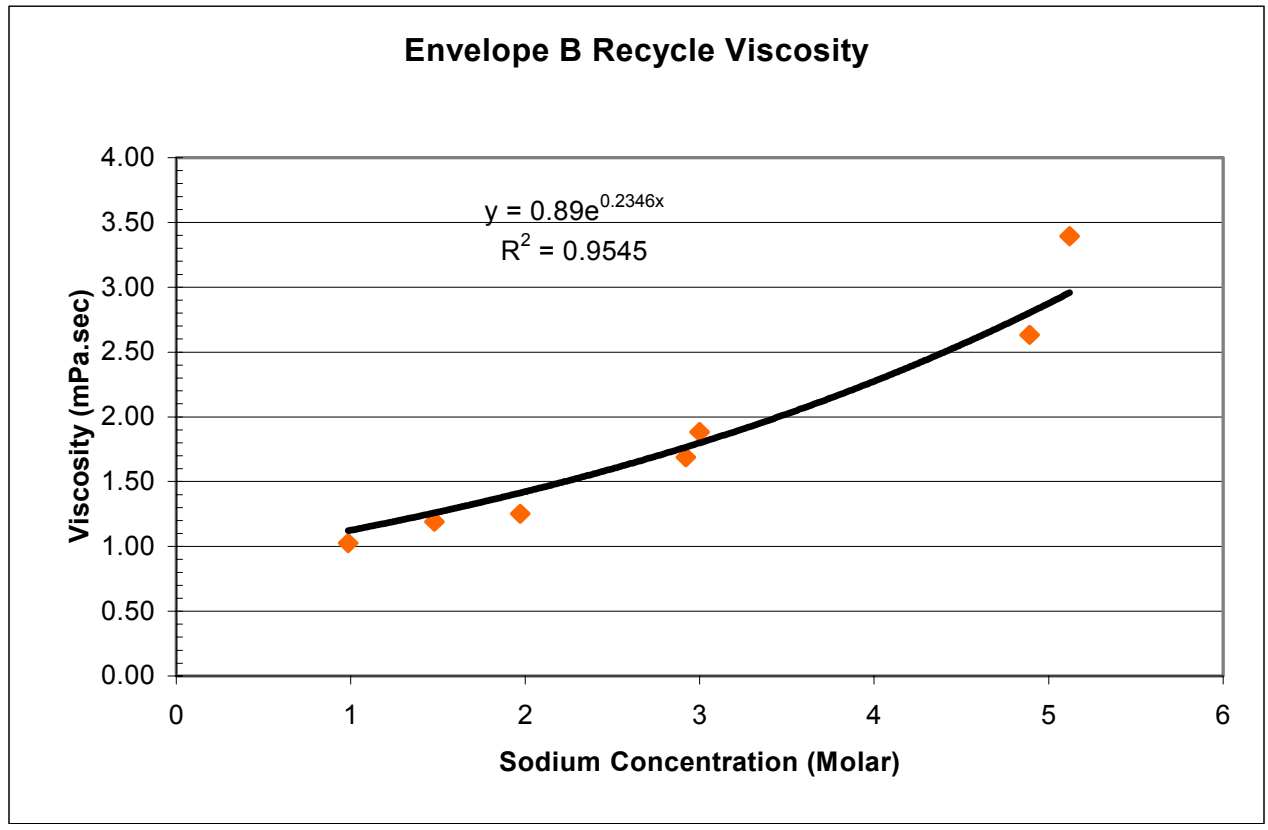

Figure C- 13. Envelope B Recycle Viscosity @ $25^{\circ} \mathrm{C}$.

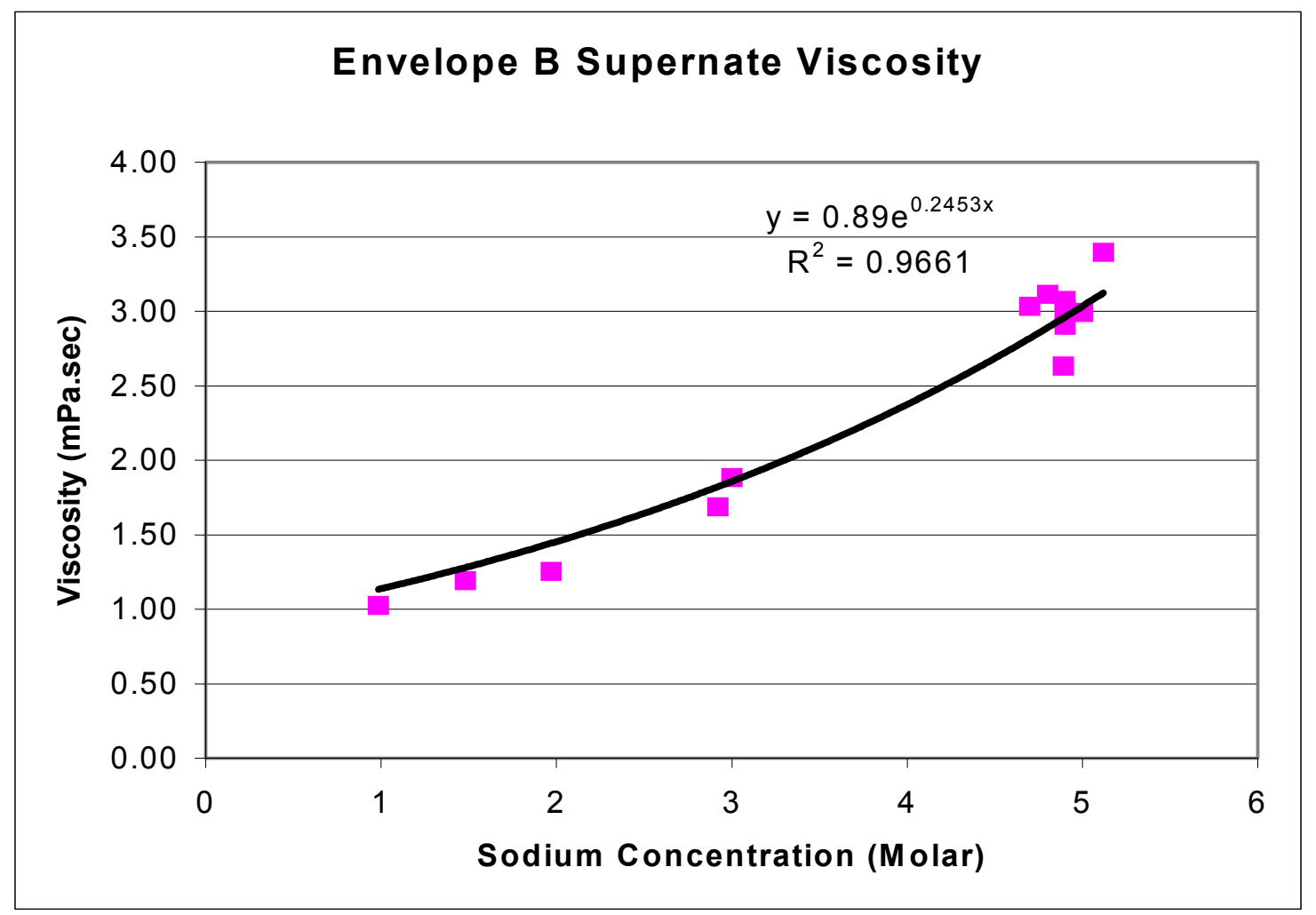

Figure C- 14. Envelope B Supernate Viscosity @ $25^{\circ} \mathrm{C}$ 


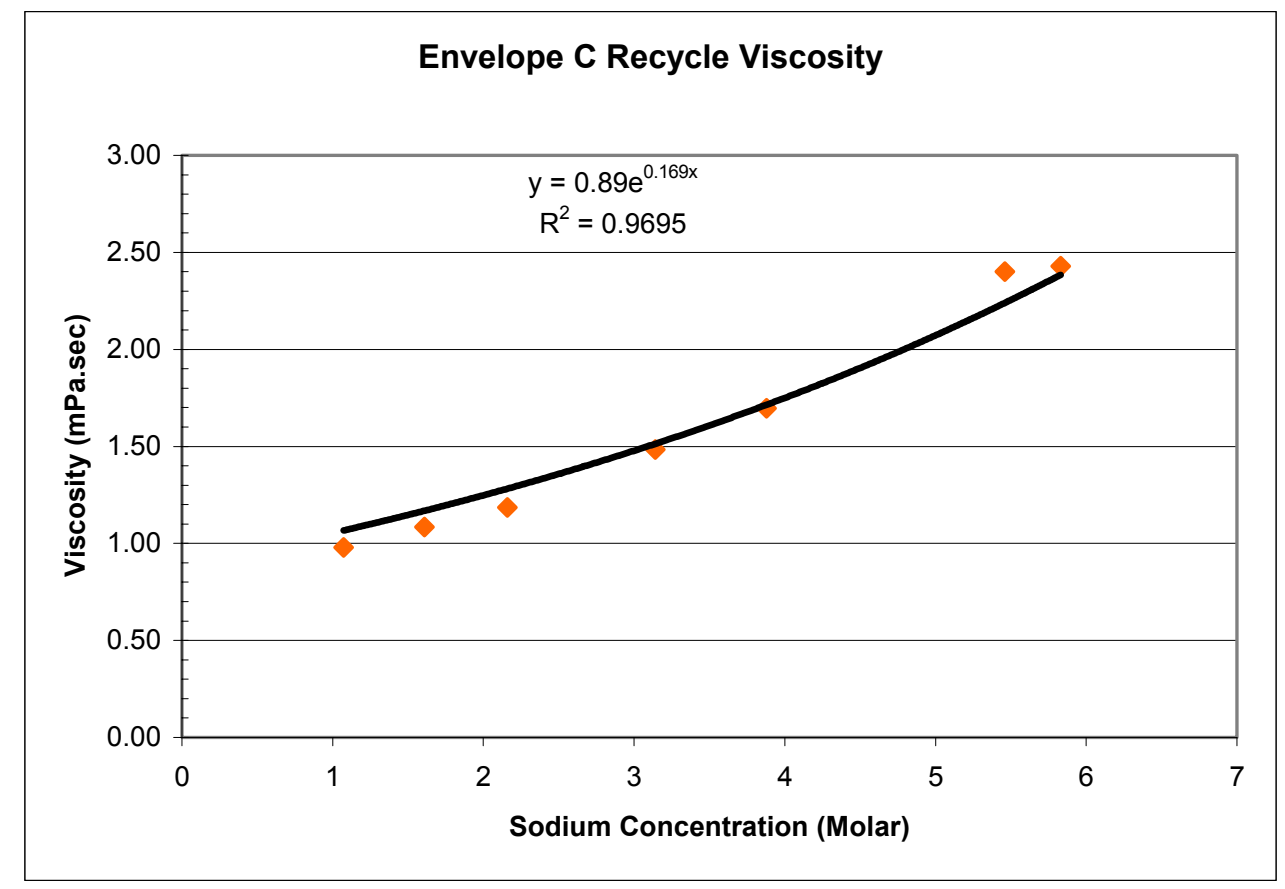

Figure C- 15. Envelope C Recycle Viscosity @ $25^{\circ} \mathrm{C}$

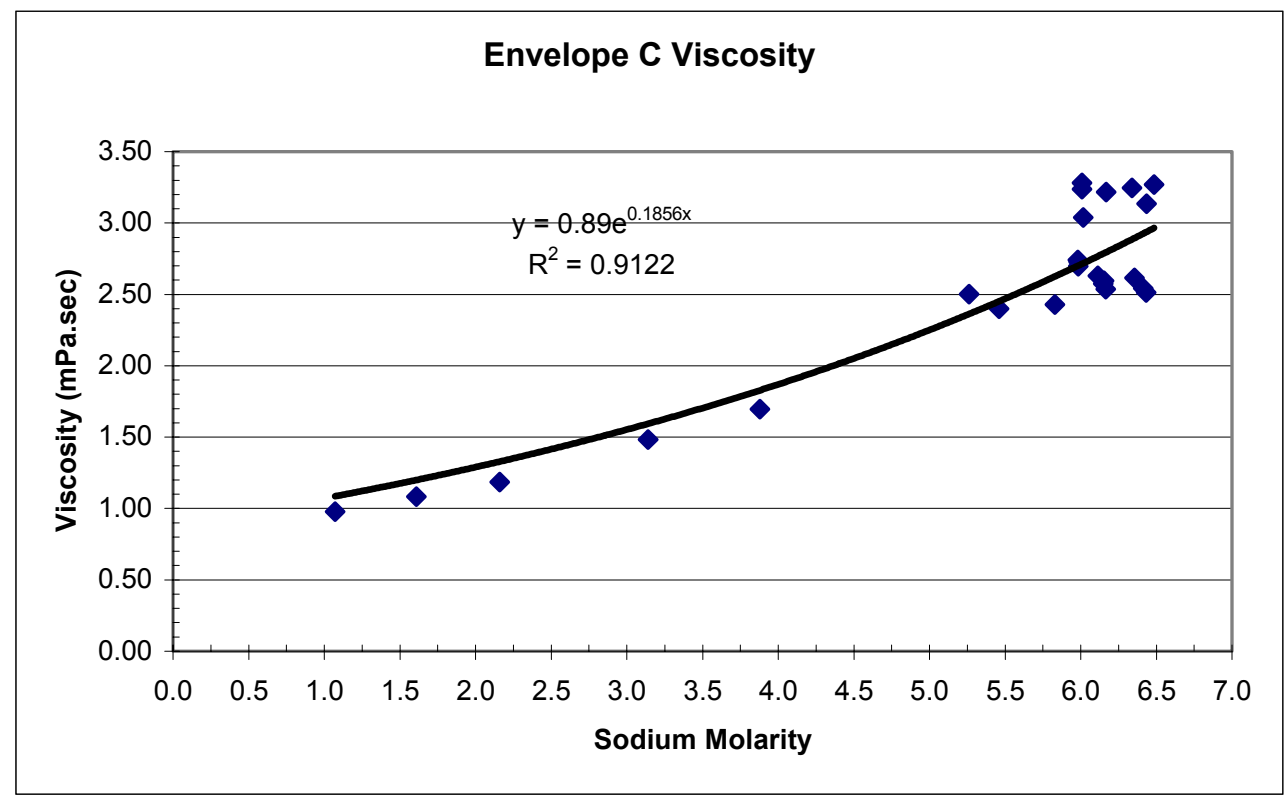

Figure C- 16. Envelope C Viscosity $@ 25^{\circ} \mathrm{C}$ 


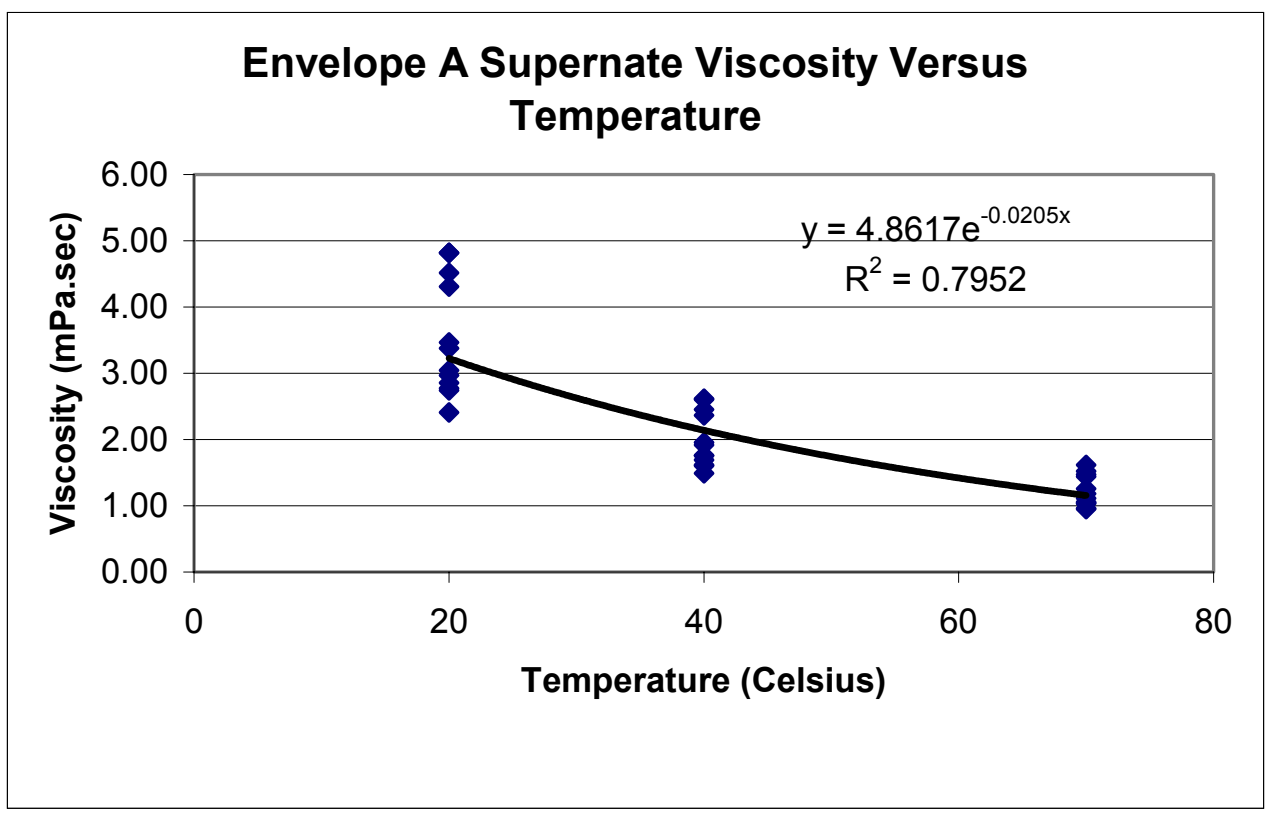

Figure C-17. Envelope A Viscosity as a Function of Temperature

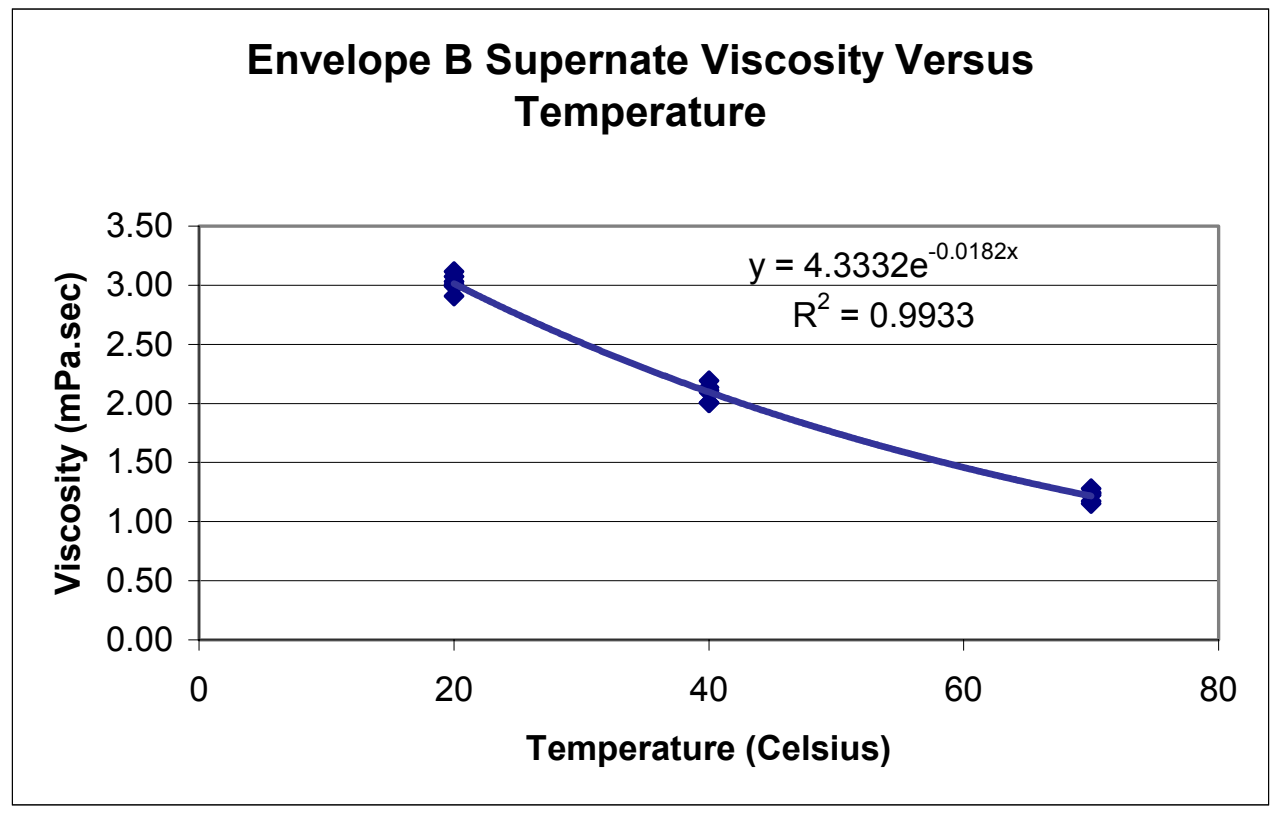

Figure C- 18. Envelope B Viscosity as a Function of Temperature 


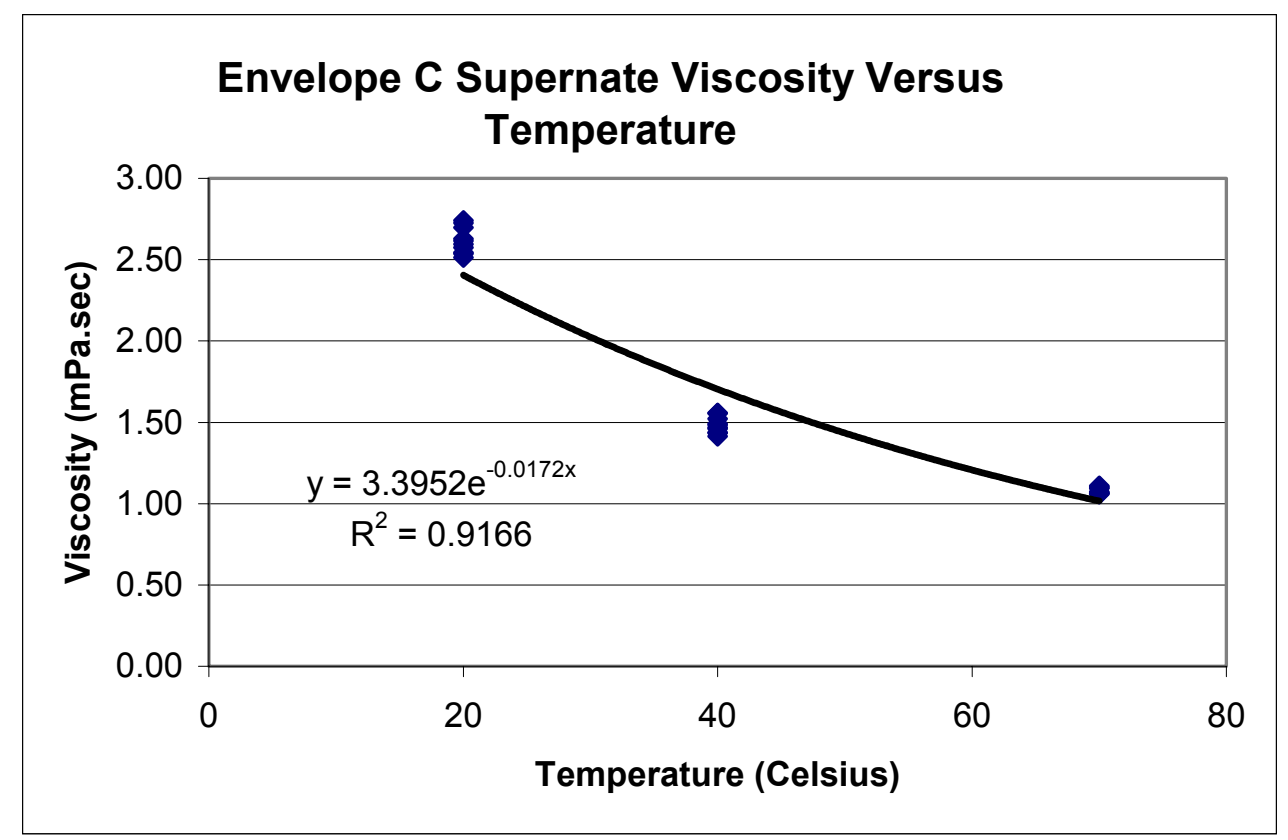

Figure C- 19. Envelope C Viscosity as a Function of Temperature 


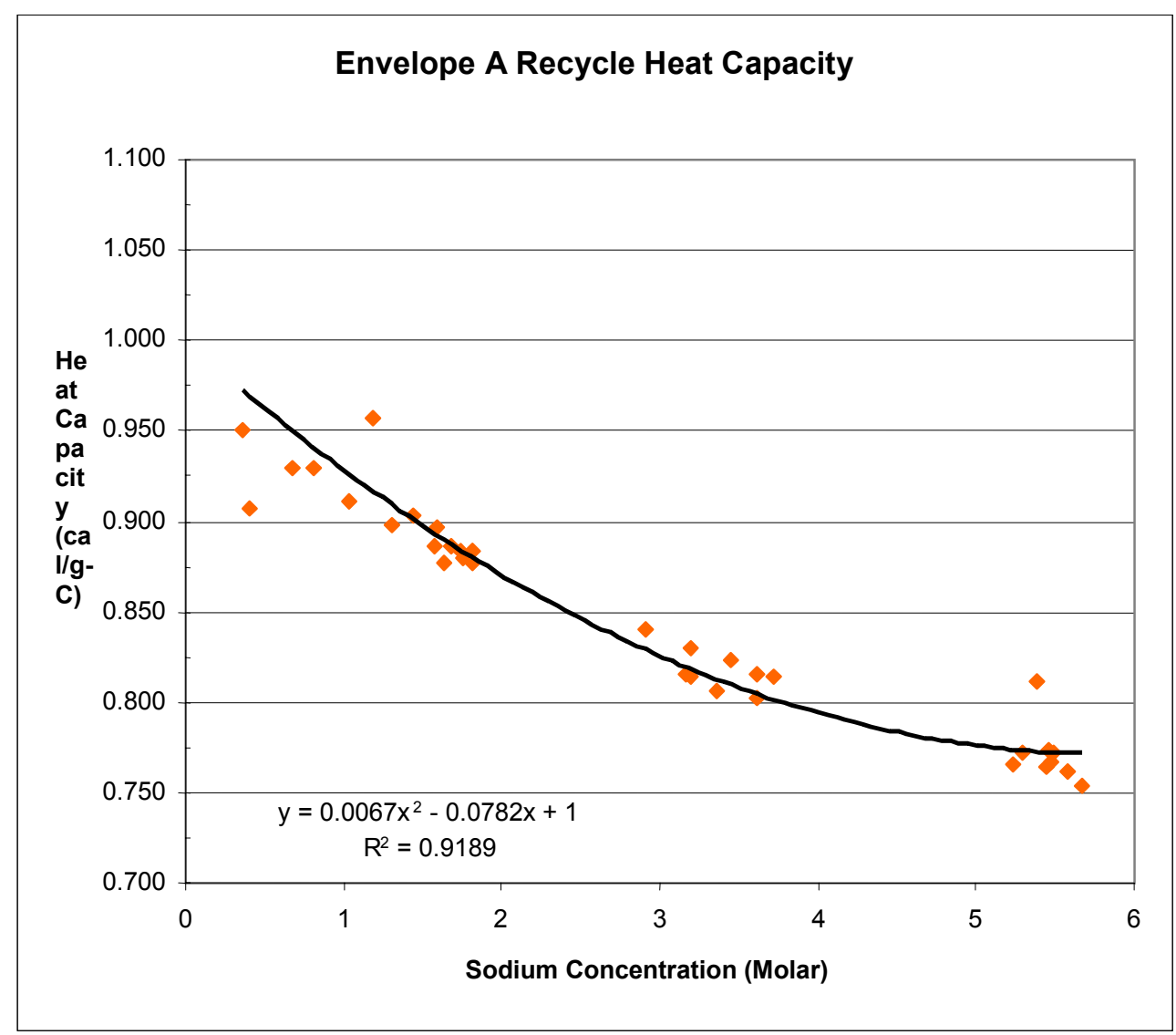

Figure C- 20. Envelope A Recycle Heat Capacity

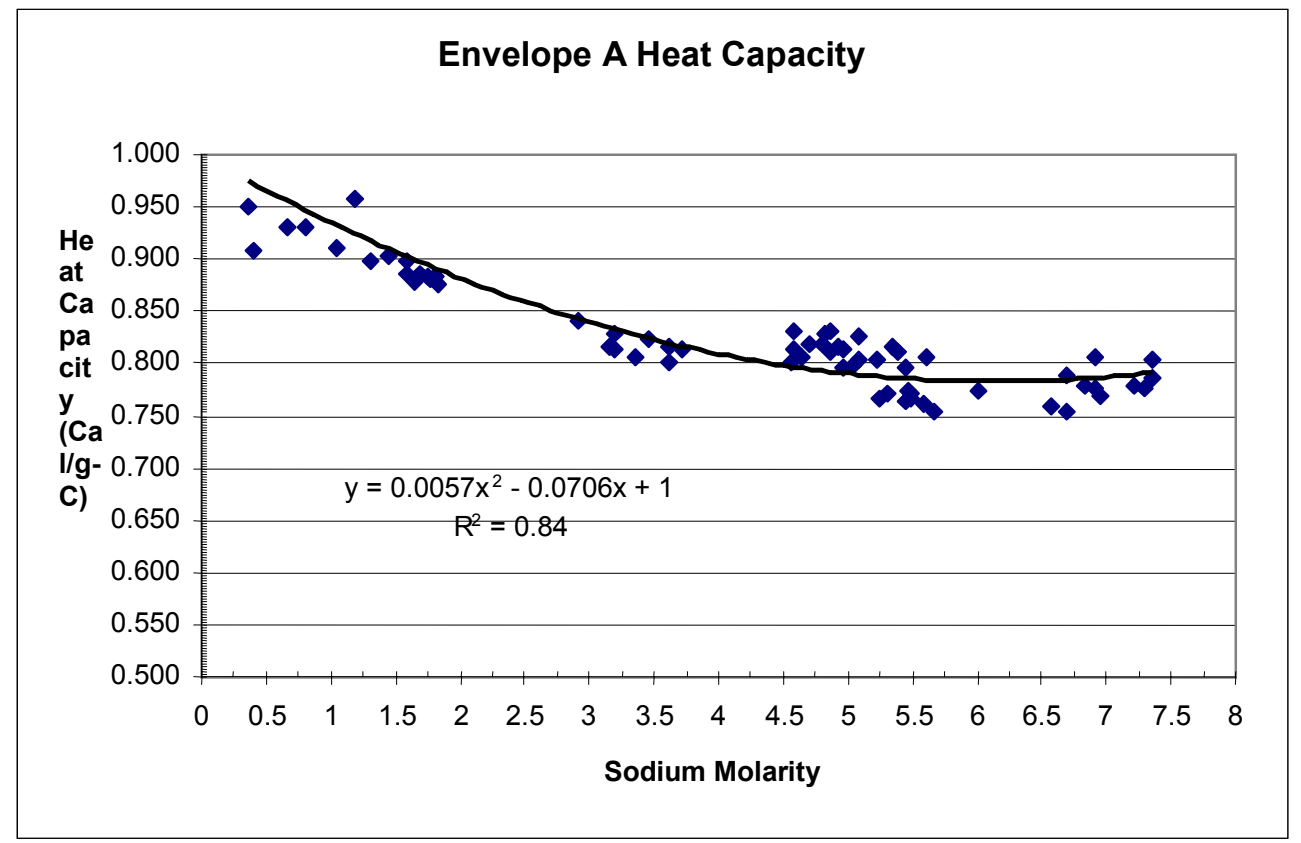

Figure C- 21. Envelope A Heat Capacity 


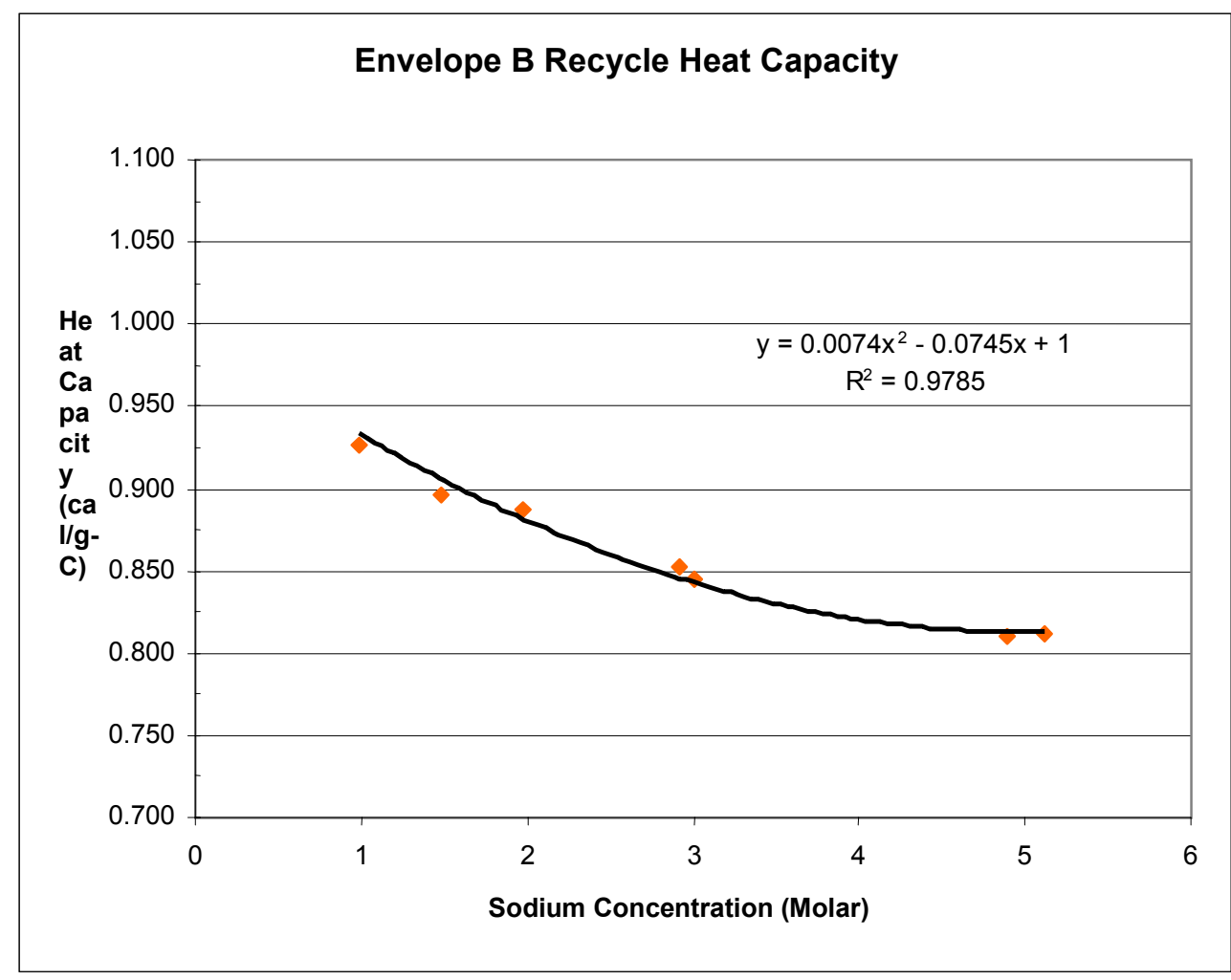

Figure C- 22. Envelope B Recycle Heat Capacity

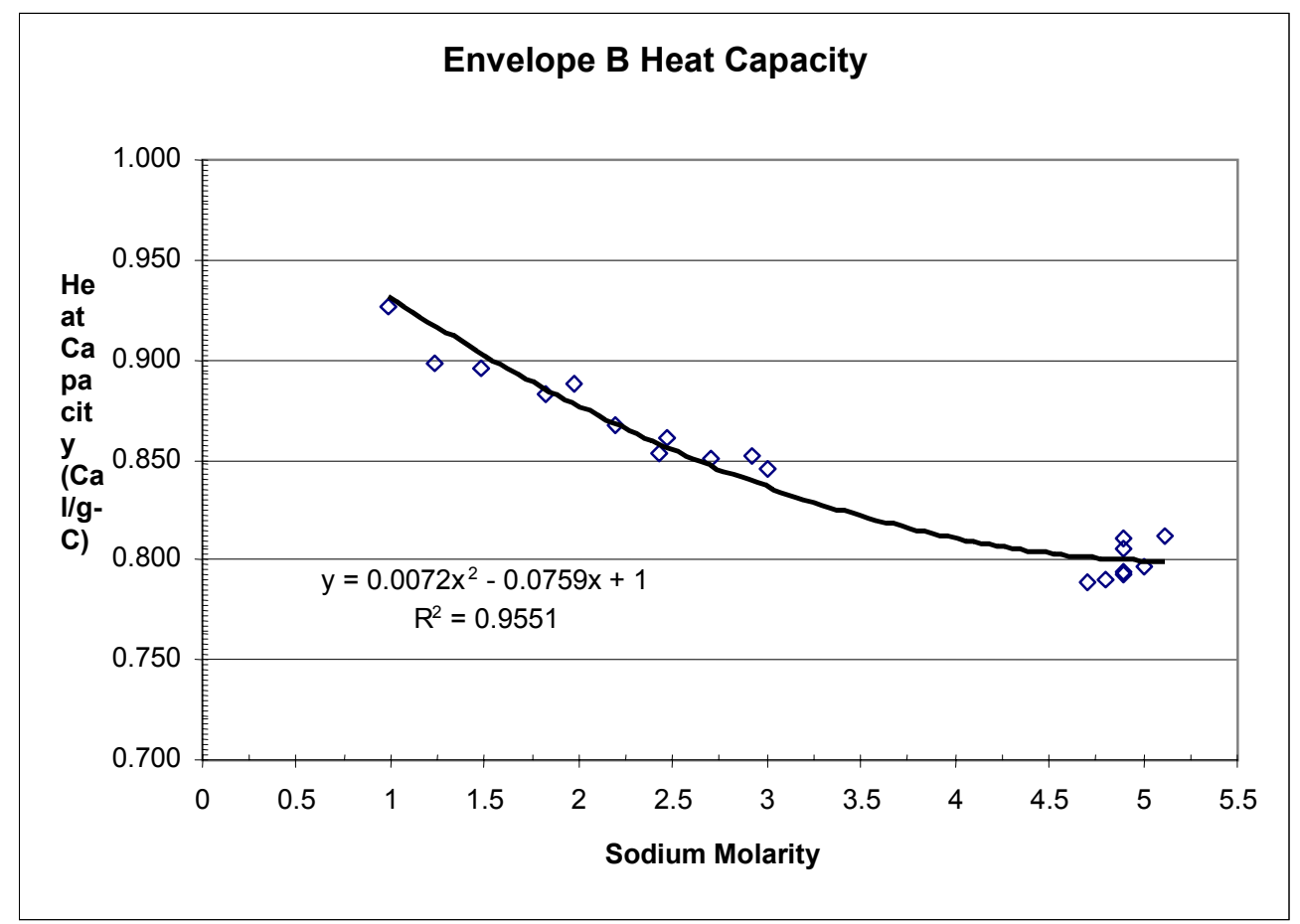

Figure C- 23. Envelope B Heat Capacity 


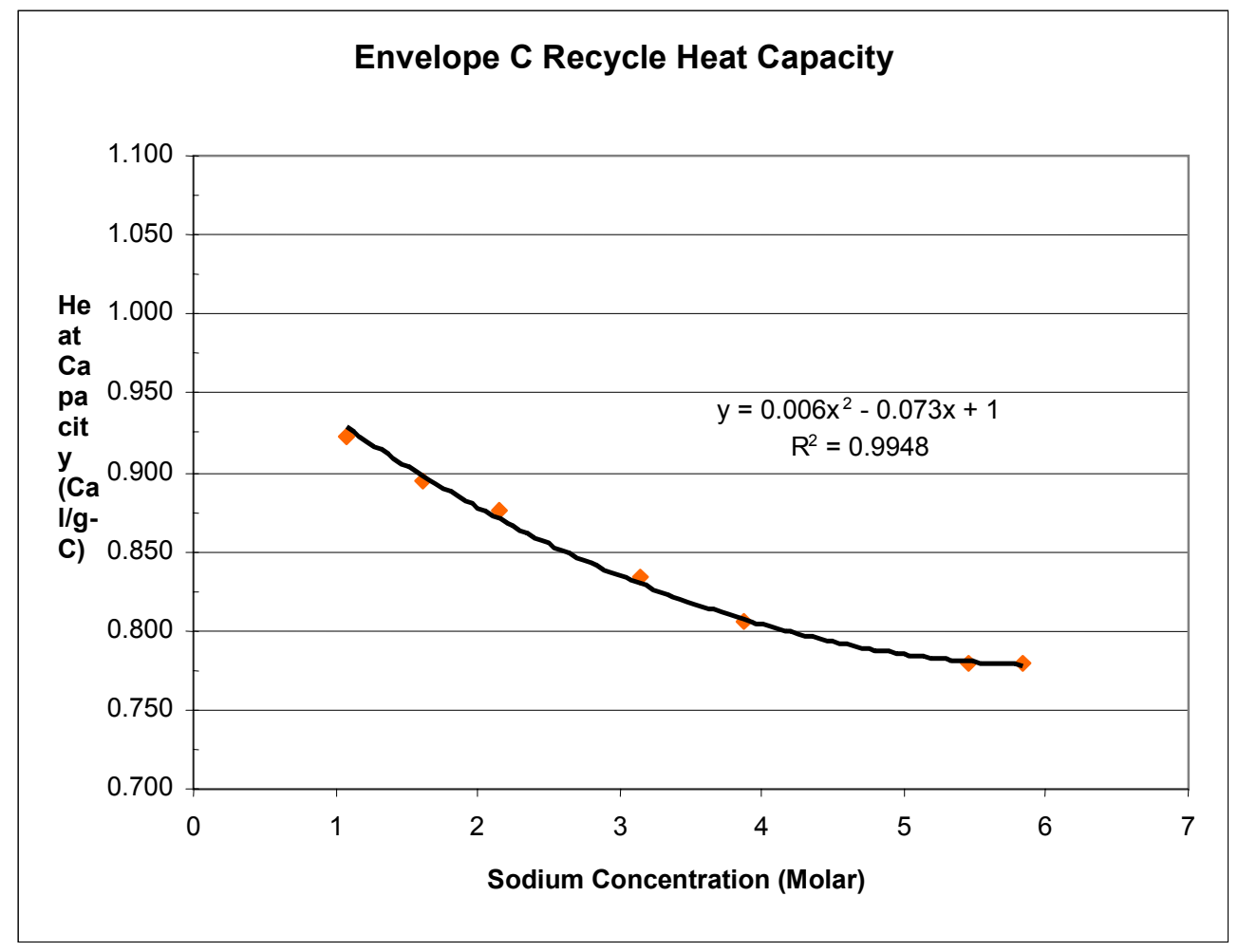

Figure C- 24. Envelope C Recycle Heat Capacity

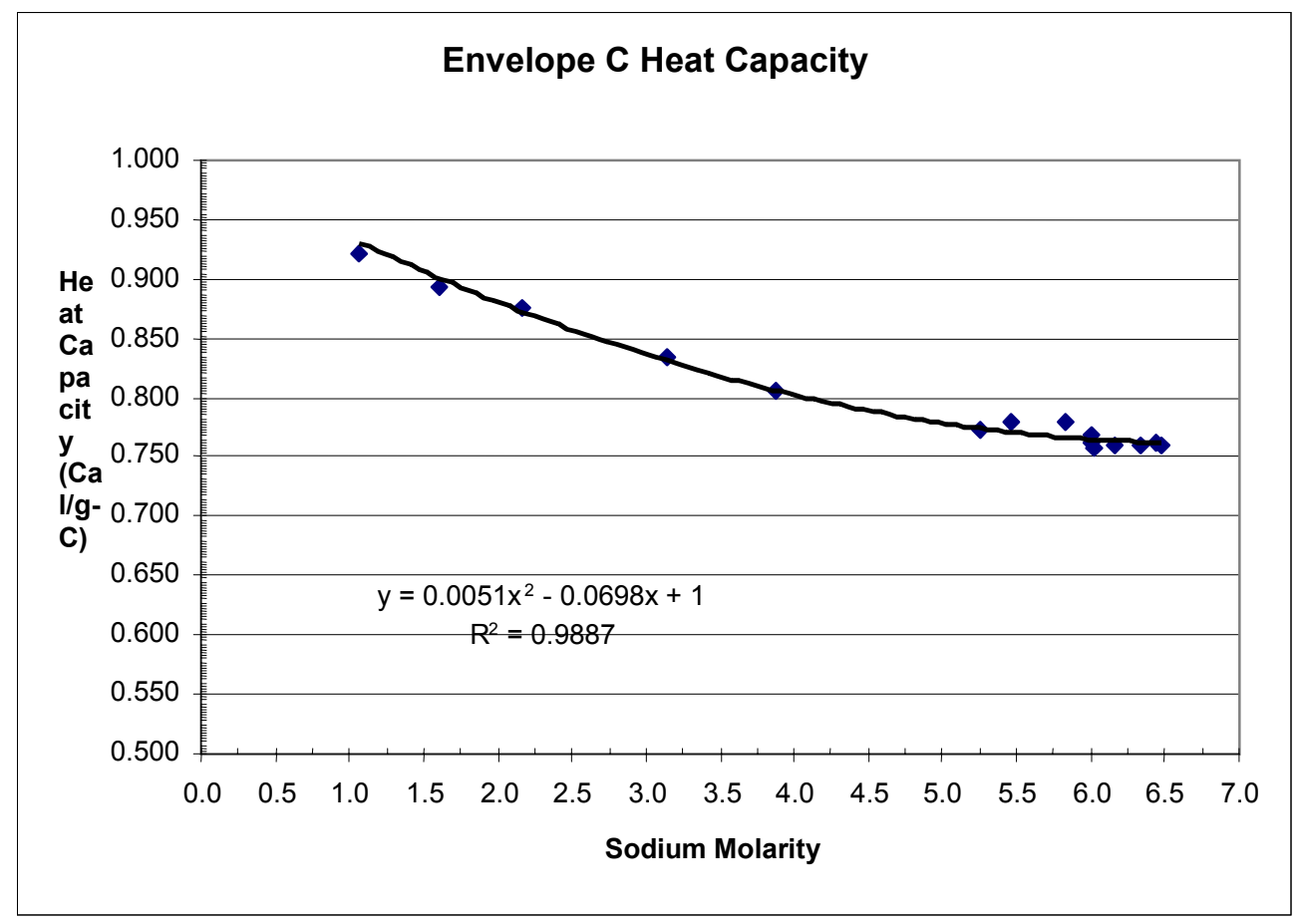

Figure C- 25. Envelope C Heat Capacity 


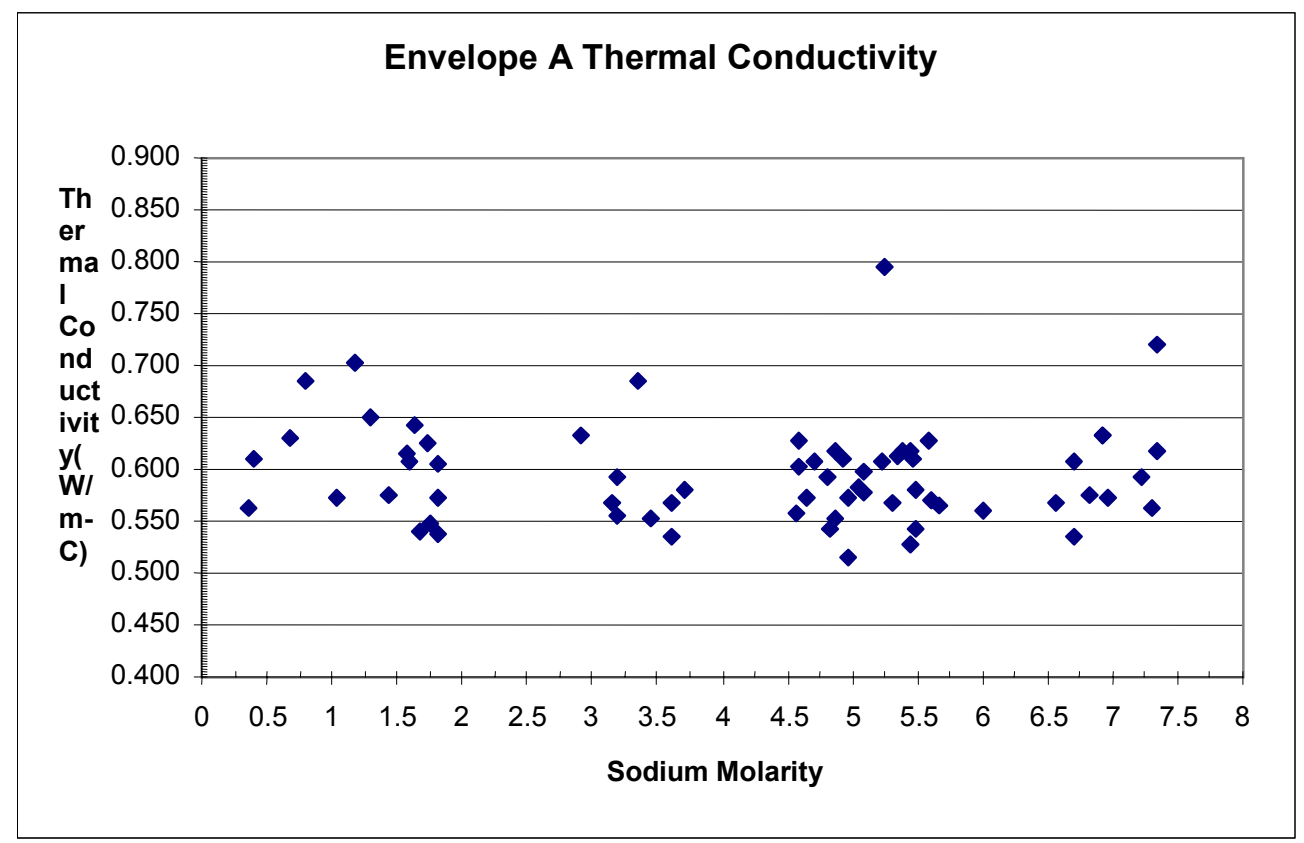

Figure C- 26. Envelope A Thermal Conductivity

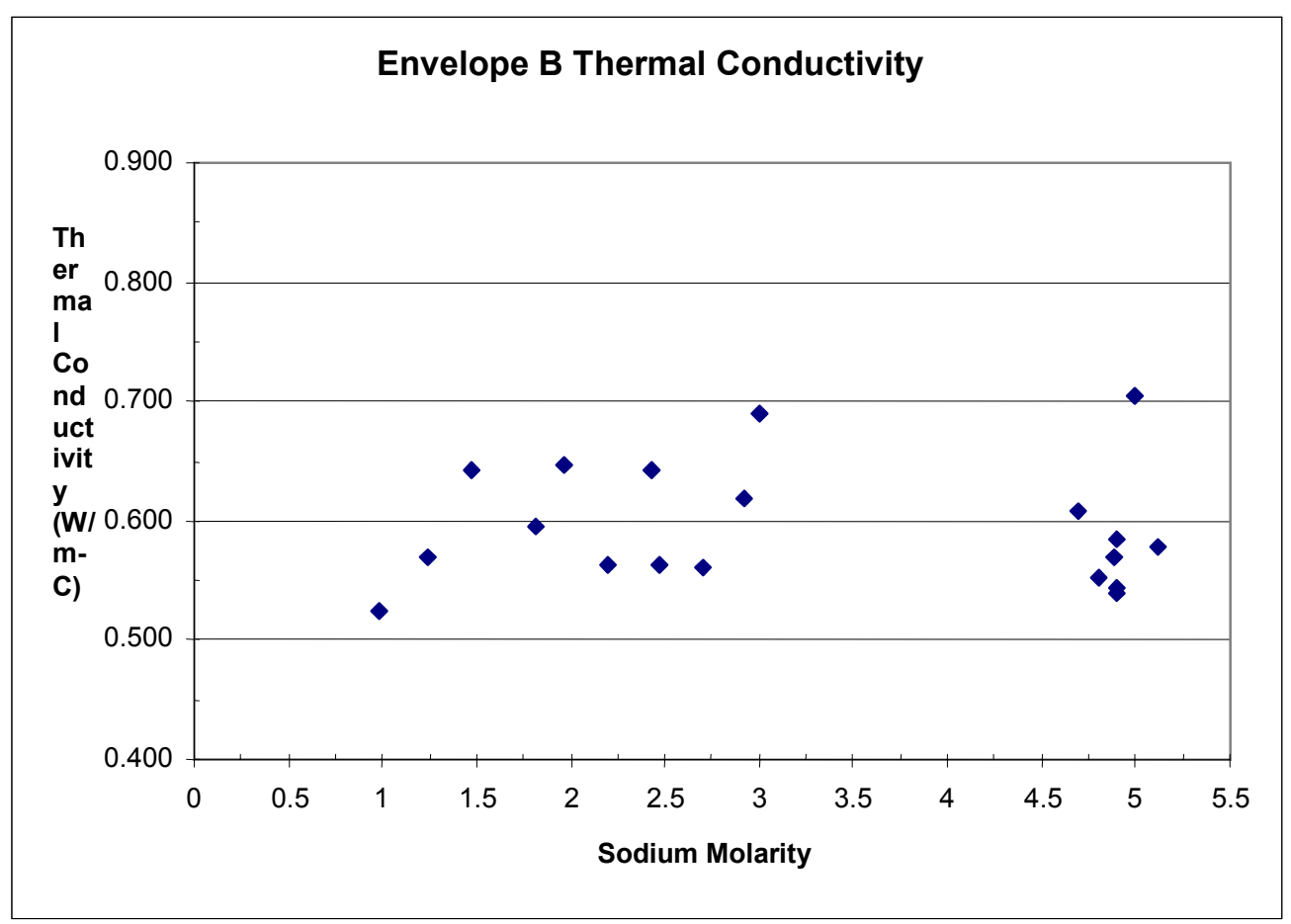

Figure C- 27. Envelope B Thermal Conductivity 


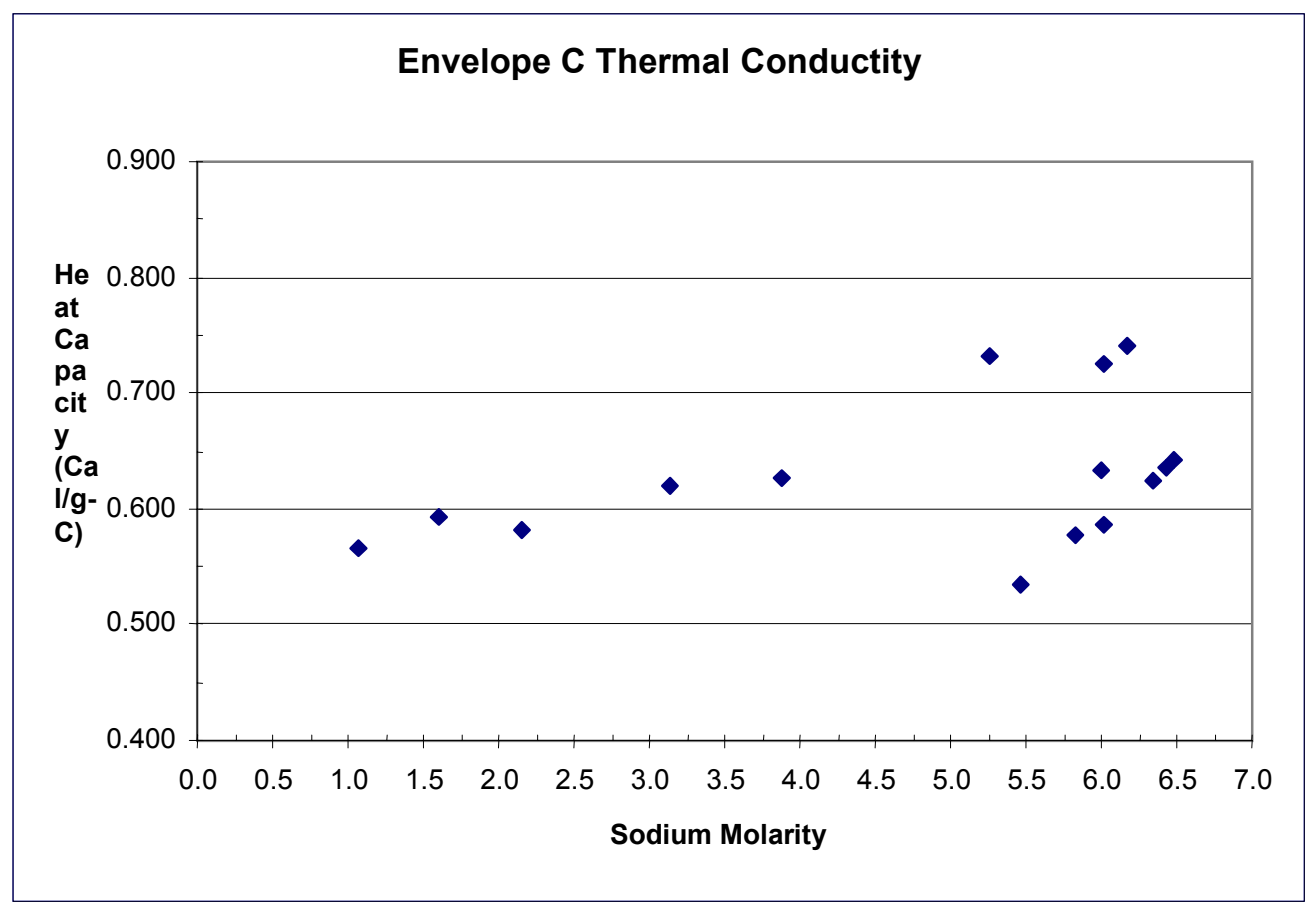

Figure C- 28. Envelope C Thermal Conductivity 


\section{Appendix D. Modeling of UF Blend Process}

An OLI model was developed to predict the $\mathrm{pH}$ of the blended ultrafiltration recycle stream. The model included the $1^{\text {st }}$ and $2^{\text {nd }}$ wash, leach solution, $0.1 \mathrm{M}$ caustic rinse from the cleaning cycle, and the $2 \mathrm{M}$ nitric acid cleaning solution. The model was executed using the compositions and volume ratios from the SRTC waste feed evaporation study for validation. Since validation failed, the model was not utilized to perform experimental work or evaluate the UF recycle process.

The objectives of the process model were:

* Input the UF recycle stream compositions provided by Process Engineering into OLI and charge balance.

* Determine the $\mathrm{pH}$ of the blended UF recycles.

* Determine the amount of caustic required to adjust the $\mathrm{pH}$ of the ultrafiltration recycle to $\mathrm{pH} 10,11$, and 12 .

\section{D - 1.0 Charge Balance of Input Streams}

The streams for the leach option were input into an Excel ${ }^{\circledR}$ spreadsheet and charge balanced by addition of aluminum nitrate in place of sodium aluminate. Addition of the aluminum nitrate allowed the charges to be balanced, but aluminum nitrate is not stable in basic solutions and consumes hydroxide to become sodium aluminate. This reaction lowers the $\mathrm{pH}$ of the solution, but since OLI predicted a $\mathrm{pH}$ above 12 for the UF blend stream for this option, the charge balance was deemed acceptable. Sodium was not used for the charge balance due to the large amount required to balance the charge. The large discrepancy in charge balance was reviewed with WTP personnel. It is assumed that the large discrepancy in charge balance is the result of the leach factors used in the Aspen model not being charge balanced.

The streams for the no leach option were charge balanced by the addition of sodium. For UFP44, the sodium was $0.28 \mathrm{M}$ above target to account for the charge discrepancy and the difference was $0.13 \mathrm{M}$ for UFP39.

The compositions of the balanced streams are shown in Table D-1, along with the compositions used by SRTC for the evaporation study. UFP44 corresponds to the first wash in the SRTC study and UFP39 is the $2^{\text {nd }}$ wash and Leach combined. The SRTC composition for the acid cleaning solution was used during all runs and the $0.1 \mathrm{M}$ caustic rinse composition was the same from the WTP compositions as well as the SRTC study.

Table D- 1. Charge Balanced Input Streams

\begin{tabular}{|c|c|c|c|c|c|c|c|c|c|}
\hline & \multicolumn{2}{|c|}{ Leach Option } & \multicolumn{2}{|c|}{ No Leach Option } & \multicolumn{5}{|c|}{ SRTC Evaporator Study Compositions } \\
\hline & UFP44 & UFP39 & UFP44 & UFP39 & $\begin{array}{l}1^{\text {st }} \\
\text { wash }\end{array}$ & $\begin{array}{l}2^{\text {nd }} \\
\text { Wash }\end{array}$ & Leach & $\begin{array}{l}\text { Acid } \\
\text { Clean }\end{array}$ & $\begin{array}{l}0.1 \mathrm{M} \\
\text { Caustic }\end{array}$ \\
\hline & $\mathrm{Wt} \%$ & $\mathrm{Wt} \%$ & $\mathrm{Wt} \%$ & $\mathrm{Wt} \%$ & Wt \% & Wt $\%$ & $\mathrm{Wt} \%$ & $\mathrm{Wt} \%$ & $\mathrm{Wt} \%$ \\
\hline $\mathrm{Na}_{2} \mathrm{OAl}_{2} \mathrm{O}_{3}$ & 0.9504 & 3.37 & 1.53 & 0.779 & 1.81 & 1.43 & 2.83 & - & - \\
\hline $\mathrm{Al}\left(\mathrm{NO}_{3}\right)_{3}$ & 1.9318 & 0.97 & - & - & - & - & - & - & - \\
\hline $\mathrm{Na}_{2} \mathrm{~B}_{4} \mathrm{O}_{7}$ & 0.0077 & 0.0025 & 0.0097 & 0.0050 & - & - & - & - & - \\
\hline $\mathrm{Ca}\left(\mathrm{NO}_{3}\right)_{2}$ & 0.0324 & 0.037 & 0.0275 & 0.014 & - & - & - & - & - \\
\hline $\mathrm{Cd}\left(\mathrm{NO}_{3}\right)_{2}$ & $1.8 \mathrm{E}-4$ & $5.9 \mathrm{E}-5$ & $1.6 \mathrm{E}-4$ & $8.4 \mathrm{E}-5$ & - & - & - & - & - \\
\hline
\end{tabular}




\begin{tabular}{|c|c|c|c|c|c|c|c|c|c|}
\hline $\mathrm{NaCl}$ & 0.130 & 0.042 & 0.168 & 0.086 & - & - & - & - & - \\
\hline $\mathrm{Na}_{2} \mathrm{CO}_{3}$ & 2.459 & 0.802 & 2.321 & 1.18 & 1.84 & 0.290 & 0.71 & - & - \\
\hline $\mathrm{Cr}\left(\mathrm{NO}_{3}\right)_{3}$ & 0.2182 & 0.203 & 0.2055 & 0.105 & - & - & - & - & - \\
\hline $\mathrm{NaF}$ & 0.325 & 0.110 & 0.2394 & 0.122 & 0.239 & - & - & - & - \\
\hline $\mathrm{Fe}\left(\mathrm{NO}_{3}\right)_{3}$ & 0.060 & 0.118 & 0.043 & 0.022 & - & - & - & 0.285 & - \\
\hline $\mathrm{KNO}_{3}$ & 0.4097 & 0.1558 & 0.593 & 0.302 & - & - & - & - & - \\
\hline $\mathrm{Mg}\left(\mathrm{NO}_{3}\right)_{2}$ & 0.0020 & $6.4 \mathrm{E}-4$ & 0.0019 & $9.5 \mathrm{E}-4$ & - & - & - & 0.015 & - \\
\hline $\mathrm{Mn}\left(\mathrm{NO}_{3}\right)_{2}$ & 0.0036 & 0.0232 & $6 \mathrm{E}-4$ & $3.1 \mathrm{E}-4$ & - & - & - & 0.015 & - \\
\hline $\mathrm{Ni}\left(\mathrm{NO}_{3}\right)_{2}$ & 0.0195 & 0.0262 & 0.0186 & 0.0133 & - & - & - & 0.045 & - \\
\hline $\mathrm{NaNO}_{2}$ & 2.33 & 0.7606 & 2.873 & 1.45 & 3.82 & 0.020 & 0.060 & - & - \\
\hline $\mathrm{NaNO}_{3}$ & 3.25 & 0 & 4.95 & 2.52 & 6.01 & 0.010 & 0.020 & 0.135 & - \\
\hline $\mathrm{NaOH}$ & 3.42 & 5.47 & 3.36 & 1.72 & 4.77 & 2.41 & 6.32 & - & 0.04 \\
\hline $\mathrm{Na}_{3} \mathrm{PO}_{4}$ & 0.617 & 0.261 & 0.5034 & 0.257 & 0.210 & 0.030 & 0.030 & - & - \\
\hline $\mathrm{NaHSiO}_{3}$ & 0.1897 & 0.2075 & 0.156 & 0.0789 & - & - & - & - & - \\
\hline $\mathrm{Na}_{2} \mathrm{SO}_{4}$ & 0.222 & 0.0786 & 0.223 & 0.1135 & 0.210 & 0.020 & 0.030 & - & - \\
\hline $\mathrm{Sr}\left(\mathrm{NO}_{3}\right)_{2}$ & $9.5 \mathrm{E}-4$ & 0.0023 & $6 \mathrm{E}-4$ & $3.1 \mathrm{E}-4$ & - & - & - & - & - \\
\hline $\mathrm{Zn}\left(\mathrm{NO}_{3}\right)_{2}$ & $2.7 \mathrm{E}-4$ & $9.3 \mathrm{E}-4$ & $2 \mathrm{E}-4$ & $1.0 \mathrm{E}-4$ & - & - & - & - & - \\
\hline $\mathrm{SiO} 2$ & - & - & - & - & 0.0200 & 0.010 & 0.020 & 0.015 & - \\
\hline $\mathrm{Al}(\mathrm{OH})_{3}$ & - & - & - & - & - & - & - & 0.255 & - \\
\hline $\mathrm{ZrO}_{2}$ & - & - & - & - & - & - & - & 0.045 & - \\
\hline $\mathrm{HNO}_{3}$ & - & - & - & - & - & - & - & 11.26 & - \\
\hline $\mathrm{H}_{2} \mathrm{O}$ & 83.42 & 87.36 & 82.78 & 91.21 & 80.93 & 95.78 & 89.98 & 87.93 & 99.96 \\
\hline
\end{tabular}

\section{D - 2.0 Model Development}

A process model was developed with the process steps shown in Figure D-1. The model calculates equilibrium conditions for each step utilizing a user defined chemistry model. The chemistry model utilized for the UF blend model was the same chemistry model used for the evaporation modeling task.

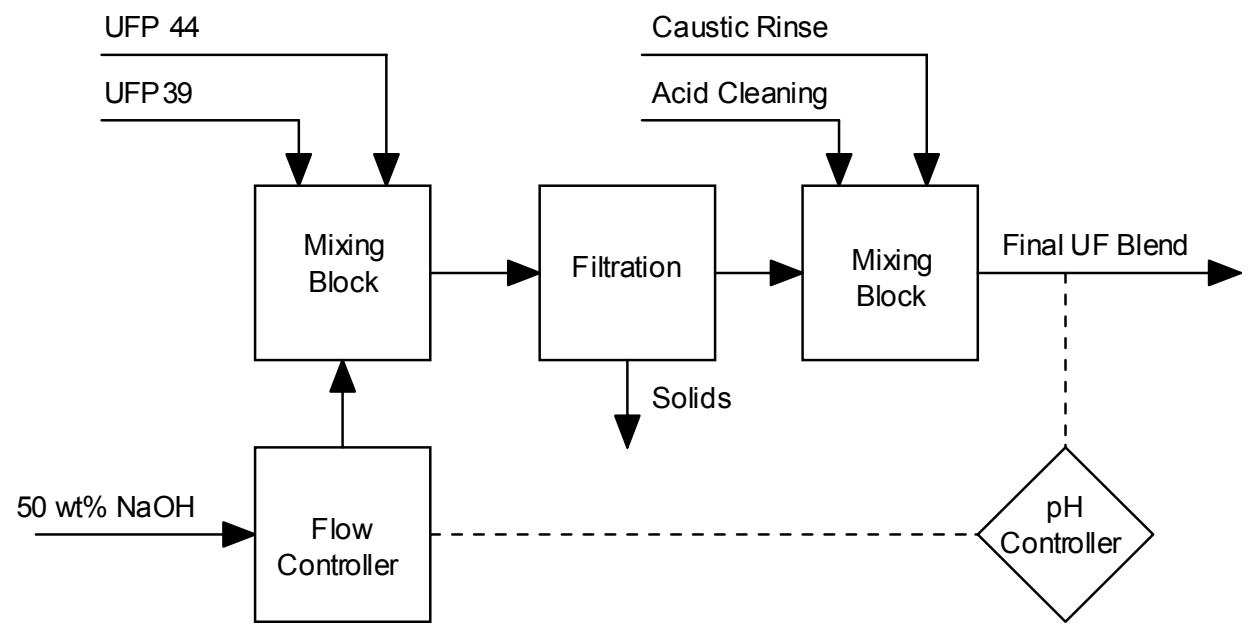

Figure D- 1. Block Diagram of UF Blend Model 


\section{D - 3.0 Validation}

An assessment of the validity of the OLI model was conducted. Tests were conducted during the evaporation experimental study that varied the amount of acid cleaning solution added to the $1^{\text {st }}$ and $2^{\text {nd }}$ wash. The $\mathrm{pH}$, free hydroxide, and soluble/insoluble Al of UF blend solutions from the evaporation experimental study were measured and compared to OLI runs using the same compositions and volume ratios.

Significant differences between the model prediction of $\mathrm{pH}$ and free hydroxide and the experimental results were noted, as shown in Table D-2 and Figure D-2. The OLI prediction was non-conservative as it predicted a higher $\mathrm{pH}$ than the experimental results. Similar results were noted in previous studies. ${ }^{14}$ Measurement of $\mathrm{pH}$ was conducted with an ion-selective solid state $\mathrm{pH}$ probe as well as narrow range $\mathrm{pH}$ paper during the model validation. In addition, the free hydroxide measurement was used to calculate $\mathrm{pH}$. Results from all three methods agreed with each other for most test solutions, therefore the measured $\mathrm{pH}$ was deemed to be accurate.

Conversations with the vendor for the OLI software indicated that the $\mathrm{pH}$ predictions by OLI have not been previously validated since very few customers measure $\mathrm{pH}$. Based on the discepancies noted, the model prediction of $\mathrm{pH}$ was judged to be inaccurate. Adjustment of the model with a private database is possible, but this option has not been explored.

Table D- 2. pH Results

\begin{tabular}{|c|c|c|c|c|c|c|c|c|c|c|}
\cline { 3 - 11 } \multicolumn{2}{c|}{} & \multicolumn{4}{c|}{ Measured Values } & \multicolumn{6}{c|}{ OLI Values } \\
\hline $\begin{array}{c}\text { Run } \\
\text { Number }\end{array}$ & $\begin{array}{c}\text { Acid } \\
\text { Volume }\end{array}$ & $\begin{array}{c}\text { Free OH } \\
\text { Sample } \\
\text { Result }\end{array}$ & $\begin{array}{c}\text { Calculated } \\
\mathrm{pH}\end{array}$ & $\begin{array}{c}\mathrm{pH} \\
\text { Paper }\end{array}$ & $\begin{array}{c}\text { ISFET } \\
\mathrm{probe} \\
\mathrm{pH}\end{array}$ & $\begin{array}{c}\text { OLI Free } \\
\text { OH }\end{array}$ & $\begin{array}{c}\text { OLI } \\
\text { Density }\end{array}$ & $\begin{array}{c}\text { OLI } \\
\text { Free } \\
\text { OH }\end{array}$ & OLI pH & $\begin{array}{c}\text { Calculated pH } \\
\text { from OLI Free } \\
\text { OH value }\end{array}$ \\
\hline UF-1-8 & 96,000 & $<0.002$ & $<11.3$ & 9.5 & 9.54 & 0.00178 & 1.0714 & 0.083 & 12.99 & 12.92 \\
\hline UF-1-6 & 72,000 & 0.036 & 12.56 & 12.5 & 12.45 & 0.00460 & 1.0758 & 0.215 & 13.4 & 13.33 \\
\hline UF-1-4 & 48,000 & 0.076 & 12.88 & 13.3 & 13.16 & 0.00800 & 1.0813 & 0.376 & 13.7 & 13.58 \\
\hline UF-1-3 & 36,000 & 0.124 & 13.09 & 13.3 & 13.11 & 0.00828 & 1.0664 & 0.384 & 13.6 & 13.58 \\
\hline & & & & & & & & & & \\
\hline RUF-1 & 40,000 & 0.063 & 12.80 & 12.5 & 12.82 & 0.00552 & 1.0674 & 0.256 & 13.47 & 13.41 \\
\hline RUF-3 & 40,000 & $<0.002$ & $<11.3$ & 11.5 & 11.57 & 0.00448 & 1.0783 & 0.210 & 13.41 & 13.32 \\
\hline
\end{tabular}

\footnotetext{
${ }^{14}$ Reference mixing study
} 


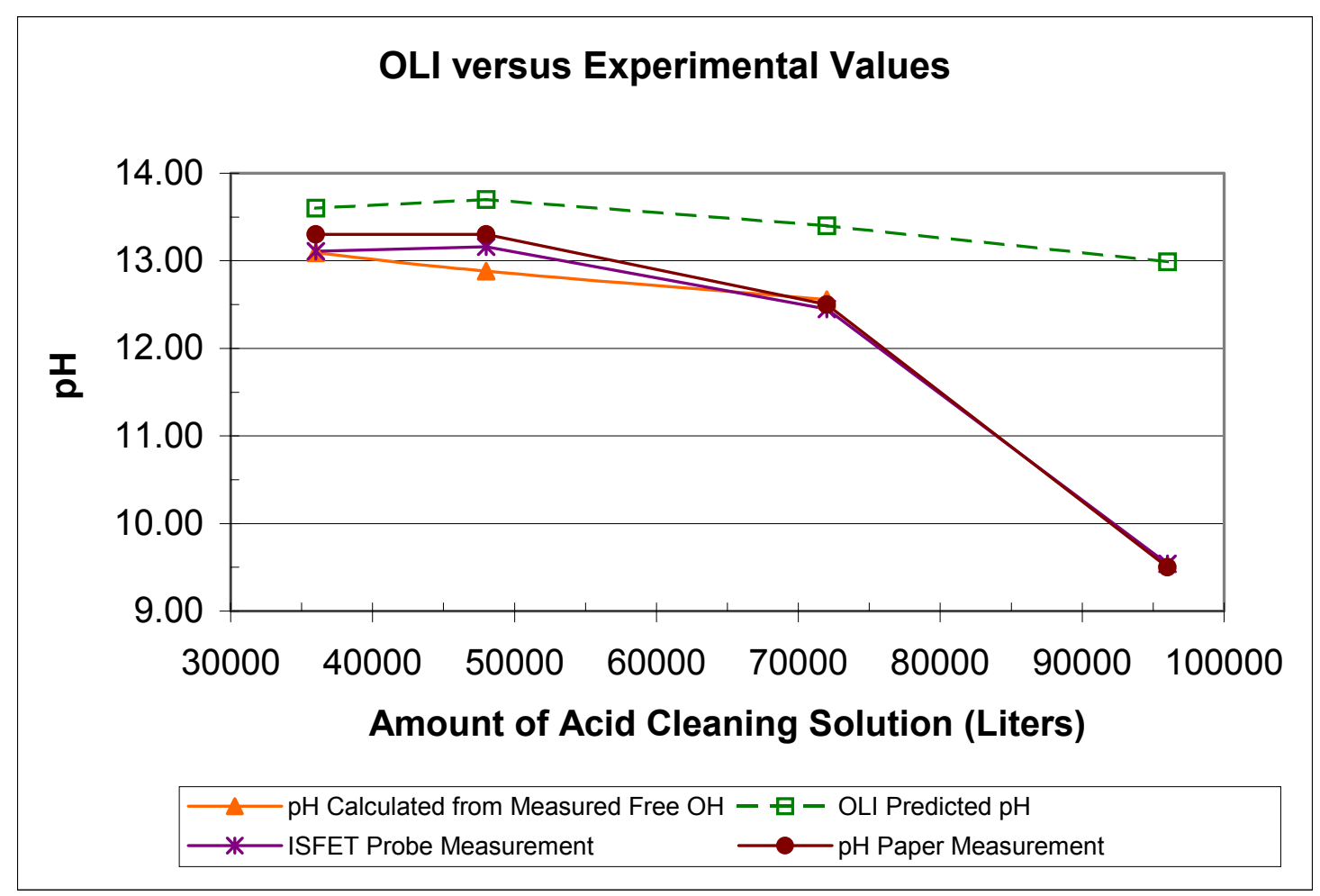

Figure D- 2. Results for OLI pH Predictions versus Experimental Results

The results of the measurement of the amount of aluminum that is soluble are shown in Table D-3. The experimental results for soluble aluminum were above the total aluminum results for three of the samples and the total aluminum results for run UF-1-8 is much higher than expected (aluminum concentration should be less than UF-1-6). The sample results were deemed inadequate to validate the model.

One other factor impacts the validation of the model based on soluble aluminum to total aluminum ratios. The filter installed in the model to allow determination of the amount of solids predicted by the model from the acid cleaning addition removes a significant amount of the aluminum in the input streams. The model would have to be re-run without the filter to allow a comparison to the experimental results. Given the inadequacies in the sample results, the additional model runs were not conducted.

Table D- 3. Soluble/Insoluble Ratio Results

\begin{tabular}{|c|c|c|c|c|c|c|}
\hline $\begin{array}{c}\text { Run } \\
\text { Number }\end{array}$ & $\begin{array}{c}\text { Soluble } \\
\mathrm{Al}\end{array}$ & Total Al & $\begin{array}{c}\text { Soluble } \\
\text { Ratio }\end{array}$ & $\begin{array}{c}\text { OLI } \\
\text { Soluble Al }\end{array}$ & OLI Insoluble & OLI Soluble Ratio \\
\hline $\mathrm{mg} / \mathrm{L}$ & $\mathrm{mg} / \mathrm{L}$ & $\%$ & grams & grams & $\%$ \\
\hline UF-1-8 & 42.7 & 4500 & 0.95 & 0.026 & 0.179 & 12.6 \\
\hline UF-1-6 & 1310 & 2000 & 65.5 & 0.064 & 0.142 & 31.2 \\
\hline UF-1-4 & 5120 & 2280 & $>100$ & 0.107 & 0.100 & 51.7 \\
\hline UF-1-3 & 4820 & 4260 & $>100$ & 0.121 & 0.086 & 58.3 \\
\hline RUF-1 & 2910 & 2860 & $>100$ & 0.119 & 0.191 & 38.4 \\
\hline RUF-3 & 501 & 3330 & 15.0 & 0.104 & 0.227 & 31.5 \\
\hline
\end{tabular}




\section{Appendix E. Evaporation Photographs}

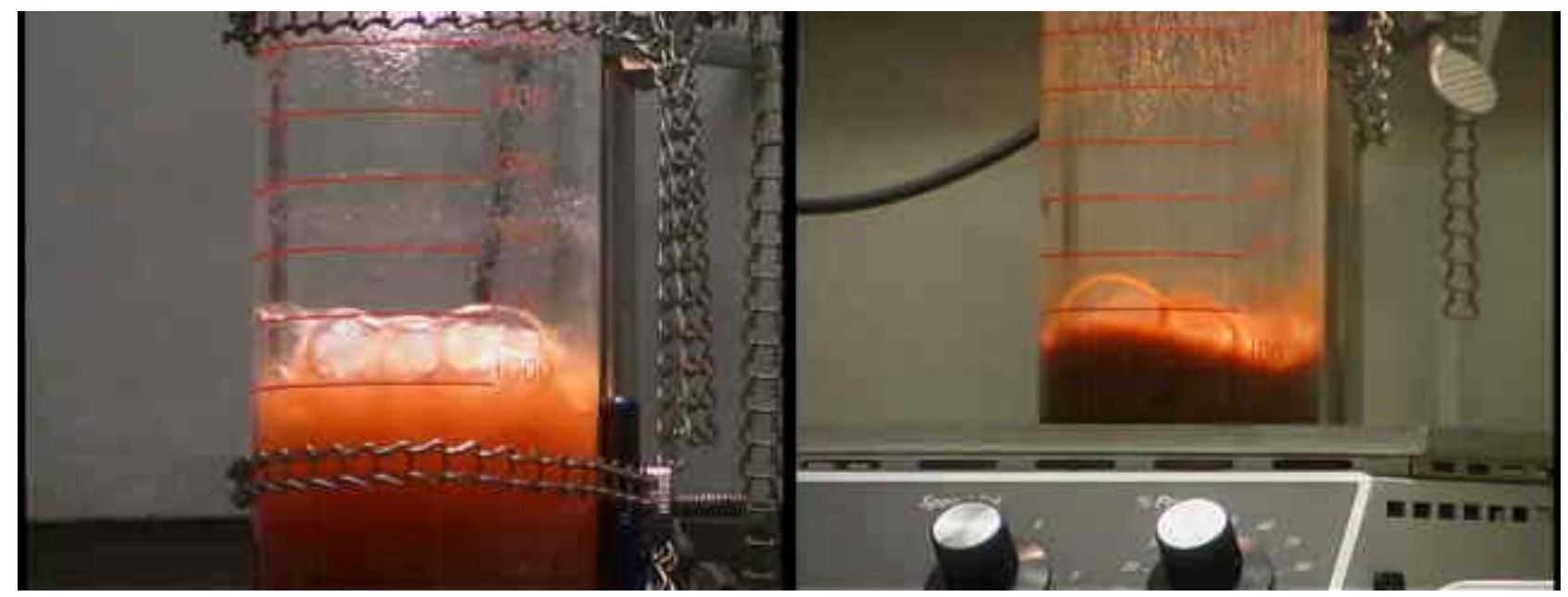

Figure E- 1. Evaporation of Envelope A UF Recycle

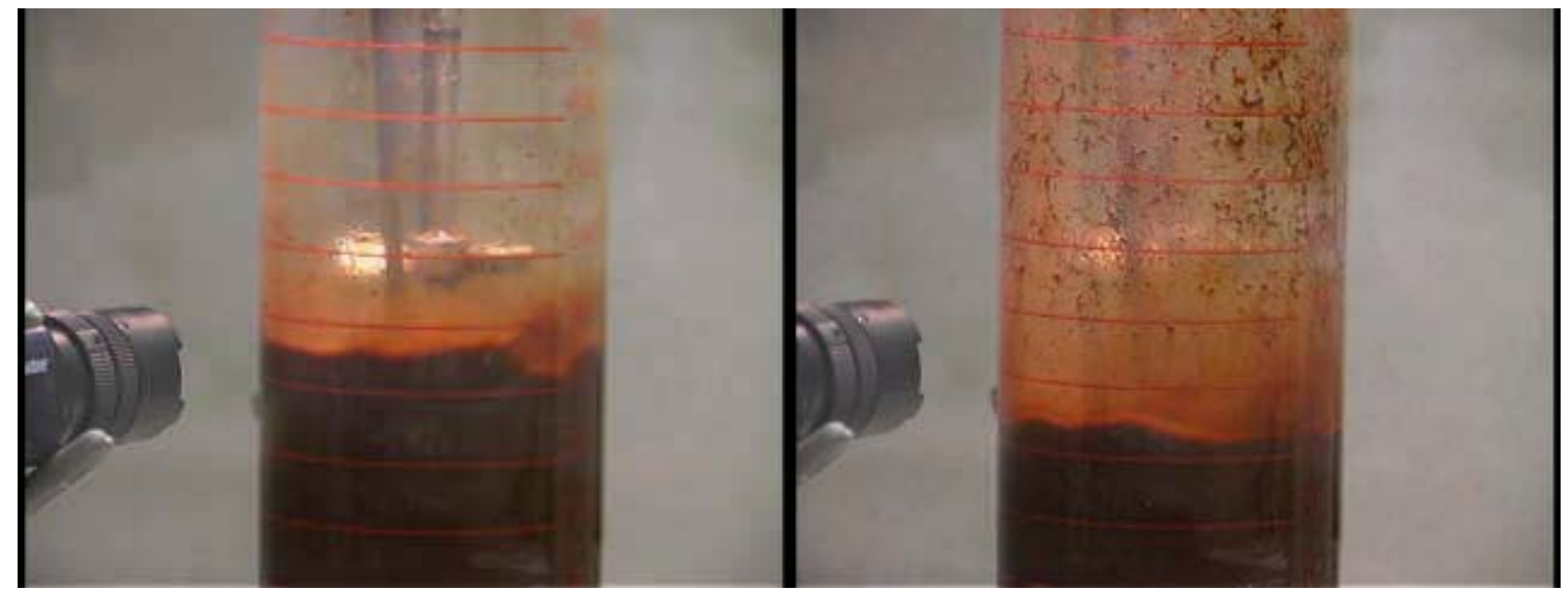

Figure E- 2. Evaporation of AZ-102 w/ 3.5\% Initial Insoluble Solids 


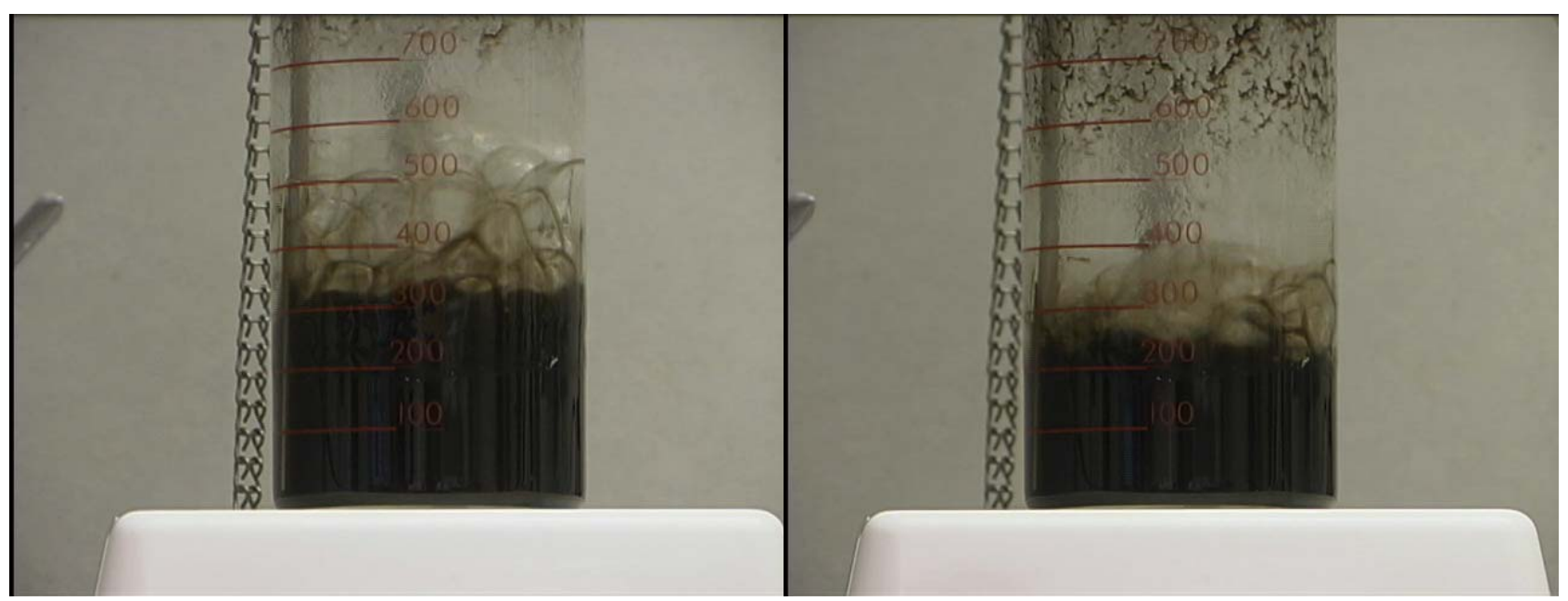

Figure E- 3. Evaporation of Envelope C UF Recycle 